\title{
INFLUÊNCIA DO EDTA, LASER DE ND:YAG E DA COMBINAÇÃO DE AMBOS SOBRE A DENTINA RADICULAR E NA OBTURAÇÃO DE CANAIS LATERAIS.
}

FERNANDA GOMES DE MORAES

Dissertação apresentada à Faculdade de Odontologia de Bauru da Universidade de São Paulo, como parte dos requisitos para obtenção do título de Mestre em Odontologia, área de Endodontia.

(Edição Revisada)

BAURU

2003 


\section{INFLUÊNCIA DO EDTA, LASER DE ND:YAG E DA COMBINAÇÃO DE AMBOS SOBRE A DENTINA RADICULAR E NA OBTURAÇÃO DE CANAIS LATERAIS.}

\section{FERNANDA GOMES DE MORAES}

Dissertação apresentada à Faculdade de Odontologia de Bauru da Universidade de São Paulo, como parte dos requisitos para obtenção do título de Mestre em Odontologia, área de Endodontia.

(Edição Revisada)

Orientador: Prof. Dr. Clovis Monteiro Bramante

BAURU

2003 


\begin{tabular}{|l}
\multicolumn{1}{|c|}{ Moraes, Fernanda Gomes } \\
M792i Influência do EDTA, do laser de Nd:YAG e da \\
combinação de ambos sobre a dentina radicular e na \\
obturação de canais laterais. - Bauru, 2003. \\
103 p.: il.; 30cm \\
Dissertação. (Mestrado) -- Faculdade de \\
Odontologia de Bauru. Universidade de São Paulo. \\
Orientador: Prof. Dr. Clovis Monteiro Bramante
\end{tabular}

Autorizo, exclusivamente para fins acadêmicos e científicos, a reprodução total ou parcial desta dissertação/tese, por processos fotocopiadores e outros meios eletrônicos.

Assinatura

Comitê de Ética da FOB

№ do Protocolo: Proc. № 083/2002

Data de aprovação: 28/ 08/ 2002 


\section{FERNANDA GOMES DE MORAES}

03 de janeiro de1977

Bauru - SP

Ivaldo Gomes de Moraes

Maria do Carmo de Oliveira Moraes

$1996-1999$

$2001-2003$

Associações
Nascimento

Filiação

Curso de Odontologia

Universidade do Sagrado

Coração - USC

Curso de Pós-Graduação em Endodontia, em nível de mestrado, na Faculdade de Odontologia de Bauru da Universidade de São Paulo

$\mathrm{CRO}$ - Conselho Regional de Odontologia - SP 
Uma mensagem especial:

"...a vida de cada um de nós é como o texto de um livro, que leva nosso nome e do qual devemos ser seu principal protagonista, sua figura proeminente, se não queremos nos ver deslocados para segundo plano e, pior ainda, por haver desempenhado nele um papel de pouca significação. Para conseguir isso, não deveremos deixar que nossa vida corra ao acaso pelos escorregadios caminhos da inconsciência. Ao contrário, temos de vivê-la guiados sempre por nossa inteligência, em lúcidos estados de consciência, para que não passe em branco um só dia. Deste modo a vida se enriquece, porque incita a superar nossa concepção sobre a mesma. O segredo consiste em preparar com antecipação os dias futuros, semeando hoje o que anelamos colher amanhã. Desse modo desfrutamos já, adiantadamente, do prazer que nos proporciona a gestação consciente do nosso futuro. Se conseguirmos fazer disto o objetivo principal e permanente de nossa vida, nos haveremos convertido em artífices de nossa própria felicidade..."

Trecho do Livro "O Senhor de Sándara"

Carlos Bernardo Gonzalez Pecotche 


\section{DEDICATÓRIA:}

Aos meus pais Ivaldo e Maria do Carmo, que são os responsáveis por eu ter chegado até aqui, sempre incentivando-me, orientandome e, acima de tudo, ofertando-me tanto amor, que não teria como descrever nessas páginas.

Aos meus irmãos Renata e Guilherme, pelo convívio, amizade e amor fraterno.

Aos meus avós, já falecidos, Nabor Benedito de Oliveira e Tibúrcio Gomes de Moraes, pelo exemplo de vida e ensinamentos deixados. A onde estiverem, tenho certeza de que estão felizes por esta minha conquista.

Ao meu amigo de graduação José Ricardo, que tinha como sonho cursar o mestrado em Endodontia, mas Deus com os seus desígnios, achou por bem retirá-lo de nosso convívio mais cedo. Sei que ele está feliz e satisfeito com esta vitória.

“A glória da amizade não é a mão estendida, nem o sorriso carinhoso, nem mesmo a delícia da companhia. É a inspiração espiritual que vem quando você descobre que alguém acredita e confia em você." Ralph Waldo Emerson 
Ao Prof. Dr. Clovis Monteiro Bramante, pela transmissão dos conhecimentos e pela orientação deste trabalho de forma sempre firme e esclarecedora. Por tudo aquilo que me brindou.

Meus sinceros agradecimentos

"Feliz aquele que transfere o que sabe e aprende o que ensina." Cora Coralina 


\section{AGRADECIMENTOS ESPECIAIS:}

A Deus ser supremo que está junto de mim inspirando-me e dando inteligência e força para superar qualquer obstáculo.

Ao meu pai Ivaldo que sempre me deu muito amor e carinho, incentivando-me e apoiando-me em tudo, não medindo esforços para ver-me feliz. Um exemplo de homem, pai, marido e profissional. Soube ser pai em certas horas e professor em outras. Meu eterno orientador ao qual sempre pedirei ajuda e sei que sempre serei socorrida. Seu caráter e sua humildade são algo que sempre tentarei imitar.

À minha mãe Maria do Carmo por todo incentivo, doação total por mim e por meus irmãos e pelo amor que a mim dedica, com muita paciência e carinho.

À minha querida irmã Renata, por ser minha verdadeira amiga, por torcer por mim, sempre, tanto no lado pessoal como profissional.

Ao meu querido irmão Guilherme, pelas brincadeiras e momentos engraçados e alegres que passamos juntos.

Ao Marco Antônio (Sal), pela amizade. Considero-o mais do que um amigo é meu irmão mais velho que sempre está à disposição colaborando comigo e orientando-me sempre que preciso. Não tenho palavras para agradecer tudo o que fez e faz por mim. Só peço a Deus que proteja e o ilumine sempre e que continue sendo essa pessoa maravilhosa, humilde e inteligente que sempre foi. 
À Daniela, pela ajuda na realização deste trabalho, pela paciência e principalmente pela amizade e conselhos sempre sábios.

Aos professores do departamento de Endodontia Alceu Berbert, Clovis Monteiro Bramante, Ivaldo Gomes de Moraes, Norberti Bernardinelli e Roberto Brandão Garcia, pela convivência e pelos ensinamentos. Profissionais brilhantes que sempre respeitei e admirei.

Aos professores Silvio Fraga, Milton Kuga, Marco Antônio, José Carlos Yamashita e Eliane, pelos ensinamentos endodônticos transmitidos durante o meu curso de graduação, responsáveis pelos meus primeiros passos na endodontia, e pela amizade.

\section{A todos os professores da Pós-Graduação.}

À UNESP de São José dos Campos, em nome da Professora Doutora Márcia Valera, pelo empréstimo do aparelho de laser, indispensável para a realização deste trabalho.

Ao Professor José Humberto Dias da Silva, professor de física da UNESP de Bauru, pelas informações físicas sobre o laser.

Ao Professor Doutor Marco Antônio Húngaro Duarte pela realização dos cálculos estatísticos.

Aos colegas de pós - graduação Everdan, Giovana, Jazzmina, Leandro, Maristela, Renato, Rodrigo e Sérgio, pela amizade e convívio durante esses dois anos de curso. 
Aos colegas do "mestrado antigo" Graziela, José Francisco, Juan, Silvana, Sônia, Ulisses, Vítor e Viviane, pela amizade nascida durante a realização desse trabalho.

Aos colegas do doutorado Carlos Henrique, Carlos Herrero, Christian, Fabiana, Flaviana, Luciana, Patrícia, Sérgio e Vânia pelas experiências compartilhadas durante o curso de pós -graduação.

Aos colegas de pós - graduação de outros cursos pela amizade e convívio.

Às minhas amigas da graduação Thatiane, Karita, Renata e Luciana, que, apesar da distância física, sempre me deram força para realização deste trabalho.

Às minhas amigas Josiane, Nicole e Silvana, pela amizade, pelo carinho e todo apoio estando do meu lado em todos os momentos, felizes ou tristes. Vocês foram fundamentais para minha conquista.

Ao amigo Leandro pela amizade e pela troca de conhecimentos e ajuda na realização deste trabalho.

Ao meu amigo Renato pela amizade, pela troca de experiências e pelos ensinamentos transmitidos durante cada trabalho realizado.

Ao meu querido amigo Everdan, o qual considero um irmão, pela amizade, pelo carinho, pela força e por confiar no meu potencial. Agradeço aos seus familiares tia Rita, seu Fermiano, Gonçalo e Maria Amélia, pela amizade e carinho com que sempre me trataram. 
Ao Cadú e a Cleide pela amizade, companheirismo e incentivo.

Ao Christian pela amizade e ajuda desde a época da minha graduação.

À Gisele pela versão para o inglês do resumo e pela amizade de muito tempo.

Aos funcionários do departamento de Endodontia Sueli, Neide, Edimauro e Patrícia pela atenção, ajudando-me sempre em tudo o que eu precisei e pela amizade e convivência de sempre.

Aos funcionários da biblioteca, principalmente Ademir, Rita e César pela ajuda no levantamento bibliográfico.

À Valéria pela correção das referências bibliográficas.

Aos funcionários do xerox, principalmente Salvador e Lígia pela disposição em sempre ajudar.

Aos funcionários da Pós-graduação, principalmente Aurélio pelas informações e atenção prestadas para realização deste trabalho.

À Ana e Cleusa, funcionárias da clínica de Pósgraduação, pela ajuda durante os períodos de clínica.

À Daniela e Tânia do departamento de histologia pela amizade e pelos ensinamentos da técnica histológica, sempre com muita paciência. 
Aos funcionários do Setor de Urgência pela amizade.

À Faculdade de Odontologia de Bauru, em nome da sua Diretora Professora Doutora Maria Fidela de Lima Navarro.

À comissão de pós-graduação, por meio de seu presidente o Professor Doutor José Carlos Pereira.

À CNPq, pelo recursos financeiros.

E a toda as pessoas que direta ou indiretamente colaboraram com a realização desse trabalho,

Meus mais sinceros agradecimentos 


\section{SUMÁRIO}

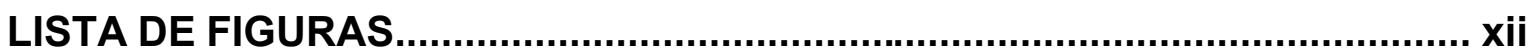

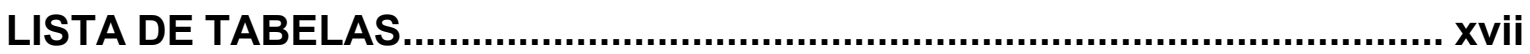

LISTA DE ABREVIATURAS E SÍMBOLOS.................................................. xviii

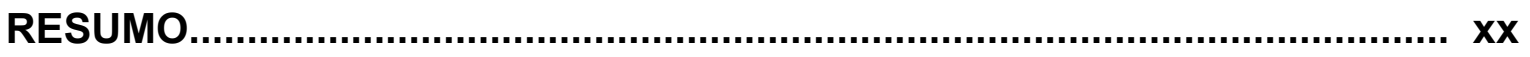

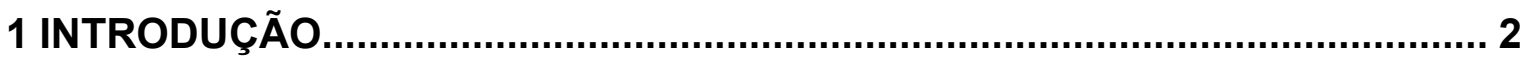

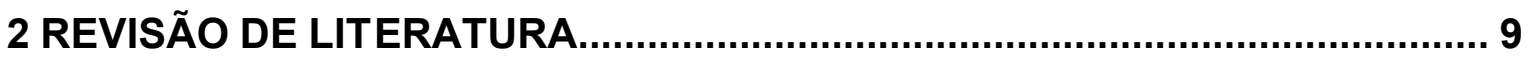

2.1 Efeito do laser de Nd:YAG sobre a estrutura da dentina.................................

2.2 Uso do EDTA na Endodontia como agente de limpeza................................. 22

2.3 A presença e a importância dos canais laterais..............................................32

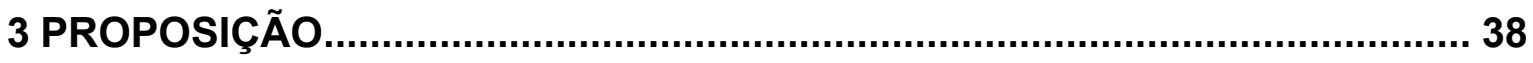

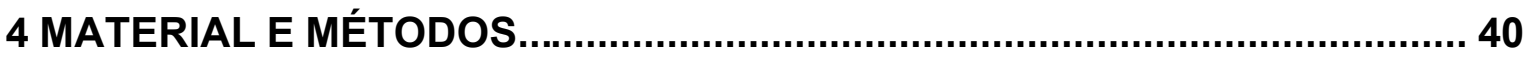

5 RESULTADOS

6 DISCUSSÃO

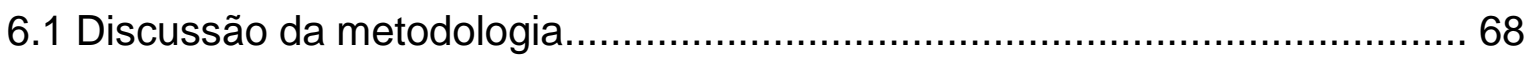

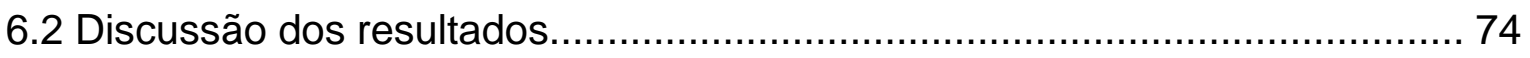

7 CONCLUSÕES

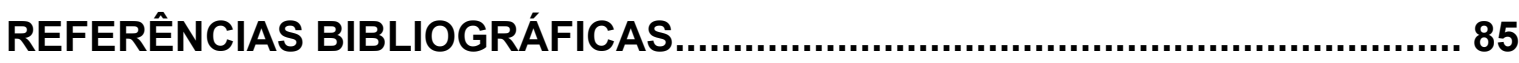

ABSTRACT

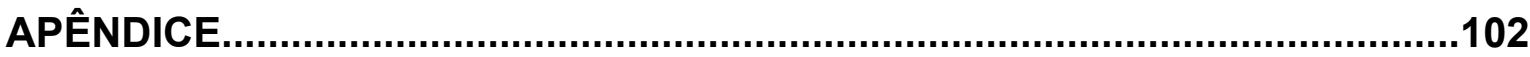




\section{LISTA DE FIGURAS}

FIGURA 1 - Lima do tipo K no 10 preparada, no adaptador.

FIGURA 2- "Alargador" acoplado no contra-ângulo.

FIGURA 3- Confecção do canal lateral

FIGURA 4- Lima do tipo $\mathrm{K}$ nํ 10 posicionada no canal lateral artificial já confeccionado. 42

FIGURA 5- Aparelho de laser de Nd:YAG. 45

FIGURA 6- Imagem radiográfica que representa o escore 0 .47

FIGURA 7- Imagem radiográfica que representa o escore 0,5. 47

FIGURA 8- Imagem radiográfica que representa o escore 1 47

FIGURA 9- Imagem radiográfica que representa o escore 2 48

FIGURA 10- Imagem radiográfica que representa o escore 3. 48 
FIGURA 11- Gráfico representativo dos postos médios obtidos em função dos escores atribuídos a obturação ou não dos canais laterais, independentemente do terço analisado. .56

FIGURA 12- Gráfico representativo dos postos médios obtidos em função dos escores atribuídos a obturação ou não dos canais laterais, dos terços: cervical, médio e apical respectivamente. .56

FIGURA 13- Embocadura do canal lateral artificial no terço cervical - espécime pertencente ao Grupo 1 57

FIGURA 14- Parte da parede do canal localizada no terço cervical - espécime pertencente ao Grupo 1 58

FIGURA 15- Embocadura do canal lateral artificial no terço médio - espécime pertencente ao Grupo 1 58

FIGURA 16- Parte da parede do canal localizada no terço médio - espécime pertencente ao Grupo 1 59

FIGURA 17- Embocadura do canal lateral artificial no terço apical - espécime pertencente ao Grupo 1 59 
FIGURA 18- Parte da parede do canal localizada no terço apical - espécime pertencente ao Grupo 1 60

FIGURA 19- Embocadura do canal lateral artificial no terço cervical - espécime pertencente ao Grupo 2. 60

FIGURA 20- Parte da parede do canal localizada no terço cervical - espécime pertencente ao Grupo 2 61

FIGURA 21- Embocadura do canal lateral artificial no terço médio - espécime pertencente ao Grupo 2 61

FIGURA 22- Parte da parede localizada no terço médio - espécime pertencente ao Grupo 2 62

FIGURA 23- Embocadura do canal lateral artificial no terço apical - espécime pertencente ao Grupo 2 62

FIGURA 24- Parte da parede localizada no terço apical - espécime pertencente ao Grupo 2 63 
FIGURA 25- Embocadura do canal lateral artificial no terço cervical - espécime pertencente ao Grupo 3. 63

FIGURA 26- Parte da parede localizada no terço cervical - espécime pertencente ao Grupo 3 64

FIGURA 27- Embocadura do canal lateral artificial no terço médio - espécime pertencente ao Grupo 3. 64

FIGURA 28- Parte da parede do canal localizada no terço médio - espécime pertencente ao Grupo 3 65

FIGURA 29- Embocadura do canal lateral artificial no terço apical - espécime pertencente ao Grupo 3 65

FIGURA 30- Parte da parede do canal localizada no terço apical - espécime pertencente ao Grupo 3 66

FIGURA 31- Embocadura do canal lateral artificial no localizada terço cervical. 76 
FIGURA 32- Embocadura do canal lateral artificial localizada no terço apical. 76

FIGURA 33- Embocadura do canal lateral artificial localizada no terço apical. 77

FIGURA 34- Parte da parede do canal localizada no terço médio de um dente escuro - espécime pertencente ao Grupo 3. 79

FIGURA 35- Embocadura do canal lateral artificial no terço médio de um dente escuro - espécime pertencente ao Grupo 3 79 


\section{LISTA DE TABELAS}

TABELA 1- Valores dos escores referentes ao Grupo I .51

TABELA 2- Valores dos escores referentes ao Grupo II. .52

TABELA 3- Valores dos escores referentes ao Grupo III .53

TABELA 4 Soma dos Postos Médios em função dos escores atribuídos aos canais laterais artificiais obturados ou não, de acordo com o tratamento efetuado nas paredes dos canais radiculares (grupos experimentais), nos três terços radiculares. 54

TABELA 5- Soma dos Postos Médios, em função dos escores atribuídos aos canais artificiais obturados ou não de acordo com os tratamentos efetuados nas paredes dos canais radiculares (grupos experimentais), apenas no terço cervical. 54

TABELA 6- Soma dos Postos Médios, em função dos escores atribuídos aos canais artificiais obturados ou não de acordo com os tratamentos efetuados nas paredes dos canais radiculares (grupos experimentais), apenas no terço médio. 55

TABELA 7- Soma dos Postos Médios, em função dos escores atribuídos aos canais artificiais obturados ou não de acordo com os tratamentos efetuados nas paredes dos canais radiculares (grupos experimentais), apenas no terço apical. .55 
$\mu \mathrm{m}$

Micrometros

EDTA Ácido etileno diamino tetracético $\%$. Porcentagem $\mathrm{pH}$ Potencial hidrogênico

a.C Antes de Cristo

d. C Depois de Cristo

$\mathrm{Nd}$ Neodímio

YAG Ítrio-aluminio-granada $\mathrm{nm}$. Nanômetros

$\mathrm{CO}_{2}$ Gás carbônico W Watts p.p.s Pulso por segundo ms. Milisegundos M.E.V Microscópio eletrônico de varredura $\mathrm{Hz}$ Hertz $\mathrm{NaOCl}$ Hipoclorito de sódio mJ. MiliJoule

Ho Holmio $\mathrm{mJ} / \mathrm{p}$ MiliJoule por pulso

Er. Érbio $\mathrm{H}_{2} \mathrm{O}_{2}$ Peróxido de hidrogênio 
$\mathrm{ml}$ Mililitros

N. Normal

no Número

cc. Centímetros cúbicos $\mathrm{X}$ Vezes $>$ Maior que

g. Grama $\mathrm{Ag}\left(\mathrm{NH}_{3}\right)_{2} \mathrm{~F}$. Flureto de Nitrato de Prata 


\section{Resumo:}

Objetivourse avaliar a influência do EDTA, laser de Nd:YAG e da combinação de ambos nas superfícies das paredes dentinárias e na obturação de canais laterais artificiais. Foram utilizados 54 pré-molares inferiores com 1 raiz e 1 canal radicular. Suas coroas foram removidas e três canais laterais artificiais foram confeccionados nos três terços de uma das faces proximais de cada uma dessas raízes com um alargador com diâmetro referente a uma lima do tipo $\mathrm{K}$ número 15. Preparado os canais laterais, os canais principais foram instrumentados com limas do tipo K no terço apical, até a de ํo 40, e com brocas de Gattes Glidden nos terços cervical e médio. A irrigação foi feita com hipoclorito de sódio a $1 \%$ a cada troca de instrumento e uma irrigação final com soro fisiológico. As raízes foram divididas em 3 grupos com 18 raízes em cada um, em função dos tratamentos a que foram submetidas as paredes dos canais: Grupo1 aplicação de EDTA por 5 minutos, agitação com instrumento de memória, irrigação final com soro fisiológico; Grupo 2 - 4 aplicações de laser de Nd:YAG com $15 \mathrm{~Hz}, 100 \mathrm{~mJ}$ e 1,5 Watts com movimentos helicoidais, em cada dente e Grupo 3 - aplicação de EDTA nos moldes do Grupo1 e, após essa etapa, aplicação do laser de Nd:YAG conforme o Grupo 2. Das 18 raízes, 3 foram preparadas para análise ao M.E.V. e as 15 restantes tiveram os canais obturados. A obturação foi feita com guta-percha e cimento AH Plus utilizando a técnica Híbrida de Tagger. Após a obturação foram feitas tomadas radiográficas das raízes para análise da obturação dos canais laterais artificiais. As raízes que foram reservadas para observação ao M.E.V., foram seccionadas longitudinalmente e, então, preparadas para as fotomicrografias onde se procurou evidenciar as embocaduras dos canais laterais e os túbulos dentinários, em cada terço. A análise dos resultados demonstrou não haver diferenças estatisticamente significantes $(p>0,05)$ entre os procedimentos realizados e nem em relação à obturação dos canais laterais artificiais. As fotomicrografias revelaram que as 
embocaduras dos canais laterais artificiais, independentemente dos terços analisados, em alguns casos, foram obliteradas com "smear layer" e não por dentina derretida, e que em alguns casos, o laser foi capaz de derreter dentina e selar os túbulos dentinários. 


\section{1- Introdução}




\section{1- Introdução}

A obturação do sistema de canais radiculares é a etapa que completa os procedimentos clínicos de esvaziamento, ampliação e antissepsia do canal, devendo selar todo o sistema, o mais hermeticamente possível. Esse selamento é obtido por meio dos materiais obturadores, utilizandose das mais variadas técnicas de obturação.

Segundo COHEN $^{23}$, DE DEUS ${ }^{27}$ e LEONARDO; LEAL ${ }^{61}$, a obturação adequada deve ser compacta e completa, realizada com materiais inertes ou antissépticos e capazes de assegurar um selamento hermético.

Já em 1964, GROSSMAN; SHEPARD; PEARSON ${ }^{46}$ afirmaram que as causas dos insucessos nos tratamentos de canais radiculares eram resultantes de obturações permeáveis e insatisfatórias.

Uma obturação perfeita deve cumprir com a seguinte tríade: confinamento, ocupação de espaço e antissepsia. A antissepsia está na dependência das propriedades biológicas (bactericida ou bacteriostática) dos materiais utilizados. Normalmente, os cimentos endodônticos possuem certo poder antisséptico. Já as outras duas dependem das propriedades físicas dos mesmos, como escoamento (fluidez), inalterabilidade dimensional, etc; bem como do poder de selamento propiciado pela técnica de obturação utilizada.

Anatomicamente, o sistema de canais radiculares é composto, além do canal principal, de outros canais menores que, pela posição que ocupam e, mesmo pelos seus diâmetros, não permitem o acesso direto a eles, durante o preparo biomecânico.

Assim, esses canais, podem se tornar causadores de insucessos endodônticos por abrigarem restos necróticos, microrganismos e/ou exsudato. XU; ZHANG ${ }^{102}$ afirmaram que o tecido e bactérias remanescentes nos canais laterais e acessórios podem ser uma fonte de infecção. Segundo WEINE ${ }^{95}$, o conteúdo dos canais laterais quando inflamado e/ou infectado pode causar dor durante o tratamento endodôntico, podem também simular doenças periodontais; além disso, o número de canais laterais obturados é menor do que a sua 
freqüência de existência. Por esses motivos, torna-se imperativo que canais laterais sejam esvaziados pelas manobras realizadas durante 0 preparo biomecânico, para que ocorra seus preenchimentos com materiais obturadores. $\mathrm{O}$ preenchimento pode ser feito apenas por cimento ou por esse e guta-percha, dependendo da técnica de obturação utilizada. É interessante lembrar que o cimento obturador deve ser manipulado na consistência ideal e que sua capacidade de escoamento permita a sua penetração nos mais íntimos locais do sistema de canais radiculares. Técnicas que plastificam a guta-percha possibilitam que a mesma, também, possa penetrar nessas ramificações.

Os pequenos canais que permitem a comunicação do canal principal com o periodonto, se não forem obturados poderão causar a perpetuação de uma lesão, levando o tratamento endodôntico ao fracasso. ${ }^{102}$

Portanto, canais laterais ou até mesmo os secundários, (Classificação de PUCCI; REIG ${ }^{82}$ ) os quais estabelecem a comunicação do canal principal com o periodonto lateral e apical, respectivamente, devem ser obturados, também.

Os túbulos dentinários também são entidades importantes e devem ser selados, pois podem abrigar bactérias. RIBEIRO; CONSOLARO ${ }^{83}$ encontraram bactérias Gram-positivas e principalmente Gram-negativas, localizadas, na maioria das vezes, nos terços médio e apical, atingindo camadas mais internas da dentina, em dentes com necrose pulpar. Bactérias também foram observadas no lume de canais acessórios, bem como aderidas às suas paredes, coincidindo com os resultados de $\mathrm{NAIR}^{74}$, que também detectou bacilos Gram-positivos no interior de canais acessórios, relacionando essa presença à persistência de lesões inflamatórias após o tratamento endodôntico. LOVE ${ }^{64}$ observou a presença de bactérias nos túbulos dentinários à profundidade de 60 $\mu \mathrm{m}$, no terço apical.

A obturação perfeita se faz importante para que o material possa selar os túbulos dentinários confinando as bactérias no interior da massa dentinária. 
Durante a instrumentação há formação de uma camada amorfa e irregular denominada "smear layer". Ela é formada por raspas de dentina contaminadas ou não e por restos pulpares que podem obliterar os túbulos dentinários e impedir uma adequada obturação dos canais laterais e acessórios, bem como impedir o imbricamento de cimento nos túbulos dentinários. Por essas razões a sua remoção se faz necessária.

Essa remoção pode ser feita utilizando-se algumas substâncias. Uma delas, e já consagrada, é o EDTA. Introduzido na endodontia por OSTBY ${ }^{79}$, em 1957, sob a forma de solução aquosa a 15,5\% e pH 7,3, ele é o ácido etileno diamino tetracético trissódico. É um quelante que pode facilitar a instrumentação de canais atrésicos, pois, tem a capacidade de desmineralizar a dentina por meio de uma união estável com íons cálcio. ${ }^{79}$

A remoção da "smear layer" expõe os túbulos dentinários permitindo a ação de curativos de demora, utilizados entre as sessões

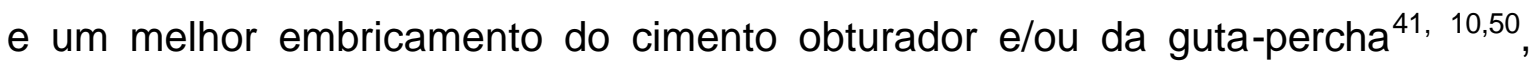
durante a obturação.

Consagrada entre os endodontistas, desde a sua introdução por CALLAHAM ${ }^{16}$, em 1914, a técnica da condensação lateral, para obturação de canais radiculares, cumpre, em parte, com os requisitos para um bom selamento. Entretanto, a obturação das ramificações está sujeita apenas ao cimento obturador, já que a guta-percha não é plastificada.

Com o objetivo de melhorar a capacidade seladora das obturações, em 1967, SCHILDER ${ }^{86}$ introduziu a técnica da condensação vertical da guta-percha aquecida, relatando a ocorrência de uma grande porcentagem de obturação das ramificações dos canais.

Com o mesmo intuito, novas técnicas foram propostas, outras aperfeiçoadas, sempre objetivando a obturação compacta e hermética do sistema de canais radiculares.

MC SPADDEN ${ }^{66}$, em 1978, introduziu a compactação termomecânica rotatória. Os compactadores eram acionados no interior dos canais radiculares criando um calor friccional, plastificando os cones de guta- 
percha, forçando o material lateral e apicalmente, obturando o sistema de canais radiculares. Suas vantagens são: redução do tempo de obturação e da fadiga do operador e o maior preenchimento das irregularidades do canal. Em 1984, TAGGER $^{89}$ modificou esta técnica associando a condensação lateral no terço apical, denominando-a de Híbrida de Tagger.

Além do avanço nas técnicas de obturação, com o desenvolvimento tecnológico, o laser se tornou um meio auxiliar para os cirurgiões-dentistas.

A palavra laser é muito antiga, já data desde a civilização Greco-Romana no século 6 a.C. Era o nome dado a uma planta da família dos Umbelliferae, apreciada na culinária, curava doenças infecciosas e era considerada um antídoto contra veneno de cobras e de escorpiões, mas ela foi extinta no século $2 \mathrm{~d}$. C., devido à sua grande procura. ${ }^{31}$

$\mathrm{Na}$ atualidade, a palavra laser nada mais é do que o acrônimo de Light Amplification by Stimulated Emission of Radiation (Amplificação da luz por emissão estimulada de radiação), desenvolvida por físicos. O primeiro passo para sua criação foi dado por Albert Einstein, em 1917, que descreveu a emissão estimulada. Porém, foi somente em 1960 que MAIMAN (apud BRUGNERA) criou o primeiro laser que era de rubi. ${ }^{14}$ ADRIAN; BERNIER; SPRANGUE ${ }^{1}$, em 1971, usaram o laser de rubi em polpa, para determinar a quantidade mínima de energia que poderia ser usada para que não houvesse alterações histológicas.

Hoje são apresentados vários tipos de laser, os quais recebem o nome de acordo com o elemento químico ou molécula química que compõe o meio ativo, que pode ser gasoso, sólido ou líquido. ${ }^{31}$

Todavia, independente do seu meio ativo, todos têm a mesma característica: é uma energia eletromagnética, de velocidade constante, com monocromaticidade, coerência e colimação, emite o feixe de luz de uma só cor, preciso, focalizado, tamanho e forma constantes. ${ }^{31}$

Os lasers são divididos em lasers de alta ou baixa intensidade. Os de baixa intensidade não têm poder cirúrgico e estão indicados 
para serem usados em: crescimento celular estimulado, regeneração celular, efeito antiinflamatório, redução de edema e revascularização, redução de fibrose na formação tissular, maior atividade tissular, estimulação da função nervosa. ${ }^{31}$

Os de alta intensidade, também são conhecidos como lasers cirúrgicos. Seus efeitos biológicos vão depender da sua interação entre o laser e o tecido. Essa interação depende muito do comprimento de onda, pois dependendo desse comprimento o laser será mais ou menos absorvido pelo tecido em questão. ${ }^{31,58}$

O laser de Nd:YAG é um laser de alta intensidade. Em 1972 WEICHMAN; JOHNSON ${ }^{94}$ utilizaram o laser de Nd:YAG irradiando o forame apical, via canal radicular, notando uma mudança na estrutura da dentina.

Muitos trabalhos mostram a utilização e ação do laser de Nd:YAG em estruturas dentais; pois, dependendo do ajuste de seus parâmetros, resultados interessantes e úteis para o tratamento dentário são conseguidos, como: tratamento de hipersensibilidade dentinária ${ }^{54,60,72}$, pulpotomia ${ }^{54}$, esterilização do canal radicular ${ }^{54}$, limpeza ${ }^{54,85}$, obturação de canais radiculares ${ }^{54}$, apicectomia $^{53}, 54,87,88$, tratamento de fraturas radiculares ${ }^{54}$, esterilização de instrumentos $^{54}$ e modificação da parede dentinária onde a permeabilidade é diminuída devido à fundição da dentina ${ }^{5,25,44,54,62,63,69,80,92,103,104}$. Em alguns trabalhos, o uso de tinta negra é divulgado para se aproveitar da característica do laser em ser melhor absorvido por tecidos com cores e potencializar a sua ação. ${ }^{44}$ 104.

MISERENDINO; LEVY; RIZOIU ${ }^{69}$, em 1995, avaliaram o efeito do laser de Nd:YAG sobre a permeabilidade dentinária e a aparência da dentina parietal do canal principal. Notaram redução na permeabilidade dentinária devido a um depósito de dentina de aparência vitrificada (dentina fundida que se recristalizou) nos túbulos dentinários que, inclusive, obliterava parcialmente a embocadura de canais laterais, podendo impedir sua perfeita obturação, e, talvez, levar a problemas já citados anteriormente.

Se, por um lado, a obliteração das embocaduras dos túbulos dentinários, anteriormente à obturação, pode ser considerada importante 
pelo confinamento de bactérias presentes na massa dentinária, remanescentes às fases anteriores do tratamento endodôntico, por outro, a obliteração, parcial ou total, das embocaduras das ramificações, dificultando ou impedindo a sua completa obturação, não pode ser vista com bons olhos.

Assim, torna-se interessante realizar uma avaliação do uso do laser de Nd:YAG, no interior dos canais radiculares, quanto à sua capacidade de fundir a "smear layer" ou a própria dentina obliterando, assim, as embocaduras de canais laterais, dificultando ou impedindo a obturação dos mesmos. 
2- Revisão de Literatura 


\section{2- Revisão de literatura:}

\section{1- Efeito do laser de Nd:YAG sobre a estrutura da}

dentina

A idéia de laser começou com Albert Einstein, em 1917, que descreveu a emissão estimulada da radiação. Essa emissão pode ser resumida da seguinte forma: um átomo estimulado tem seus elétrons elevados a um nível de energia maior, e quando esses elétrons voltam ao estado de normalidade, é emitida luz. A palavra laser é um acrônimo de Light Amplification by Stimulated Emission of Radiation (Amplificação da luz pela emissão estimulada). Em 1955, GORDON; ZEIGLER; TOWNES (apud BRUGNER) ${ }^{14}$, foram os primeiros a obterem sucesso com emissão de microondas, pela emissão estimulada que era conhecida como Maser. Apenas em 1960 é que Maiman obteve o primeiro raio laser a partir da excitação de um cristal de rubi ${ }^{14}$.

O laser de Nd:YAG foi desenvolvido por JOHNSON(apud BRUGNER) ${ }^{14}$ em 1961, onde íons de neodímio foram integrados a um cristal formado por ítrio, alumínio e granada, que é um cristal sintético com fórmula química $\mathrm{Y}_{3} \mathrm{Al}_{5} \mathrm{O}_{12 .}{ }^{52}$ Esse laser emitido tem comprimento de onda de $1064 \mathrm{~nm}$, é invisível, se encontra abaixo do espectro infravermelho e é absorvido por tecidos pigmentados. $^{52}$

$\mathrm{Na}$ endodontia o laser de Nd:YAG foi usado pela primeira vez por WEICHMAN et al. ${ }^{94}$, em 1972. Utilizando Nd:YAG e o de $\mathrm{CO}_{2}$, variando a potência (de $0,01 \mathrm{~W}$ até $100 \mathrm{~W}$ ), o pulso por segundo (de 1 até 1000 p.p.s.) e 0 tempo de pulso (de 0,01 a $300 \mathrm{~ms}$ ), irradiaram o canal radicular de dentes e analisaram o forame apical. Concluíram que o laser de $\mathrm{CO}_{2}$ foi similar ao laser de Nd:YAG. Observaram que parte da energia do feixe do laser se transforma em calor. A formação de um tampão apical ocorreu com o aumento da potência, inclusive uma mudança estrutural da dentina também aconteceu e, segundo os autores, essa mudança previne a adesão de microrganismos.

A partir daí muitos experimentos foram realizados. 
DEDERICH; ZAKARIASEN; TULIP ${ }^{25}$, em 1984, analisaram a dentina parietal dos canais de dentes onde foi aplicado o laser de Nd:YAG, em diferentes tempos. A análise foi feita em microscópio eletrônico de varredura, e os autores perceberam áreas onde nada aconteceu, áreas onde houve destruição da "smear layer" e áreas onde a dentina se apresentava sem poros, parecendo vidro. Os autores acreditam que, com essas características, a dentina se torne menos permeável.

Um ano após, isto é, em 1985, ZAKARIASEN; DEDERICH; TULIP ${ }^{103}$ após instrumentarem 24 canais radiculares, depositaram, apicalmente, em cada canal, raspas de dentina, fazendo um tampão. Os dentes foram divididos em 4 grupos: Grupo I- não foi usado laser. Nos demais, foi usado o laser de Nd:YAG, variando-se a potência, da seguinte maneira: Grupo IIpotência de 25W, Grupo III- potência de 37W e no Grupo IV - potência de 50W. Quando analisados ao microscópio eletrônico de varredura, observourse, nos canais onde foi usado o laser, que a dentina sofreu uma fusão e depois uma recristalização formando uma massa contínua com graus diferentes dependendo da potência utilizada; em alguns espécimes houve falhas na fusão e observourse a presença de rachaduras devido ao efeito térmico do laser.

As pesquisas com laser na endodontia foram aumentando e, em 1991, KHAYAT et al. ${ }^{53}$ estudaram o efeito do laser de Nd:YAG em dentina através da observação ao M.E.V. Dezoito dentes tiveram os canais instrumentados e obturados e de cada um foram removidos dois milímetros apicais e, em seguida, foram divididos em 2 grupos. Em um dos grupos foi aplicado laser de Nd:YAG na superfície cortada do dente e no outro grupo não. Os resultados mostraram que a aplicação do laser causou a fusão da dentina e sua recristalização, dando uma aparência vitrificada.

LEVY62, em 1992, comparou as características das paredes dentinárias após a instrumentação dos canais radiculares pela técnica de instrumentação "step-back" convencional, seguida da aplicação de laser. Foram utilizados 32 dentes portadores de canais laterais que foram divididos em 2 grupos. No Grupo I foi realizada a instrumentação com limas do tipo K, tendo-se 
como instrumento de memória a lima de número 35 , realizando-se o recuo até o instrumento de número 60. Os canais dos dentes do Grupo II foram instrumentados até a lima número 20 e depois foi aplicado laser até que os canais se alargassem e chegassem ao diâmetro referente ao da lima 35. O laser utilizado foi o de $\mathrm{Nd}$ :YAG com potência de $35 \mathrm{~W}$ e freqüência de $20 \mathrm{~Hz}$. Os canais dos dentes de ambos os grupos foram irrigados com $\mathrm{NaOCl}$ a $2 \%$. No Grupo I notour se a presença de "smear layer" nas paredes dentinárias e os canais laterais tinham suas entradas livres de debris. No Grupo II houve fechamento dos túbulos dentinários causado pela fusão da dentina (principalmente nos terços médio e apical) e as embocaduras dos canais laterais foram seladas pela dentina fundida.

Ainda em 1992, MORLOCK et al. ${ }^{72}$ observaram o efeito do laser de Nd:YAG na superfície radicular externa, quando associado à raspagem e alisamento radicular. Para isso foram usados 18 terceiros molares, sendo que cada espécime tinha, no mínimo, uma superfície radicular externa que era relativamente achatada. Uma área de três milímetros de diâmetro foi contornada com uma broca esférica 1/4, 2 a 3 milímetros apicalmente à junção cemento-esmalte. A superfície do local do tratamento foi umedecida com saliva humana. Os dentes foram divididos em 6 grupos: Grupo I- não foi realizado nenhum tipo de tratamento, Grupo II- foi realizado alisamento com curetas, Grupo III- aplicação do laser com potência de 1,25W e 20 pulsos por segundo; no Grupo IV- foi realizada aplicação do laser com potência de 1,5W e 20 pulsos por segundo, Grupo V- aplicação do laser com os mesmos parâmetros que o Grupo III, porém, acrescentando-se o alisamento radicular como no Grupo II e Grupo VI aplicação do laser com os mesmos parâmetros do Grupo IV complementando com o alisamento radicular, também. Nos Grupos III e IV, observourse que ocorreu fusão e ressolidificação cementária, contudo, esse fenômeno não foi observado nos outros grupos, mesmo naqueles nos quais foram associados os dois tipos de tratamento.

Também, em 1992, STABHOLZ et al. ${ }^{87}$, avaliaram o efeito do laser na permeabilidade da superfície dentinária após apicectomia e retrobturação. Utilizaram 60 dentes unirradiculados que foram divididos em 3 
grupos com 20 dentes cada, sendo que, destes, 10 dentes serviram como controle e os outros 10 como experimentais para cada grupo. Os procedimentos operatórios foram os mesmos para ambos os sub-grupos; o que diferenciava era que o grupo controle não recebia aplicação de laser. Os dentes dos Grupos I e II tiveram os canais instrumentados e obturados, e na seqüência foi realizada a apicectomia removendo-se dois milímetros apicais da raiz de cada dente. Nos dentes do Grupo I foram feitas cavidades do tipo classe I e retrobturadas com amálgama. No Grupo II foi removido os dois milímetros apicais da raiz e não se realizou uma cavidade. No Grupo III os canais não foram instrumentados e nem obturados, apenas realizourse a apicectomia, como nos grupos anteriores, fazendo-se cavidades do tipo classe I que foram retrobturadas com amálgama, também, como no Grupo I. Na superfície apicectomizada dos dentes experimentais de todos os grupos foi aplicado laser de $\mathrm{Nd}$ :YAG da seguinte maneira: No Grupo II foi realizada um aplicação com potência de $3 \mathrm{~W}$, freqüência de $20 \mathrm{~Hz}$ e energia de $150 \mathrm{~mJ}$, nos Grupos I e III foram realizadas duas aplicações, a primeira igual ao do Grupo II e a segunda com potência de1,9 W, freqüência de $20 \mathrm{~Hz}$ e energia de $95 \mathrm{~mJ}$. As superfícies externas de todos os dentes foram impermeabilizadas com exceção das superfícies apicectomizadas e, então os mesmos foram colocados em solução de azul de metileno a 0,5\%, por 48 horas. A penetração do corante foi medida, verificando-se uma infiltração de corante significantemente menor nos dentes onde foi usado o kser; apenas no Grupo II é que não se observou diferença significativa entre o grupo experimental e o controle. Os autores concluíram que o uso do laser de $\mathrm{Nd}$ : YAG diminuiu a permeabilidade da superfície dentinária devido a modificações que o laser causa na dentina.

Em outro experimento, STABHOLZ et al. ${ }^{88}$ ainda em 1992, dividiram 18 dentes em dois grupos. Em ambos os grupos os dentes foram apicectomizados realizando-se, em seguida cavidades classe I. No Grupo I não houve aplicação de laser e no Grupo II foi aplicado laser de Nd:YAG após a confecção da cavidade. O exame ao M.E.V., no Grupo I, demonstrou a presença de "smear layer" intacta e no Grupo II a camada de "smear layer" sofreu uma 
fusão e uma recristalização, tendo esse material aspecto vítreo aparecendo em certas áreas de forma incompleta e descontínua.

BAHCAL et al. ${ }^{6}$, em 1993, compararam a aparência da superfície dentinária do canal radicular após a instrumentação manual com limas do tipo $\mathrm{K}$ e após preparo com laser de Nd:YAG. Os dentes que sofreram instrumentação manual tiveram os canais alargados até obter-se um batente apical com a lima do tipo $\mathrm{K}$ número 40 . Já nos dentes que sofreriam tratamento com laser os canais foram instrumentados manualmente com as limas do tipo $\mathrm{K}$ até a de número 20 e depois alargados com a aplicação do laser até que chegasse ao diâmetro de uma lima do tipo $\mathrm{K}$ número 40 . Ambos os grupos foram irrigados com hipoclorito de sódio a $2,5 \%$. Os resultados não evidenciaram diferenças significativas na aparência dentinária entre os dois grupos. Alguma diferença foi notada em relação ao tamanho das partículas da "smear layer". Isso foi atribuído às propriedades ópticas do laser de Nd:YAG, bem como, à estrutura e à cor da dentina.

Em 1993, GODDIS et al. ${ }^{40}$ avaliaram a ação do laser de Nd:YAG pulsado com $3 \mathrm{~W}$ de potência e de corrente contínua com $20 \mathrm{~W}$ na remoção de tecido necrótico e da "smear layer". Foram utilizados 40 dentes. Dez tiveram os canais instrumentados com limas e irrigados com $\mathrm{NaOCl}$ a $5,25 \%$ (grupo controle). Os trintas dentes restantes sofreram uma combinação de instrumentação e aplicação de laser, sendo 15 dentes para cada tipo de laser (15 com laser de Nd:YAG com corrente contínua e 15 com laser pulsado). Por fim, os dentes foram seccionados vestíbulo-lingualmente e preparados para observação ao M.E.V. No grupo controle foi observado presença de "smear layer", a embocadura de canal lateral rodeada por calcosferitas, sem presença de tecido remanescente e microrganismos. A combinação de instrumentação e aplicação de laser demonstrou ausência de remanescentes de tecido e "smear layer" nas áreas onde o laser entrou em contato com o canal, caso contrário a área permanecia com "smear layer". Os dois sistemas de laser foram eficientes e alterações ocorreram como, por exemplo, derretimento e fusão da dentina. Por 
fim, os autores concluíram que o laser foi eficiente para remoção da "smear layer" e do tecido remanescente.

WHITE et al. ${ }^{97}$, em 1993, avaliaram o limiar de energia capaz de modificar a dentina em função do comprimento de onda, densidade de energia, textura da superfície dentinária e do tipo de laser. Para esse experimento foram utilizados terceiros molares dos quais foram retiradas duas fatias de mais ou menos 3 a 3,5 milímetros de espessura. Para confeccionar essas fatias foram utilizados discos de diferentes granulações para que se conseguisse superfícies dentinárias de diferentes texturas. Nelas foi aplicado EDTA por 2 minutos e, então, foram lavadas com água destilada. Os lasers utilizados foram o de Nd:YAG com dois comprimentos de onda diferentes e o Ho:YAG com um só comprimento de onda. Assim, foram utilizados três comprimentos de ondas, nove níveis de energia por pulso, três diâmetros de fibra ótica, cinco texturas de superfícies, cinco repetições para cada nível de energia, potência variando de 0,3 a 3,0 W e freqüência de 5 a $20 \mathrm{~Hz}$. As fatias, após serem tratadas com os lasers, foram preparadas para observação ao M.E.V. Para cada comprimento de onda notoutse uma energia limiar por pulso diferente: para o comprimento de onda $1,06 \mu \mathrm{m}$ (Nd:YAG) a energia limiar foi de $167 \mathrm{~mJ} / \mathrm{p}$, para $1,32 \mu \mathrm{m}$ (Nd:YAG) foi de $133 \mathrm{~mJ} / \mathrm{p}$

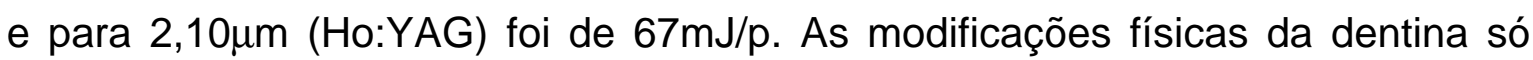
ocorreram com aplicações acima desses dados. Essas modificações foram: fusão e cristalização com parcial fechamento dos túbulos dentinários. As áreas imediatamente adjacentes à aplicação não foram afetadas. As mudanças ocorreram independentemente do diâmetro da fibra ótica. A área modificada tinha aparência polida, houve um aumento na média do número atômico da área modificada devido, provavelmente, à eliminação de colágeno da estrutura dentinária, deixando-a com abundância de fosfato de cálcio. O colágeno sofre uma desnaturação devido à alta temperatura e isso influencia de maneira significante na mudança química sofrida pela matriz dentinária. Acima do limiar de energia as superfícies apareciam ablasionadas com formação de crateras. Essas 
modificações apresentadas na dentina pela energia limiar colabora significantemente para a diminuição da permeabilidade dentinária.

Ainda em 1993, WIGDOR et al. ${ }^{99}$ avaliaram o efeito de três tipos de lasers na dentina e no tecido pulpar de dentes de cães. Os lasers utilizados foram: Er:YAG, $\mathrm{CO}_{2}$ e Nd:YAG. O efeito na dentina foi avaliado por meio do M.E.V. em 4 dentes humanos extraídos e, para avaliação na polpa foram utilizados dois cães dos quais foram escolhidos os dentes incisivos, caninos e pré-molares. Os parâmetros utilizados para aplicação do laser foram: $\mathrm{CO}_{2}-5 \mathrm{~Hz}$, 4W, Nd:YAG- 12,5W com onda contínua e para o laser de Er:YAG- 3Hz energia de 500mJ por pulso. O laser de Er:YAG causou menos efeitos que os outros. Os lasers de $\mathrm{CO}_{2}$ e $\mathrm{Nd}$ YYAG apresentaram resultados semelhantes como fusão da dentina intertubular e, histologicamente, houve uma ruptura na arquitetura normal do tecido, incluindo a desnaturação das camadas de células odontoblásticas, além de um aumento do número de células inflamatórias.

Em 1995, MISERENDINO; LEVY; RIZOIU ${ }^{69}$ avaliaram o efeito da aplicação intracanal do laser de Nd:YAG na permeabilidade dentinária, utilizando-se da infiltração de corante para essa análise, e também na aparência da superfície dentinária das paredes do canal principal, através da análise ao microscópio eletrônico de varredura. Os dentes tiveram seus canais instrumentados pela técnica "step-back" e irrigados com $\mathrm{NaOCl}$ a 2,5\%. Uma metade do número de canais não recebeu nenhum tratamento posterior e na outra metade foi aplicado o laser de Nd:YAG com potência $5 \mathrm{~W}$, freqüência de 50 $\mathrm{Hz}$, com três aplicações de 15 segundos cada. Em seguida, os espécimes foram submetidos à solução corante. Os resultados mostraram uma menor ou nenhuma infiltração do corante no grupo onde foi aplicado o laser. Observaram selamento dos túbulos dentinários com um material parecido com vidro (dentina fundida), que obliterou parcialmente as embocaduras dos canais laterais, quando a análise foi realizada ao microscópio eletrônico de varredura.

SAUNDERS, et al. ${ }^{85}$, em 1995, avaliaram a eficácia do laser de Nd:YAG na limpeza de canais previamente instrumentados, ou de canais sem instrumentação e formação de plugs apicais fundindo alguns materiais. Para 
analisar a limpeza foram utilizados 75 dentes, dos quais 50 tiveram os canais instrumentados, sendo irrigados com $\mathrm{NaOCl}$ a $2 \%$. Esses dentes foram divididos em 5 grupos: Grupo \& sem aplicação de laser, Grupo II- aplicação de laser com potência de 1W, Grupo III- com potência de 1,25W, Grupo IV - com potência de 1,5W e Grupo V-com potência de 1,7W. Em todos os casos onde se aplicou laser foi utilizado 15 p.p.s., com 5 segundos cada aplicação e, todo procedimento durou 60 segundos. Os 25 dentes restantes não sofreram instrumentação e foram divididos em 5 grupos: Grupo ł sem aplicação de laser, Grupo II- aplicação com potência de 1W, Grupo III- com potência de 1,25W, Grupo IV - com potência de 1,5W e Grupo V-com potência de 1,7W, com 15 p.p.s. A aplicação do laser foi feita apenas no terço coronário. Todos os dentes foram seccionados longitudinalmente e preparados para observação ao M.E.V. Mais 115 dentes unirradiculados foram utilizados para analisar a formação de "plugs" apicais. Os dentes foram divididos em grupos onde se mudava o material utilizado para formação do "plug", a energia de potência de aplicação do laser e o tempo de aplicação, no total foram 23 grupos. Esses dentes também foram preparados para observação ao M.E.V. Analisando os resultados, quanto à limpeza, não houve diferença estatisticamente significante entre os grupos dos dentes previamente instrumentados. Nos dentes onde houve a aplicação sem a instrumentação a limpeza foi eficiente. Quanto à formação de "plug", não se observou sua ocorrência com nenhum tipo de material testado independente do tempo e da potência de aplicação.

ANIC, et al. ${ }^{5}$, em 1998, avaliaram a mudança morfológica da superfície dentinária de canais radiculares ou de fatias de dentina preparadas comparando a variação dos ângulos formados entre a fibra ótica de aplicação do laser e a superfície dentinária, no momento da aplicação. Os lasers utilizados foram: de $\mathrm{Nd}$ :YAG, de Argônio e o de $\mathrm{CO}_{2}$. As fibras óticas foram posicionadas paralelas à superfície dentinária, aplicando-se o laser dentro do canal radicular, e perpendicular, aplicando o laser em fatias de dentina preparadas. Quando a fibra foi posicionada paralelamente à superfície dentinária foram produzidos menores efeitos do que quando a fibra foi posicionada perpendicularmente, utilisando-se os 
mesmos parâmetros. O laser de Nd:YAG produziu um efeito maior na superfície radicular em comparação com os outros dois tipos de lasers, mesmo quando aplicado paralelamente à superfície, esse laser produziu crateras na superfície dentinária, cujos fundos foram cobertos com dentina derretida e recristalizada. Os túbulos dentinários da parede da cratera ficaram com os diâmetros menores.

LIU; LIN; LAN ${ }^{63}$, em 1997, avaliaram a profundidade de selamento dos túbulos dentinários após a aplicação do laser de Nd:YAG. Foram preparadas fatias de dentina com três milímetros de espessura e com túbulos dentinários expostos. Essas fatias foram divididas em 3 grupos (A, B e C). Nos Grupos A e B foi aplicado laser com energia de $30 \mathrm{~mJ}$, com 10 p.p.s. com a fibra óptica posicionada perpendicularmente à superfície. As fatias do Grupo B foram congeladas em nitrogênio líquido. No Grupo $C$ as fatias não receberam nenhum tratamento. As fatias de dentina foram preparadas para análise ao M.E.V. Observou-se que nas fatias onde foi aplicado o laser houve o fechamento dos túbulos dentinários com dentina fundida e a profundidade de selamento foi de aproximadamente de $4 \mu \mathrm{m}$ na dentina central e $3 \mu \mathrm{m}$ na dentina marginal. Não houve diferença entre os Grupos A e B.

ZHANG et al. ${ }^{104}$ em 1998, usaram 40 dentes que tiveram os canais instrumentados com lima do tipo K através da técnica "step back", tendo como instrumento de memória a lima de número 40 e foram irrigados com $\mathrm{NaOCl}$ a $5,25 \%$ e $\mathrm{H}_{2} \mathrm{O}_{2}$ a $3 \%$. Em seguida, foram divididos em 4 grupos. O Grupo I serviu como controle. No Grupo II os canais foram irrigados com água destilada e, então, aplicado laser. No Grupo III antes da aplicação do laser, foi colocada tinta preta na parede dentinária do canal em todo o comprimento de trabalho e, no Grupo IV foi colocada uma solução de $\mathrm{Ag}\left(\mathrm{NH}_{3}\right)_{2} \mathrm{~F}$ a $38 \%$ no interior do canal antes da aplicação do laser. O laser utilizado foi o de Nd:YAG com 2W, 20 pulsos por

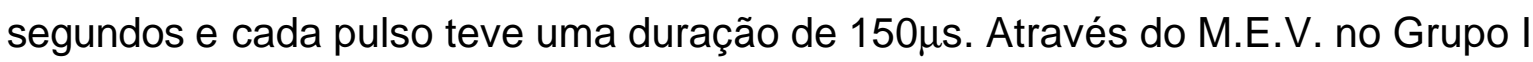
observaram grande quantidade de "smear layer" nas paredes dos canais. No Grupo II a "smear layer" estava presente em muitas partes da parede do canal sem uma aparência derretida. No Grupo III a "smear layer" foi evaporada ou 
fundida, as aberturas dos túbulos dentinários estavam limpas e abertas ou cobertas por dentina derretida. Já o Grupo IV mostrou áreas com uma superfície complexa com áreas de dentina fundida, "smear layer" residual e partículas numerosas e pequenas. Os autores recomendam a aplicação da tinta preta antes da aplicação do laser de Nd:YAG, pois aumenta a sua absorção.

LAN; LIU; LIN ${ }^{60}$, em 1999, avaliaram, através do M.E.V., a ação do laser de Nd:YAG juntamente com o verniz de fluoreto de sódio na oclusão dos túbulos dentinários. Para esse estudo foram utilizados nove dentes molares, dos quais foram preparadas fatias de 3 milímetros de espessura, procedendo-se, em seguida, à remoção da "smear layer" das mesmas com EDTA. As fatias foram divididas em 4 grupos. Nos Grupos A, B e C foi aplicado verniz de fluoreto de sódio e o Grupo D serviu como controle. No Grupo C após aplicação do verniz foi aplicado laser de Nd:YAG em direção perpendicular à superfície dentinária utilizando os seguintes parâmetros: $30 \mathrm{~mJ}$ com 10 p.p.s. por 2 minutos. As fatias dos Grupos B e C, após o tratamento, só verniz (B) ou verniz e laser (C) foram escovadas com uma escova de dentes elétrica, por 30 minutos. As fatias foram preparadas para observação ao M.E.V. No grupo controle os túbulos dentinários apresentaram-se expostos e a "smear layer" foi removida. Com o tratamento da superfície com verniz os túbulos dentinários foram uniformemente ocluídos $(A)$, porém essa oclusão pode ser eliminada após a escovação (B). Nas superfícies onde foi utilizado o verniz e depois o laser (C), a escovação não removeu o verniz, resultando em mais de $90 \%$ dos túbulos dentinários obliterados. A aplicação do laser modificou a superfície dentinária, isso sugere que o verniz combinado com o laser pode ser usado no tratamento da hipersensibilidade dentinária.

No ano de 2000, GOYA et al. ${ }^{44}$ avaliaram as mudanças morfológicas ocorridas na dentina do terço apical de canais que sofreram aplicação de laser de Nd:YAG com e sem aplicação de tinta nanquim no interior do canal. Analisaram também, o selamento da obturação por meio da infiltração de corante. Foram utilizados 60 dentes cujos canais foram instrumentados com limas do tipo $\mathrm{K}$, irrigados com $\mathrm{NaOCl}$ a $5,25 \%$ e peróxido de hidrogênio a $3 \%$ de 
forma alternada e, por último, sofreram uma irrigação com EDTA a $14 \%$. Os dentes foram divididos em 3 grupos: o Grupo I serviu como controle e não foi aplicado laser, o Grupo II sofreu aplicação do laser nos seguintes parâmetros: potência de $2 \mathrm{~W}, 100 \mathrm{~mJ}$ pulso $^{-1}$, freqüência de $20 \mathrm{~Hz}$, a fibra foi introduzido no comprimento de trabalho e o laser foi ativado por 2 segundos, repetindo-se depois de um intervalo de 30 segundos totalizando 4 segundos. No Grupo III, antes da aplicação do laser, foi colocada tinta nanquim nas paredes dos canais em todo o comprimento de trabalho. De cada grupo, 10 dentes tiveram os canais obturados por meio da técnica da condensação lateral. A seguir suas superfícies externas foram impermeabilizadas, com exceção do forame apical, e foram deixadas, por 48 horas, no corante Rodamine B $0,6 \%$. Os outros dez dentes foram preparados para observação ao M.E.V. Em todos os dentes, independente do tratamento, foram encontrados remanescentes de "smear layer", mas com o uso do laser a "smear layer" diminuiu consideravelmente. O Grupo I mostrou uma penetração de corante em $30 \%$ dos espécimes com grande quantidade de "smear layer" obliterando os túbulos dentinários. No Grupo II houve uma diminuição, porém, apenas $20 \%$ dos espécimes tiveram uma penetração de corante menor que 0,5 $\mathrm{mm}$ e apresentou túbulos dentinários abertos com superfície livres de debris e "smear layer". Já no Grupo III não foi observada penetração de corante, mas sim a remoção de debris e "smear layer" mostrando uma superfície limpa, com dentina fundida e recristalizada em muitos casos.

KIMURA; WILDER - SMITH; MATSUMOTO54, em 2000, através de uma revisão de literatura sobre laser indicaram vários procedimentos endodônticos onde o laser pode ser usado: no tratamento da hipersensibilidade dentinária, no capeamento pulpar e pulpotomia, esterilização do canal radicular, limpeza e obturação do canal radicular, apicectomia, fraturas radiculares, esterilização de instrumentos e modificação das características da parede dentinária do canal radicular, pois o laser remove os debris e a "smear layer" e reduz a permeabilidade dentinária pela fusão da dentina, quando usados os parâmetros apropriados. 
TÜRKMEN et al. ${ }^{92}$, em 2000, mediram a alteração da temperatura intrapulpar e avaliaram o efeito do laser na morfologia dentinária, principalmente nos túbulos dentinários. Foram utilizados três tipos de lasers: de $\mathrm{CO}_{2}$, de Nd:YAG e o de ArF. Dividiram os dentes em 3 grupos de 22 dentes cada. Desses dentes 20 tiveram a temperatura medida por um par termoelétrico colocado no interior da câmara pulpar e 2 foram examinados ao M.E.V. O aumento médio da temperatura interna foi de: $37^{\circ} \mathrm{C}$ no de $\mathrm{CO}_{2}, 28^{\circ} \mathrm{C}$ no de $\mathrm{Nd}$ :YAG e $1^{\circ} \mathrm{C}$ no de ArF. Através do M.E.V. puderam observar que houve fusão e recristalização da dentina em algumas áreas e em outras houve exposição dos túbulos tanto com o laser de $\mathrm{CO}_{2}$ como com o de Nd:YAG. Com o laser de ArF a superfície dentinária ficou parecida com favo de mel.

BEZERRA; ARAKI; CALDEIRA ${ }^{11}$, em 2001, analisaram, através de infiltração de corante, a ação dos lasers de Er:YAG e de Nd:YAG ou associação de ambos no selamento apical de obturações de canais radiculares. Para isso utilizaram 36 dentes cujos canais foram instrumentados pelo sistema Profile até o instrumento 40. Esses dentes foram divididos em 4 grupos. Após a instrumentação dos canais, os mesmos foram submetidos à ação do laser, como segue: Grupo 1- irradiado com Er:YAG, Grupo 2- irradiado com Nd:YAG, Grupo 3irradiado com laser de Er:YAG e depois com o de Nd:YAG e o Grupo 4- não foi usado laser. Os canais foram obturados pela técnica da condensação lateral com o cimento AH Plus e imersos em azul de metileno a 0,5\%. Os resultados mostraram não haver diferenças significativas entre os grupos, levando à conclusão de que a aplicação do laser não interferiu no selamento proporcionado pela obturação.

PARK et al. ${ }^{80}$, em 2001, avaliaram o efeito do laser de Nd:YAG na infiltração apical de canais radiculares obturados utilizando-se do método eletroquímico. Foram utilizados 40 dentes unirradiculados que tiveram as coroas removidas e foram divididos aleatoriamente em 4 grupos: Grupo 1- os canais foram instrumentados com limas do tipo $\mathrm{K}$ de número 10 ao 35 pela técnica "step-back", irrigados com $\mathrm{NaOCl}$ a $2 \%$ e irradiados com o laser de $\mathrm{Nd}$ :YAG com $5 \mathrm{~W}$ de potência, freqüência $20 \mathrm{~Hz}$ por um tempo total de 3 
segundos por canal e obturação com a técnica da condensação lateral; Grupo 2igual ao Grupo 1, mas sem aplicação de laser; Grupo 3 instrumentação com Profile com a técnica "crow down" com irradiação com laser igual ao Grupo 1 e obturação com a técnica da condensação vertical; Grupo 4- igual ao Grupo 3, mas sem a aplicação do laser. Após 48 horas, com armazenagem em ambiente com $100 \%$ de umidade, as raízes foram submetidas ao teste eletroquímico. Os resultados mostraram que nos grupos onde foi aplicado laser a infiltração apical foi menor. Segundo os autores essa redução ocorreu, provavelmente, devido a redução da "smear layer" e dos debris, que o laser proporciona.

BASSIL $\beta$, em 2002, avaliou a ação do EDTA e do laser de Nd:YAG no selamento apical utilizando dois tipos diferente de cimento. Para isso utilizou 66 dentes pré-molares inferiores que foram instrumentados nos terços cervical e médio com brocas de Gattes Glidden e no terço apical com sistema Profile e foram irrigados com hipoclorito de sódio a 1\%. Desses dentes, 6 foram preparados para analise ao M.E.V. para observação da ação do laser de Nd:YAG e do EDTA nas paredes dentinárias do canal, sendo três dentes para cada tipo de tratamento. Os 60 dentes restantes foram impermeabilizados e divididos em 4 grupos de 15 dentes em cada: Grupo + aplicação do laser de $\mathrm{Nd}$ :YAG com $1,5 \mathrm{~W}$ de potência, $15 \mathrm{~Hz}$ de freqüência e $100 \mathrm{~mJ}$ de energia e obturação com cimento AH Plus; Grupo II- aplicação do EDTA por 5 minutos e obturação com cimento AH Plus; Grupo III- aplicação do laser de Nd:YAG utilizando os mesmos parâmetros do Grupo I e obturação com cimento Endofill e Grupo IV - aplicação do EDTA por 5 minutos e obturação com cimento Endofill. Os dentes foram imersos em azul de metileno a $2 \%$ por 48 horas, após esse tempo foi feita a leitura da infiltração utilizando um microscópio óptico. $O$ uso do laser proporcionou menores infiltrações do que o EDTA independente do cimento utilizado e o AH Plus apresentou melhor selamento do que o Endofill independentemente do uso ou não do laser. 


\section{2- Uso do EDTA na Endodontia como agente de}

limpeza

O preparo biomecânico é uma das partes mais importantes do tratamento endodôntico, pois é com ele que se consegue a dilatação do canal, grande parte da desinfecção do mesmo, remoção de restos necróticos, neutralização de toxinas, inclusive, propiciando limpeza de grande parte das ramificações. A irrigação juntamente com a instrumentação proporcionam uma limpeza mecânica e química, contudo, essa limpeza não é completa e, independentemente da técnica de instrumentação utilizada, sempre há a formação do que os autores chamam de "smear layer", que é composta por raspas de dentina e de tecidos necróticos ou não, podendo abrigar microrganismos, além de interferir na qualidade do selamento proporcionado pela obturação, por agir como uma interface e dificultar ou impedir o embricamento do cimento obturador nos túbulos dentinários. Por isso a sua eliminação tem sido indicada. Uma das maneiras já consagradas para sua eliminação é a utilização de substâncias quelantes que, além de auxiliar nessa fase, também podem, colaborar na instrumentação de canais atrésicos.

Já em 1894 CALLAHAN $^{16}$ preconizava o uso do ácido sulfúrico a $40 \%$ para dilatação dos canais mais atrésicos.

NIKIFORUK; SCREEBNY ${ }^{75}$, em 1953, usando o EDTA observaram um efeito desmineralizador que era aumentado com a elevação da temperatura da solução.

OSTBY $^{79}$, em 1957, foi um dos primeiros a propor o uso do ácido etileno diamino tetracético em canais radiculares, com a seguinte formulação: $17 \mathrm{~g}$ de EDTA dissódico, $10 \mathrm{ml}$ de água destilada e 9,25 $\mathrm{ml}$ de hidróxido de sódio $5 \mathrm{~N}$. O autor demonstrou o seu efeito amolecedor sobre a dentina radicular, além do que tornava mais fácil a remoção de instrumentos fraturados. Com pesquisas histológicas ele observou a ausência de reações 
biológicas adversas após o uso do EDTA, além de demonstrar que seu uso rotineiro não causa efeitos deletérios aos tecidos pulpares e periapicais.

FEHR; OSTBY ${ }^{32}$, em 1963, avaliaram, através do microscópio, o efeito desmineralizador do ácido sulfúrico e do EDTAC (EDTA com Cetavlon). Para esse experimento foram utilizados 24 dentes que tiveram as coroas removidas e os canais foram instrumentados até que o diâmetro ficasse de 2 a 4 vezes maior que o original. Após seccionamento longitudinal das raízes obteve-se duas hemipartes. Foi aplicada uma camada de parafina em uma das hemipartes do dente, essa parte serviu de controle. As raízes foram divididas em 8 grupos. Em 5 grupos foi aplicado EDTAC, variando-se o período de permanência do produto: 5, 15, e 30 minutos, 24 e 48 horas, e nos outros 3 grupos foi aplicado ácido sulfúrico a $40 \%$, também se alterando o tempo de aplicação: 5 e 15 minutos e 44 horas. Após esses períodos foram realizados cortes transversais de mais ou menos 150 a $200 \mu \mathrm{m}$ e foram analisados no microscópio com um aumento de 25 vezes. Concluíram que o EDTAC tem um efeito desmineralisador mais rápido e é limitado; aos 5 minutos quelou uma camada de dentina de 20 a $30 \mu \mathrm{m}$ e com 48 horas já se notava uma remoção completa de sais minerais da parede dentinária na profundidade de $50 \mu \mathrm{m}$. $\mathrm{O}$ ácido sulfúrico apresentou um efeito desmineralisador lento e incompleto, não removeu cálcio e sim converteu a hidroxiapatita em sulfato de cálcio.

FRASER $^{35}$ avaliou, em 1974, a ação das seguintes soluções: Decal, Largal Ultra e RC-prep. Para isso foram utilizados 30 dentes anteriores humanos que, foram divididos em três grupos e, em seguida, seccionados longitudinalmente no sentido mésio-distal; tiveram a polpa removida e as metades lavadas em água corrente. Nesses grupos uma das metades correspondia ao controle, as quais receberam irrigação com água, e as suas correspondentes foram irrigadas com as substâncias em teste, durante 15 minutos. Após esse tempo as metades foram lavadas e unidas com a sua correspondente com resina acrílica, aplicada externamente. Foram feitos cortes transversais nos terços cervical, médio e apical. Concluíram que o Largal Ultra foi 
mais eficiente, seguido pelo Decal e por último o RC-prep. No terço apical a desmineralisação da dentina não passou de $20 \mu \mathrm{m}$.

GOLDBERG; ABRAMOVICH ${ }^{41}$, em 1977, analisaram a ação do EDTAC na superfície radicular dentinária. Utilizaram 6 dentes que tiveram os canais instrumentados e irrigados com solução salina durante a instrumentação. Esses dentes foram partidos ao meio obtendo-se 12 hemi-partes. Dessas, 6 foram usadas como controle e não receberam nenhum tratamento e nas outras 6 foi aplicado EDTAC por 15 minutos, sendo secas e novamente aplicado EDTAC por mais 15 minutos. Os espécimes foram preparados para observação ao M.E.V. O grupo controle apresentou uma superfície coberta por material amorfo e os túbulos dentinários estavam parcial ou completamente encobertos. No grupo experimental os túbulos dentinários estavam aparentes e com os diâmetros maiores. Os autores concluíram que o uso do EDTAC resulta na eliminação da camada residual superficial ("smear layer") aumentando o diâmetro dos túbulos dentinários, contribuindo com a limpeza e antissepsia, facilita a ação de curativos, além de facilitar a adesão do material obturador.

BAUMGARTNER; MADER ${ }^{9}$ avaliaram, em 1987, a capacidade de limpeza da solução salina, do $\mathrm{NaOCl}$ a 5,25\% e solução de EDTA a 15\%. Utilizando dentes com 2 canais, apenas um foi instrumentado, e ambos receberam irrigação com essas substâncias. Cada canal foi irrigado com um total de $33 \mathrm{ml}$ da solução irrigante, sendo usadas no momento da extirpação pulpar e a cada troca de instrumento quando se instrumentou. Todos os canais receberam uma irrigação final com água destilada, foram secos e preparados para observação ao M.E.V. O EDTA foi a substância que mais desmineralizou dentina expondo os túbulos, nos canais instrumentados. Entretanto, nos canais que não sofreram instrumentação ele foi ineficaz na remoção de tecido pulpar remanescente. A solução salina também apresentou comportamento ruim quando comparada aos outros irrigantes. $\mathrm{O} \mathrm{NaOCl}$ nos canais não instrumentados mostrou eficiência, removendo grande parte dos remanescentes pulpares, contudo, nos canais instrumentados sua eficiência foi inferior a do EDTA. A combinação de $\mathrm{NaOCl}$ e EDTA foi o procedimento que apresentou melhores 
resultados, removendo a "smear layer" dos canais instrumentados e também os restos pulpares dos canais não instrumentados, causando exposição de calcosferitas dando uma aparência de superfície corroída.

ZUOLO et al. ${ }^{105}$, em 1987, avaliaram a ação do EDTA e suas associações sobre a permeabilidade da dentina. Foram utilizados 25 incisivos centrais superiores cujos canais foram instrumentados, tiveram a coroa removida, foram impermeabilizados externamente com parafina e divididos em 5 grupos, de acordo com as seguintes soluções: Grupo I - EDTA 15\%, Grupo II EDTA com Cetavlon (EDTAC), Grupo III - EDTA com Tergentol (EDTAT), Grupo IV - EDTA com Cloreto Cetil Piridino (EDTACP) e Grupo V - Soro fisiológico. Os canais foram secos e receberam os reagentes químicos do ensaio histoquímico para determinar a permeabilidade dentinária. As regiões cervical e média tiveram maiores níveis de penetração, independente da solução utilizada. $O$ detergente catiônico Cetavlon contribuiu para uma melhor efetividade do EDTA promovendo uma maior permeabilidade, já a solução de EDTA ficou em uma posição intermediária.

CIUCHI; KHETTABI; HOLZ22, em 1989, compararam a efetividade de quatro maneiras diferentes utilizadas para remoção de "smear layer". Foram utilizados 40 dentes cujos canais foram instrumentados manualmente com limas flexo-file e irrigados com $\mathrm{NaOCl}$ a $3 \%$. Os dentes foram divididos em 4 grupos: Grupo I - não foi realizado nenhum tratamento adicional, Grupo II - foi realizada irrigação com $\mathrm{NaOCl}$ e utilização de ultra-som, Grupo III irrigação com EDTA por 3 minutos e Grupo IV - irrigação com EDTA e utilização de ultra-som. Os dentes foram preparados para observação ao microscópio eletrônico de varredura e notourse que a "smear layer" foi removida com maior efetividade após o uso do EDTA por 3 minutos (Grupo III).

No ano de 1990, CENGIZ et al. ${ }^{21}$ avaliaram a capacidade de remoção da "smear layer" em túbulos dentinários de diferentes direções, oferecida por 3 diferentes métodos. Para isso foram utilizados cinco molares, dos quais foram removidas as raízes, e nos remanescentes coronários confeccionour se 3 orifícios, dando origem a três canais artificiais em cada dente, totalizando 15 
canais. Esses foram instrumentados até a lima do tipo $\mathrm{K}$ número 70 com comprimentos de 7 a $9 \mathrm{~mm}$. Outros 15 dentes unirradiculados, com 1 canal, também tiveram os canais instrumentados. Os espécimes foram divididos em 3 grupos, cada um incluindo cinco canais artificiais e 5 canais naturais: Grupo I irrigação com solução salina, Grupo II - irrigação com EDTA 15\%, Grupo III irrigação com EDTA $15 \%$ e com $\mathrm{NaOCl} 5,25 \%$. Os canais foram secos e preparados para análise ao M.E.V. No Grupo I não houve remoção da "smear layer", no Grupo II a "smear layer" foi removida, mas alguns túbulos permaneceram fechados e no Grupo III toda a "smear layer" foi removida. Não houve diferença em relação à direção dos túbulos dentinários. Já a combinação de EDTA e $\mathrm{NaOCl}$ foi mais eficiente.

Também no ano de 1990, GUTIERREZ et al. ${ }^{47}$ avaliaram a ação de limpeza do EDTA, do $\mathrm{NaOCl}$ a 5,25\% e do peróxido de hidrogênio a $3 \%$, em diferentes momentos do tratamento endodôntico. Para isso foram utilizados 27 dentes que foram divididos em 3 grupos: Grupo I - irrigação durante a instrumentação com $\mathrm{NaOCl}$ a 5,25\% alternando com peróxido de hidrogênio a $3 \%$, Grupo II - irrigação durante a instrumentação com NaOCl a 5,25\% alternando com peróxido de hidrogênio a 3\% e irrigação final com EDTA a 17\% e solução de $\mathrm{NaOCl}$ a 5,25\% e Grupo III - irrigação com água destilada durante a instrumentação e irrigação final com EDTA a 17\%. Os resultados mostraram que o Grupo III foi o que melhor se comportou em relação à remoção da "smear layer", seguido pelo Grupo II e, por último, o Grupo I.

AKTENER; BILKAY² observaram, em 1993, a ação do EDTA e do etilenodiamine (ED- solvente orgânico), na remoção da "smear layer". Para isso foram utilizados 35 dentes unirradiculados, que tiveram os canais instrumentados até a lima do tipo $\mathrm{K}$ número 50 e irrigados com soro fisiológico. Os dentes foram fraturados longitudinalmente e divididos em 7 grupos: Grupo Iirrigação com $10 \mathrm{ml}$ de soro fisiológico, Grupo II- $10 \mathrm{ml}$ com quatro partes de EDTA e 1 parte de ED, Grupo III- $20 \mathrm{ml}$ com quatro partes de EDTA e 1 parte de ED, Grupo IV - $10 \mathrm{ml}$ com quatro partes de EDTA e 2 partes de ED, Grupo V- 20 $\mathrm{ml}$ com quatro partes de EDTA e 2 partes de ED, Grupo Vt $10 \mathrm{ml}$ com quatro 
partes de EDTA e 3 partes de ED e Grupo VII- $20 \mathrm{ml}$ com quatro partes de EDTA e 1 parte de ED. Essas substâncias foram deixadas por 1 minuto nos Grupos I, II, IV e VI e 2 minutos nos Grupos III, V e VII. A irrigação final foi realizada com soro fisiológico e os dentes foram preparados para observação ao M.E.V. O Grupo I apresentou uma grande quantidade de "smear layer" em todos os níveis de todos os espécimes, nos Grupos II e IV foi removida a "smear layer" mais superficial, no terço médio de dois espécimes e no apical de todos, apenas alguns túbulos estavam abertos. Nos Grupos III e V a "smear layer" foi removida quase que totalmente. Nos Grupos VI e VII a "smear layer" superficial foi removida em todos os espécimes e os túbulos dentinários ficaram totalmente abertos.

CALERÓ et al. $^{15}$, em 1997, utilizando-se da espectrofotometria de absorção atômica, avaliaram a velocidade e intensidade da reação do EDTA com os íons cálcio da dentina e seu grau de saturação em relação ao tempo de aplicação. Para isso foram utilizados 256 dentes unirradiculados, com um canal cada, que foram instrumentados e irrigados com água destilada e, em seguida, divididos em 8 grupos. Neles foi aplicado EDTA alterando-se o tempo de permanência do produto em contato com as paredes dos canais, que foi de $1,3,5,10,15,20,30$ e 120 minutos. Através da absorção atômica determinourse a quantidade de cálcio presente. Com os resultados observou-se que a descalcificação está diretamente relacionada ao tempo de permanência do EDTA dentro do canal, mas essa descalcificação vai diminuindo devido ao grau de saturação do EDTA, limitando a possibilidade de captação de íons cálcio. A ação do EDTA só se inicia após 1 minuto depois da aplicação. Recomendaram uma irrigação final com soro, uma vez que a ação do EDTA pode continuar por maior tempo.

DIEP; BRAMANTE ${ }^{28}$, em 1997, avaliaram a limpeza proporcionada pelo EDTA quando utilizado de maneiras diferentes, avaliando a ação por terços e nas paredes proximal e lingual. Foram utilizados 60 pré-molares inferiores, cujos canais foram instrumentados e, então, divididos em 10 grupos: Grupo I - irrigação com água destilada durante a instrumentação e irrigação final com EDTA por 1 minuto, análise na parede proximal; Grupo II - irrigação com 
água destilada durante a instrumentação e irrigação final com EDTA por 1 minuto, análise na parede lingual; Grupo III - irrigação com água destilada e EDTA a cada troca de instrumento, análise na parede proximal; Grupo IV - irrigação com água destilada e EDTA a cada troca de instrumento, análise na parede lingual; Grupo V - irrigação com $\mathrm{NaOCl}$ a 1\% e EDTA a cada troca de instrumento, análise na parede proximal; Grupo VI - irrigação com NaOCl 1\% e EDTA a cada troca de instrumento, análise na parede lingual; Grupo VII - irrigação com EDTAC durante toda a instrumentação e irrigação fnal com água destilada, análise na parede proximal; Grupo VIII - irrigação com EDTAC durante toda a instrumentação e irrigação final com água destilada e análise na parede lingual; Grupo IX - irrigação com água destilada durante toda instrumentação, análise na parede proximal e Grupo X - irrigação com água destilada durante toda instrumentação, análise na parede lingual. Os dentes foram seccionados e preparados para observação ao M.E.V. O resultado apresentou a seguinte seqüência, do mais eficiente para o menos: EDTAC durante a instrumentação, EDTA por 1 minuto final, EDTA alternado com água destilada, EDTA alternado com $\mathrm{NaOCl} 1 \%$ e, por último, a água destilada. Não houve diferenças estatísticas entre os grupos nos quais se usou o EDTA. Com relação aos terços o apical foi o que se apresentou menos limpo e não houve diferença significativa entre os terços cervical e médio. Em relação às paredes, a proximal ficou mais limpa que a lingual.

Em 1999, TAKEDA et al. ${ }^{90}$ analisaram a ação de limpeza do EDTA a 17\%, do ácido cítrico a 6\%, do laser de $\mathrm{CO}_{2}$ e do laser de Er:YAG. Para esse estudo foram utilizados 60 pré-molares unirradiculados que tiveram os canais instrumentados e irrigados com $\mathrm{NaOCl}$ a 5,25\% e peróxido de hidrogênio a $3 \%$ a cada troca de instrumento e irrigação final com água destilada. Após a instrumentação os dentes foram divididos em 5 grupos: Grupo I- aplicação de $10 \mathrm{ml}$ de EDTA a $17 \%$ por 5 minutos, depois $3 \mathrm{ml}$ de $\mathrm{NaOCl}$ a $5,25 \%$ e por último $3 \mathrm{ml}$ de água destilada, Grupo II- $10 \mathrm{ml}$ de ácido fosfórico a 6\% por 5 minutos, depois $3 \mathrm{ml}$ de $\mathrm{NaOCl}$ e por último $3 \mathrm{ml}$ de água destilada, Grupo III- de $10 \mathrm{ml}$ de ácido cítrico a $6 \%$ por 5 minutos, depois $3 \mathrm{ml}$ de $\mathrm{NaOCl}$, Grupo IV-irradiação com laser de $\mathrm{CO}_{2}$ com $1 \mathrm{~W}$, modo contínuo, com um total de 23 segundos e Grupo V- 
irradiação com laser de Er:YAG com 1W, $100 \mathrm{~mJ}$ e $10 \mathrm{~Hz}$. Os canais foram secos e os dentes seccionados longitudinalmente e preparados para análise ao M.E.V. No Grupo I houve remoção da "smear layer" no terço médio, alguns espécimes apresentaram "smear plugs", o terço apical encontrava-se menos limpo. Nos Grupos II e III as paredes mostraram-se limpas, mas no terço apical, em algumas áreas notava-se presença de "smear layer". No Grupo IV não se notava presença de "smear layer", sendo que no terço apical observourse áreas de fusão e recristalização de dentina e o Grupo V foi o que apresentou melhor limpeza. Pelos resultados concluíram que os lasers foram que melhor limparam a superfície dentinária, principalmente o de Er:YAG.

ÇALT; SERPER ${ }^{18}$, em 2000, avaliaram o efeito do EGTA (ácido tetracético etilenoglicol) na remoção da "smear layer" como alternativa ao EDTA. Foram utilizados 15 dentes com um canal que foram instrumentados e irrigados com $\mathrm{NaOCl}$ a 5\%. Três dentes serviram como controle e receberam uma irrigação final com $10 \mathrm{ml}$ de $\mathrm{NaOCl}$ a $5 \%$. Os restantes foram divididos em dois grupos: Grupo I - irrigação final com $10 \mathrm{ml}$ de EDTA a 17\% por 2 minutos e Grupo II - irrigação final com 10ml de EGTA a 17\% por 2 minutos. As raízes foram seccionadas longitudinalmente e preparadas para observação ao M.E.V. Os espécimes do grupo controle mostraram um acúmulo de "smear layer" nas paredes, o grupo com EDTA teve toda a "smear layer" removida em todos os terços e apresentou erosões na dentina principalmente no terço médio. No grupo onde se usou EGTA a remoção da "smear layer" foi parcial pois não ocorreu no terço apical. O EGTA não foi tão efetivo como o EDTA no terço apical, porém mostrou-se ser menos deletério, já que o EDTA causou erosões dentinárias.

AMORIM; LAGE-MARQUES ${ }^{3}$, em 2001, avaliaram a infiltração da Rodamina B na massa dentinária após a instrumentação e irrigação dos canais radiculares de 27 dentes. Esses dentes foram divididos em 3 grupos experimentais: Grupo I - $\mathrm{NaOCl}$ 0,5\% mais creme Endo PTC e irrigação final com EDTA -T; Grupo II - NaOCl 0,5\% mais Glyde File Prep; Grupo III - NaOCl a 0,5\% mais File Eze e um grupo controle, onde se utilizou a água destilada. Os canais foram secos com cones de papel absorvente e a solução corante foi injetada 
preenchendo o canal e na seqüência foi removida imediatamente por aspiração e secagem com cones de papel. Cada espécime foi cortado transversalmente em 5 partes, as amostras foram digitalizadas, e com auxílio do computador, foi calculada a média de infiltração na massa dentinária. Os autores concluíram que a permeabilidade dentinária aumentou de maneira semelhante para todas as substâncias utilizadas. Em relação aos terços, o apical se mostrou menos permeável.

CARDOSO; TORRES; PROKOPOWITSCH ${ }^{20}$ em 2001, avaliaram a ação do EDTA-T, do líquido de Dakin e da clorexidina a $2 \%$ na remoção do curativo de hidróxido de cálcio do interior dos canais radiculares. Para isso foram utilizadas 30 raízes de dentes bovinos cujos canais foram instrumentados e preenchidos com pasta de hidróxido de cálcio e permaneceram em ambiente seco por um período de 15 dias. As raízes foram divididas em 3 grupos conforme a substância irrigante utilizada para remover o curativo juntamente com uma lima do tipo $\mathrm{K}$ número 25 . As raízes foram impermeabilizadas e imersas em solução de azul de metileno a 0,5\% por 12 horas. Após esse tempo foram lavadas e cortadas para observação no microscópio óptico e, com o auxílio de um computador, foram avaliadas as áreas coradas. O grupo onde se utilizou o EDTA-T apresentou os melhores resultados, removendo toda a medicação.

OLIVEIRA et al. ${ }^{77}$ avaliaram, em 2001, a ação do EDTA a $17 \%, \mathrm{NaOCl}$ a 5,25\%, Endoquill, e o Gel de Natrosol, na remoção da "smear layer" e, conseqüentemente, na limpeza da parede dentinária. Foram utilizados 25 dentes humanos unirradiculados, que foram divididos em 5 grupos: Grupo 1 irrigação com EDTA 17\%, Grupo 2 - irrigação com NaOCl a 5,25\%, Grupo 3 irrigação com Endoquill, Grupo 4 - uso do Gel de Natrosol e Grupo 5 - irrigação com água destilada. Os dentes foram seccionados e preparados para observação ao M.E.V. Os resultados mostraram não haver diferença estatística entre os Grupos 1, 3 e 4, os quais apresentaram melhor limpeza, seguido pelo $\mathrm{NaOCl}$ e, por último, a água destilada. 
RIBEIRO; MEDINA; MORAES ${ }^{84}$ em 2001, avaliaram a infiltração marginal apical em canais obturados após a utilização de diferentes agentes irrigantes: EDTA, ácido cítrico a 10\%, clorexidina $2 \%$ e Endoquill. Foram utilizados 40 incisivos centrais superiores extraídos que tiveram as suas coroas removidas, os forames apicais foram padronizados com uma lima do tipo $\mathrm{K}$ número 30, o instrumento de memória preconizado foi uma lima número 45 , fazendo-se o escalonamento regressivo até a de número 70. Os dentes foram obturados com guta-percha e cimento Endomethasone pela técnica da condensação lateral passiva e imersos imediatamente em azul de metileno $2 \%$ por 72 horas a $37^{\circ} \mathrm{C}$. As raízes foram desgastadas longitudinalmente e, após a exposição das obturações, foram analisadas as infiltrações em microscópio pela técnica da planimetria. Os resultados mostraram a seguinte ordem decrescente de infiltração: Endoquill, ácido cítrico 10\%, clorexidina 2\% e EDTA, este mostrou um comportamento melhor.

No ano de 2002, ÇALT; SERPER ${ }^{19}$ avaliaram a ação do EDTA na remoção da "smear layer" nos tempos de 1 e 10 minutos. Os canais foram instrumentados com lima do tipo $\mathrm{K}$ e com brocas de Gates Glidden e irrigados com hipoclorito de sódio a 5\%. Utilizoutse apenas o terço médio dos canais, sendo eliminados, com brocas, os terços apical e cervical. Assim, o terço radicular médio foi cortado ao meio no sentido longitudinal obtendo-se duas hemipartes. Em uma foi aplicado EDTA deixando-o agir por 1 minuto e na outra, também foi aplicado EDTA, porém deixando-o atuar por 10 minutos. Após @s tempos determinados foi feita uma irrigação com $\mathrm{NaOCl}$ a $5 \%$ e os espécimes foram preparados para avaliação ao microscópio eletrônico de varredura. Os resultados mostraram que com o tempo de 1 minuto já houve a remoção completa da "smear layer" e abertura dos túbulos dentinários. Com o tempo de 10 minutos, notou-se a remoção da "smear layer" e uma excessiva erosão na dentina intertubular e peritubular e os túbulos dentinários tiveram seus diâmetros aumentados.

VILLEGAS et al. $^{93}$, em 2002, avaliaram a obturação de canais acessórios usando o System B mais o Obtura II após a utilização de quatro 
tipos diferentes de irrigantes. Foram utilizados 64 dentes pré-molares que possuíam canais acessórios comprovados radiograficamente. Eles foram instrumentados em seus terços cervical e médio utilizando-se brocas de Gattes Glidden e limas Profile no terço apical. Foi utilizado RC prep durante a instrumentação e a cada troca de instrumento foi irrigado com $\mathrm{NaOCl}$ a $6 \%$. Os dentes foram divididos em 4 grupos: Grupo I - sem irrigação final, Grupo II irrigação com água destilada, Grupo III - NaOCl a 6\% e Grupo IV - EDTA por 3 minutos. Os canais foram secos e obturados. Foram realizadas radiografias mésio-distal e depois os dentes diafanizados para observação no microscópio. A média de penetração de material obturador nos canais acessórios foi calculada, dividindo o comprimento da penetração do material pelo comprimento do canal acessório. Os resultados foram: sem irrigação $22,3 \%$, água 21,8\%, $\mathrm{NaOCl} 53,5 \%$ e EDTA $68,1 \%$. Em alguns canais foram encontrados espaços vazios entre 0 cimento e a guta-percha, que podem ter sido ocasionados pela presença de bolhas de ar.

\section{3- A presença e a importância dos canais laterais}

O canal lateral faz parte do sistema de canais que existe nos dentes, descrito por PUCCl; REIG ${ }^{82}$ em 1944 e complementado por $\mathrm{KUTLER}^{57}$ em 1961. A sua presença nem sempre é percebida, mas a sua importância é fundamental, uma vez que nele também podem ficar abrigados restos pulpares inflamados e/ou infectados, restos necróticos e bactérias. Todas as etapas do preparo do canal radicular são muito importantes sempre objetivando que no final todo o sistema de canais possa ser obturado, inclusive os canais laterais.

DE DEUS ${ }^{26}$, em 1975, analisou 1140 dentes humanos, tanto inferiores como superiores e investigou a freqüência, localização e direção de canais laterais, secundários e acessórios. Os dentes que apresentaram maior número de ramificações foram os pré-molares e molares. Do total, 313 (27,4\%) mostraram canais laterais, secundários e acessórios. A área de maior ocorrência 
foi o terço apical, seguido pelo terço médio e, por fim, o coronário. Canais laterais foram encontrados em 10,4\% dos dentes estudados. Para o autor, esses canais são importantes, pois fazem a ligação entre o periodonto e a polpa e estão muito relacionados aos problemas endo-periodontais.

$\mathrm{XU}$; ZHANG ${ }^{102}$, em 1984, relataram dois casos de problemas endodônticos onde, ao exame radiográfico, as lesões inflamatórias apareciam localizadas lateralmente à raiz. Clinicamente observava-se presença de fístula. Com a obturação do canal principal, certificou-se radiograficamente da obturação de um canal lateral e, com o passar do tempo, notourse o desaparecimento da lesão. Com o relato desses fatos fica claro a importância da obturação correta de todo sistema de canais radiculares, pois canais laterais abrigam tecidos necróticos e bactérias remanescentes, podendo ser fonte de infecção.

WEINE ${ }^{95}$, em 1984, publicou um artigo que respondia a vários questionamentos sobre canais laterais. Começou por diferenciar canais laterais de acessórios, os primeiros se estendem do centro do canal principal até ao ligamento periodontal, freqüentemente é perpendicular ao principal e são encontrados nos terços médio e cervical, já os canais acessórios são menores e são encontrados na região apical. Uma limpeza eficiente nos canais principais ajuda, conseqüentemente, na limpeza dos canais laterais. Comentou que o uso do $\mathrm{NaOCl}$ é importante, pois dissolve os remanescentes de restos necróticos que podem se encontrar dentro dos canais laterais. Lesões laterais são freqüentes e estão relacionadas com a presença desses canais. Para o autor as técnicas termoplastificadoras para obturação são as que melhor obturam os canais laterais, todavia, nem sempre a obturação de um canal lateral é sinônimo de que o canal principal esteja bem obturado. $O$ dente que mais apresenta canais laterais é o pré-molar inferior. A furca de molares é uma região onde se pode encontrar canais acessórios e laterais, isso é de extrema importância, pois há uma ligação direta com o ligamento periodontal, onde vias de contaminação podem ocorrer, tanto da polpa para o periodonto como deste para a polpa. Entretanto, isto pode ocorrer em outros tipos de dente, principalmente se este apresentar um canal 
lateral próximo à gengiva marginal. O número de canais laterais existentes é muito maior do que aquele que é obturado durante os tratamentos endodônticos, e essa diferença é causa de muitos insucessos do tratamento.

BRITTO et al. ${ }^{13}$, em 1986, relacionaram a presença de canais laterais e acessórios à lesão endo-periodontal. Segundo esses autores, quando canais acessórios estão localizados, principalmente, no terço cervical da raiz ou área de furca e esse dente é possuidor de uma bolsa periodontal profunda, isto pode levar a uma inflamação pulpar ou, também, uma polpa doente pode desencadear uma doença periodontal. Eles exemplificaram essa afirmação citando quatro casos onde os dentes sofreram tratamentos endodônticos e periodontais, e sempre havia canais laterais e acessórios envolvidos. Após os tratamentos todos os casos obtiveram sucesso.

WOLCOTT et al. ${ }^{100}$, em 1997, compararam a habilidade das técnicas da condensação lateral e do Thermafill em obturar canais principais e canais laterais em angulações diferentes. Foram utilizados 30 blocos de resina epóxica, nos quais foram simulados canais principais de diâmetro correspondente ao de uma lima do tipo $\mathrm{K}$ número 50 e canais laterais em cinco angulações diferentes, com diâmetros semelhantes ao da lima do tipo $\mathrm{K}$ número 10 . Os blocos foram divididos em 2 grupos: Grupo 1 - obturado com a técnica da condensação lateral utilizando cones de guta-percha e cimento, e o Grupo 2 obturado com a técnica Thermafill com cimento. Os blocos permaneceram por sete dias em umidade de 100\%. Após esse tempo foi medida, utilizando-se de um microscópio, a quantidade de guta-percha e/ou cimento que penetrou nos canais laterais, bem como dos espaços vazios existentes. Os resultados mostraram haver diferenças estatisticamente significante entre os grupos. Havia mais gutapercha nos canais laterais no grupo onde foi obturado com Thermafill (Grupo 2). A condensação lateral proporcionou uma obturação somente com cimento, penetrando em todos os canais laterais com exceção de um que se localizava mais apicalmente, formando um ângulo de quase $180^{\circ} \mathrm{com}$ a região mais apical do canal principal. Concluiu-se que uma técnica termoplastificadora produz um melhor selamento dos canais laterais 
GOLDBERG; ARTAZA; DE SILVIO ${ }^{42}$, em 2001, compararam a eficiência de seis técnicas de obturação, no selamento de canais laterais confeccionados artificialmente. Utilizaram 60 dentes, nos quais foram confeccionados canais laterais na superfície mesial e distal das raízes com 0 auxílio de um alargador rotatório de número 15. Os dentes foram divididos aleatoriamente em 6 grupos de acordo com as técnicas obturadoras: Grupo I Condensação lateral, Grupo II - Híbrida de Tagger, Grupo III - Ultrafil, Grupo IV Obtura II, Grupo V - System B/Obtura II e Grupo VI - Thermafil. As análises foram realizadas através de radiografias, concluindo-se que a técnica do Ultrafil foi aquela que apresentou maior número de canais laterais obturados, seguida pelo: Thermafil, System B/Obtura II, Híbrida de Tagger, Obtura II e por último a condensação lateral. Os autores observaram também que os terços médio e cervical tiveram maior número de canais laterais artificiais obturados.

ORTEGA et al. $^{78}$, em 2001, utilizaram 40 incisivos inferiores, nos quais confeccionaram canais laterais artificiais nos terços médio e apical, instrumentando, a seguir, o canal principal com o objetivo de avaliar o desempenho dos cimentos Fill Canal, Sealer 26, Sealapex e AH Plus, na capacidade de obturar canais laterais. A técnica obturadora utilizada foi a técnica Híbrida de Tagger. As análises foram feitas por meio de radiografias. $\mathrm{O}$ cimento com melhor desempenho foi o AH Plus, seguido pelo Fill Canal, Sealer 26 e por último Sealapex. Os autores também observaram que os canais laterais pertencentes ao terço médio foram obturados em maior número do que os pertencentes ao terço apical.

GOLDBEG; ARTAZA; DE SILVIO ${ }^{43}$, em 2002, avaliaram a influência do curativo de hidróxido de cálcio na obturação de canais laterais confeccionados artificialmente. Para isso foram utilizados 20 dentes portadores de um canal principal e que, após a confecção dos canais laterais foram instrumentados com brocas de Gates Glidden nos terços cervical e médio e com limas do tipo $\mathrm{K}$ no terço cervical, tendo como instrumento de memória a lima número 35. Durante toda a instrumentação os canais foram irrigados com $\mathrm{NaOCl}$ a 2,5\%. Os dentes foram divididos em 2 grupos: Grupo A - obturação com o 
sistema Ultrafill, utilizando o cimento AH 26 e Grupo B - colocação de curativo com pasta de hidróxido de cálcio, preparada com água destilada, por uma semana e depois remoção dessa pasta e obturação de maneira idêntica à do Grupo A. Os dentes foram radiografados no sentido vestíbulo - lingual, mostrando um número maior de canais laterais obturados no grupo onde não se usou o curativo. 
3- Proposição 


\section{3-PROPOSIÇÃO}

Esse trabalho teve como objetivos:

- Comparar a ocorrência de obturação de canais laterais artificiais em diferentes terços, entre os dentes que, após a instrumentação, tiveram as paredes dos canais radiculares, tratadas com EDTA, com laser de Nd:YAG ou com EDTA associado ao laser de Nd:YAG;

- Analisar, em microscopia eletrônica de varredura, as características da dentina parietal nos diferentes terços, principalmente quanto aos túbulos dentinários, e das embocaduras dos canais laterais dos dentes cujos canais tiveram as paredes tratadas das maneiras acima mencionadas. 
4- Material e Métodos 


\section{4- Material e métodos}

Foram utilizados 54 dentes pré-molares inferiores humanos, extraídos, conservados em solução de formol a 10\%, portadores de um único canal, provenientes do arquivo de dentes da disciplina de Endodontia da Faculdade de Odontologia de Bauru, obtidos antes de 1997.

Inicialmente foram removidas as coroas dos dentes, padronizando-se o tamanho das raízes entre 14 a $17 \mathrm{~mm}$ (comprimento real da raiz).

\section{Preparo dos canais laterais}

Para facilitar a identificação e descrição, aqueles canais, mesmo os localizados no terço apical, foram chamados de canais laterais.

Limas do tipo $K^{*}$ № 10 tiveram 2,5 mm da suas pontas ativas cortadas de modo chanfrado. Os cabos e os intermediários também foram removidos, restando apenas as partes ativas ou lâminas já preparadas.

$\mathrm{Na}$ parte mais calibrosa da lâmina, utilizando-se da técnica do pincel aplicou-se resina acrílica ativada quimicamente em toda a volta da lâmina, aumentando o seu diâmetro, deixando mais ou menos 5 milímetros da ponta da lima, livre, sem aplicação de resina.

A resina foi modelada de forma cilíndrica e, então, desgastada com broca Max-Cuti até que se encaixasse no adaptador de brocas de alta rotação (usado quando se deseja usar brocas de alta rotação no aparelho de baixa rotação).(Figura 1)

"Maillefer - Ballaigues, Suíça 


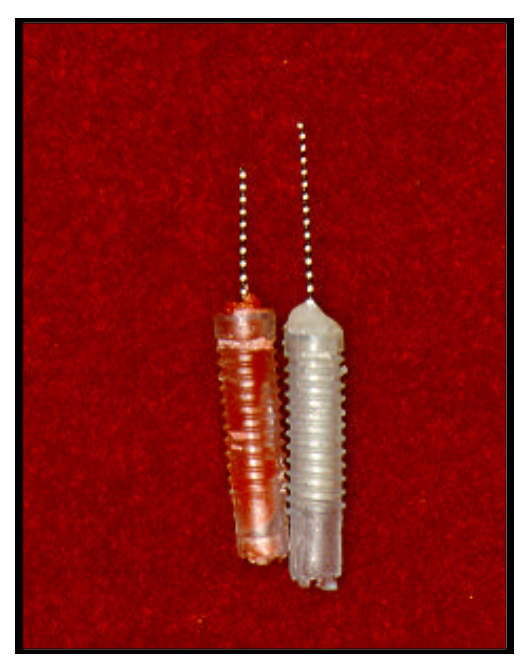

Figura 1 - Alargadores preparados

Assim, essa lima, inicialmente fabricada para utilização manual, foi transformada em um instrumento para ser usado no contra-ângulo, como instrumento rotatório.(Figura 2)

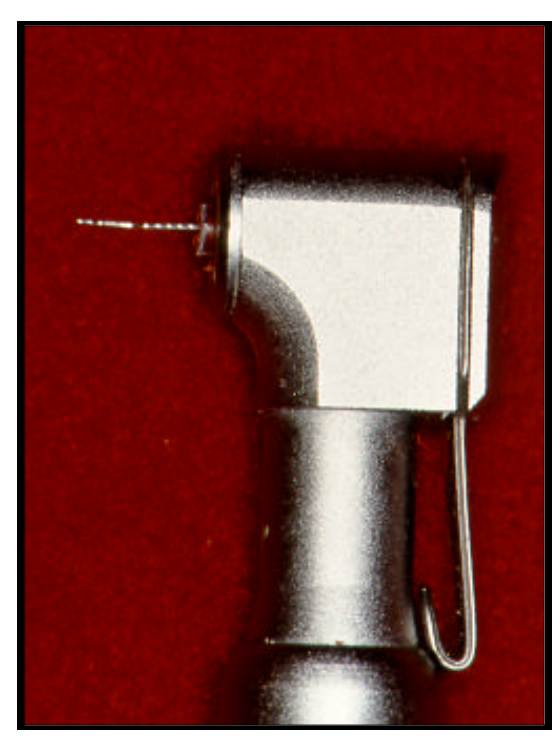

Figura 2 - "Alargador" acoplado ao contra - ângulo

Com esse instrumento foram realizadas três perfurações radiculares em uma das faces proximais de cada raiz, perpendicular ao eixo do 
canal, obtendo-se os canais laterais artificiais, estrategicamente localizados nos terços apical, médio e cervical.(Figura 3 e 4)

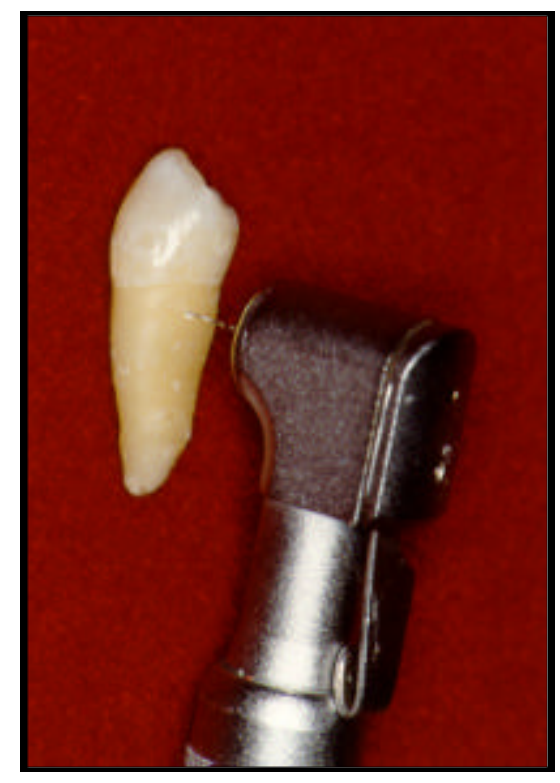

Figura 3 - Confecção do canal

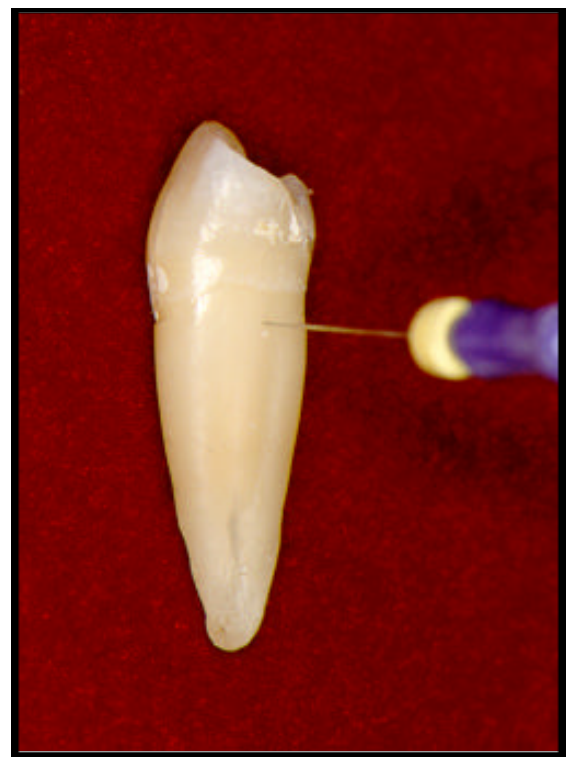

Figura 4 - Lima do tipo K no 10 posicionada no canal lateral já confeccionado 
Odontometria

A odontometria foi feita visualmente. Uma lima do tipo $\mathrm{K}$ no 10, munida de um limitador de penetração, era introduzida no canal radicular até que sua extremidade fosse visualizada na altura do forame apical. Após posicionada a extremidade da lima rente ao forame apical, o limitador foi assentado na parede dentinária adjacente à embocadura do canal radicular e, então, o instrumento foi removido. Mediu-se a distância entre a ponta da lima e o limitador de penetração, obtendo-se o comprimento real da raiz. Dessa medida foi subtraído 1 milímetro para a dilatação do canal e sua futura obturação.

\section{Irrigação}

Para a irrigação empregourse uma seringa Luer Look de 5 cc de capacidade e cânula 30/4.

O líquido irrigador utilizado foi uma solução de hipoclorito de sódio a $1 \%{ }^{*}$ (líquido de Milton), durante toda a instrumentação, utilizando-se 1 $\mathrm{ml}$ do líquido a cada troca de instrumento. Ao final da instrumentação os canais foram irrigados com $5 \mathrm{ml}$ de soro fisiológico.

\section{$\underline{\text { Instrumentação }}$}

Os canais foram instrumentados utilizando-se, inicialmente, brocas de Gates-Glidden ${ }^{* *}$ de números de 2 ao 5 nos terços médio e cervical. As extensões utilizadas foram calculadas da segui nte maneira: 
Comprimento de trabalho do dente $-5 \mathrm{~mm}=\mathrm{x} \mathrm{mm}$

Gattes ํㅡ 2: extensão de $x$ mm

Gattes no 3: extensão de $x \mathrm{~mm}-2 \mathrm{~mm}$

Gattes ํㅡ 4: extensão de $x \mathrm{~mm}-4 \mathrm{~mm}$

Gattes $\mathrm{n}^{0}$ 5: extensão de $\mathrm{x} \mathrm{mm}-6 \mathrm{~mm}$

A instrumentação do terço apical foi realizada com limas manuais do tipo $\mathrm{K}$ utilizando-se da técnica escalonada regressiva, sendo 0 instrumento de memória a lima no 40. Após a confecção do degrau apical, iniciouse o recuo programado para cervical, onde a cada aumento de calibre do instrumento recuava-se $1 \mathrm{~mm}$, até finalizar com a lima oㅜ 60 .

Após a instrumentação e irrigação final com soro fisiológico, as raízes foram divididas aleatoriamente em 3 grupos, com 18 raízes em cada grupo, em função dos tratamentos a que, posteriormente, foram submetidas as paredes dos canais.

Assim, foram formados os seguintes grupos:

\section{Grupo I}

Aplicação de EDTA*, preenchendo os canais radiculares e agitação do mesmo com o instrumento de memória, permanecendo por 5 minutos. Após esse tempo os canais foram irrigados com soro fisiológico.

\section{Grupo II}

Aplicação de laser de $\mathrm{Nd}$ : YAG ${ }^{* *}$ (Figura 5) com os seguintes parâmetros: $15 \mathrm{~Hz}, 100 \mathrm{~mJ}$ e 1,5 Watts com o tempo de 7 segundos com movimentos helicoidais de apical para cervical, quatro repetições, totalizando 28 segundos. 


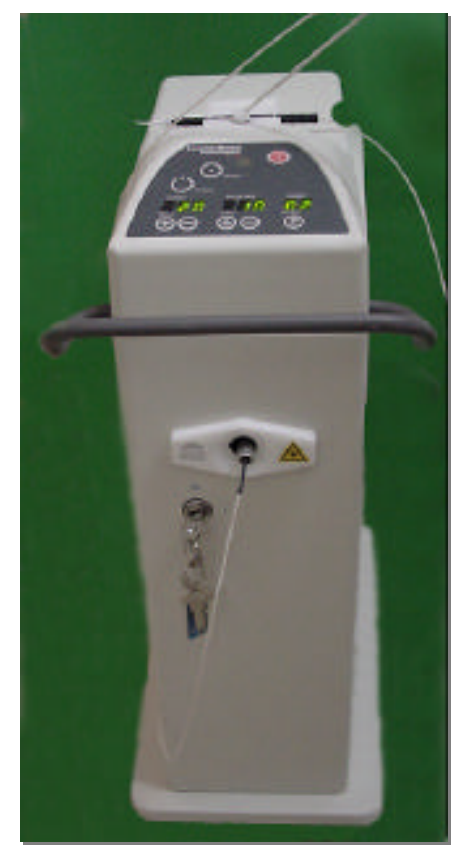

Figura 5 - Aparelho de laser de Nd:YAG

\section{Grupo III}

Aplicação de EDTA por 5 minutos nos canais radiculares e agitação com o instrumento de memória nos moldes do Grupo I. Após esse tempo os canais foram irrigados com soro fisiológico e secos com cone de papel absorvente. Terminado esse procedimento foi aplicado laser de Nd: YAG, conforme o Grupo II.

Das 18 raízes, três foram preparadas para análise ao microscópio eletrônico de varredura e as 15 restantes tiveram os canais obturados. 
As 45 raízes tiveram seus canais obturados pela técnica Híbrida de Tagger, usando o cimento AH Plus*.

Após a escolha do cone de guta-percha** principal e preparo do cimento obturador, conforme as especificações do fabricante, iniciouse a obturação assentando o cone principal ao longo do canal radicular pela técnica controlada, isto é, o cone, com exceção da extremidade apical, foi envolto pelo cimento obturador e levado ao canal radicular em um só movimento de introdução. Com uma lima do tipo $\mathrm{K}$ no 30 foi feita condensação lateral no terço apical, colocando-se de dois a três cones acessórios ${ }^{\star *}$. A seguir, um compactador guta-condensor ${ }^{\star \star \star} n^{\circ}$ 50, acoplado a um contra ângulo foi introduzido no canal até encontrar resistência à sua penetração, acionoutse o contra ângulo à velocidade máxima e o compactador foi levado em direção apical até quatro milímetros aquém do degrau apical de instrumentação, permanecendo nessa posição por mais ou menos 1 segundo, aliviando-se a pressão sobre o mesmo ele foi retirado do canal, compactando, assim, os materiais obturadores apical e lateralmente.

A condensação vertical manual e o corte da obturação foram feitas com condensadores de Paiva aquecidos, deixando-se de dois a três milímetros de extensão cervical do canal sem material obturador, que foi selada com Cimpat ${ }^{\star \star \star *}$.

Após a obturação, foram feitas tomadas radiográficas das raízes para futura análise da obturação dos canais laterais artificiais.

As raízes foram posicionadas no sentido vestíbulo-lingual sobre filmes radiográficos periapicais da marca Kodak Insight ${ }^{\star * * \star *}$, e então, radiografadas com o tempo de exposição de 0,6 segundo com a distância foco/filme de 40 centímetros.

As películas foram processadas utilizando-se o método temperatura/tempo ${ }^{91}$. O tempo de revelação foi de 4 minutos com o revelador à

\footnotetext{
*Dentsply - Alemanha

${ }^{* *}$ Tanari - Manacapuru, Brasil

***Maillefer - Ballaigues, Suíça

**** Septodont - Paris, França

${ }^{\star \star \star \star \star *}$ Kodak - Rochester, Nova York, EUA
} 
temperatura de $20^{\circ} \mathrm{C}$, lavagem intermediária por 10 segundos, fixação por 10 minutos com lavagem final por 20 minutos em água corrente e secagem por 20 minutos em estufa apropriada.

A análise da obturação ou não dos canais laterais foi feita por observações das imagens radiográficas.

As radiografias foram escaneadas e, com o recurso do programa Digora, o preenchimento dos canais laterais foi analisado atribuindo a ele os seguintes escores:

$0=$ preenchimento completo

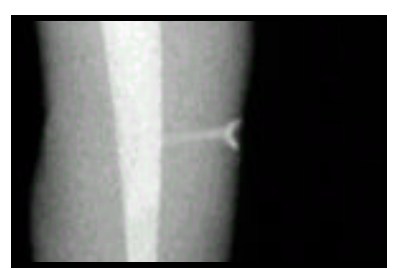

Figura 6 - Imagem radiográfica que representa o escore 0

$0,5=$ preenchimento pela metade e/ou presença de bolhas

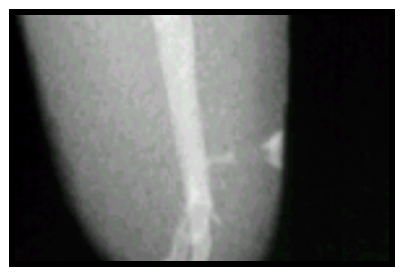

Figura 7 - Imagem radiográfica que representa o escore 0,5

$1=$ material obturador apenas nas paredes do canal lateral

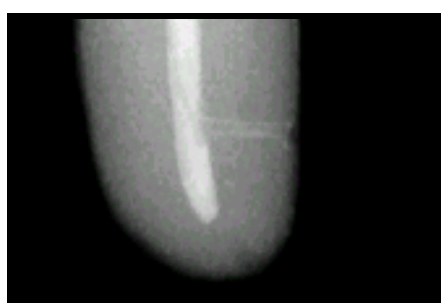

Figura 8 - Imagem radiográfica que representa o escore 1 
2 = material obturador extravasado, com o canal lateral vazio

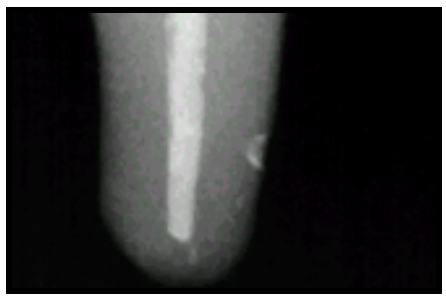

Figura 9 - Imagem radiográfica que representa o escore 2

3 = canal lateral vazio, sem evidências da penetração de material

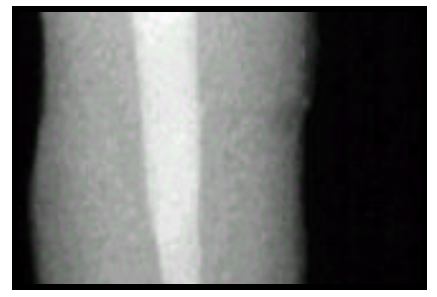

Figura 10 - Imagem radiográfica que representa o escore 3

Os dados obtidos foram submetidos ao teste de Kruskal

Wallis por se tratar de um teste não paramétrico que compara dois ou mais grupos e por ser uma análise subjetiva.

Nas raízes reservadas para a observação ao microscópio eletrônico de varredura foram confeccionados sulcos longitudinais nas faces vestibular e lingual, aprofundando-os até as proximidades dos canais principais. Com uma espátula Le Cron realizou-se a clivagem das raízes, obtendo-se duas hemipartes proximais, uma delas contendo os canais laterais artificiais. Estas hemipartes foram montadas em bases metálicas e levadas ao metalizador Hummer VII para a metalização em uma espessura de 7 milímetros.

Os espécimes metalizados foram então levados ao microscópio eletrônico de varredura JEOL, modelo JSMT 220 A fazendo-se então fotomicrografias com a câmera Mamya acoplada ao aparelho, utilizando o filme NEOPAN 120 SS, com aumentos de 150x e 1000x. 
De posse dessas fotomicrografias analisou-se a superfície dentinária quanto à sua forma (normal ou com fusão) presença de "smear layer" e as condições das embocaduras dos canais laterais artificiais (seladas ou não). 


\section{5- Resultados}




\section{5- Resultados}

A tabela 1 acolhe os valores dos escores referentes ao Grupo I.

\section{Tabela 1}

\begin{tabular}{c|c|c|c}
\hline \multicolumn{5}{|c}{ GRUPO I } \\
\hline Dentes & Terço cervical & Terço médio & Terço apical \\
\hline 1 & 0 & 0 & 3 \\
\hline 2 & 0 & 0 & 1 \\
\hline 3 & 0,5 & 0,5 & 0 \\
\hline 4 & 0,5 & 0 & 3 \\
\hline 5 & 0,5 & 3 & 2 \\
\hline 6 & 0 & 0 & 0,5 \\
\hline 7 & 0 & 0 & 2 \\
\hline 8 & 3 & 0 & 2 \\
\hline 9 & 0,5 & 0,5 & 0,5 \\
\hline 10 & 0 & 0 & 0,5 \\
\hline 11 & 0 & 0 & 0 \\
\hline 12 & 0 & 0 & 0 \\
\hline 13 & 0,5 & 0,5 & 2 \\
\hline 14 & 0,5 & 0 & 3 \\
\hline 15 & 0,5 & 0 & \\
\hline
\end{tabular}

Tabela 1- Valores dos escores referentes aos terços dos dentes do Grupo I. 
A tabela 2 acolhe os valores dos escores referentes ao

Grupo II.

Tabela 2

\begin{tabular}{c|c|c|c}
\hline \multicolumn{5}{|c}{ GRUPO II } \\
\hline Dentes & Terço cervical & Terço médio & Terço apical \\
\hline 1 & 0,5 & 3 & 0,5 \\
\hline 2 & 0,5 & 0 & 2 \\
\hline 3 & 0 & 0 & 0,5 \\
\hline 4 & 3 & 0 & 0,5 \\
\hline 5 & 0 & 0 & 3 \\
\hline 6 & 0,5 & 0,5 & 2 \\
\hline 7 & 0,5 & 0 & 2 \\
\hline 8 & 0,5 & 0 & 2 \\
\hline 9 & 0 & 0 & 0 \\
\hline 10 & 0,5 & 0 & 1 \\
\hline 11 & 0 & 3 & 2 \\
\hline 12 & 0,5 & 0 & 3 \\
\hline 13 & 0 & 0 & 3 \\
\hline 14 & 3 & 3 & 3 \\
\hline 15 & 0,5 & 2 & 1 \\
\hline
\end{tabular}

Tabela 2- Valores dos escores referentes aos terços dos dentes do Grupo II. 
A tabela 3 acolhe os valores dos escores referentes ao

Grupo III.

Tabela 3

\begin{tabular}{c|c|c|c}
\hline \multicolumn{4}{|c}{ GRUPO III } \\
\hline Dentes & Terço cervical & Terço médio & Terço apical \\
\hline 1 & 0 & 0 & 3 \\
\hline 2 & 0,5 & 0 & 0,5 \\
\hline 3 & 0 & 0,5 & 2 \\
\hline 4 & 0 & 0 & 0,5 \\
\hline 5 & 0 & 0 & 0,5 \\
\hline 6 & 0 & 0 & 0,5 \\
\hline 7 & 3 & 0 & 1 \\
\hline 8 & 0 & 0 & 0,5 \\
\hline 9 & 0,5 & 0,5 & 3 \\
\hline 10 & 0,5 & 0 & 0,5 \\
\hline 11 & 3 & 0 & 2 \\
\hline 12 & 2 & 0 & 0 \\
\hline 13 & 3 & 0 & 2 \\
\hline 14 & 3 & 0 & 0 \\
\hline 15 & 0 & 0 & \\
\hline
\end{tabular}

Tabela 3- Valores dos escores referentes aos terços dos dentes do Grupo III. 
A tabela 4 acolhe os dados referentes ao preenchimento dos canais laterais em função dos grupos experimentais, nos quais não se detectou diferença estatisticamente significante $(p>0,05)$.

Tabela 4

\begin{tabular}{c|c|c|c}
\hline Grupo & Soma de Postos & Posto Médio & Número \\
\hline EDTA & 2983,5 & 66,30 & 45 \\
\hline Laser de Nd:YAG & 3453,0 & 76,73 & 45 \\
\hline $\begin{array}{c}\text { EDTA + Laser de } \\
\text { Nd:YAG }\end{array}$ & 2743,5 & 60,97 & 45 \\
\hline
\end{tabular}

Tabela 4 - Soma dos Postos Médios em função dos escores atribuídos aos canais laterais artificiais,obturados ou não, de acordo com o tratamento efetuado nas paredes dos canais radiculares (grupos experimentais), nos três terços radiculares.

A tabela 5 acolhe os dados referentes ao preenchimento dos canais laterais, do terço cervical, em função dos grupos experimentais, nos quais não foi detectada diferença estatisticamente significante $(p>0,05)$.

\section{Tabela 5}

\begin{tabular}{c|c|c|c}
\hline Grupo & Soma de Postos & Posto Médio & Número \\
\hline EDTA & 308,0 & 20,53 & 15 \\
\hline Laser de Nd:YAG & 348,0 & 23,20 & 15 \\
\hline $\begin{array}{c}\text { EDTA + Laser de } \\
\text { Nd:YAG }\end{array}$ & 379,0 & 25,27 & 15 \\
\hline
\end{tabular}

Tabela 5 - Soma dos Postos Médios, em função dos escores atribuídos aos canais artificiais, obturados ou não,de acordo com os tratamentos efetuados nas paredes dos canais radiculares (grupos experimentais), apenas no terço cervical.

A tabela 6 acolhe os dados referentes ao preenchimento dos canais laterais do terço médio, em função dos grupos experimentais, nos quais não foi detectada diferença estatisticamente significante $(p>0,05)$. 
Tabela 6

\begin{tabular}{c|c|c|c}
\hline Grupo & Soma de Postos & Posto Médio & Número \\
\hline EDTA & 365,5 & 24,37 & 15 \\
\hline Laser de Nd:YAG & 378,5 & 25,23 & 15 \\
\hline $\begin{array}{c}\text { EDTA + Laser de } \\
\text { Nd:YAG }\end{array}$ & 291,0 & 19,40 & 15 \\
\hline
\end{tabular}

Tabela 6 - Soma dos Postos Médios, em função dos escores atribuídos aos canais artificiais, obturados ou não, de acordo com os tratamentos efetuados nas paredes dos canais radiculares (grupos experimentais), apenas no terço médio.

A tabela 7 acolhe os dados referentes ao preenchimento dos canais laterais do terço apical, em função dos grupos experimentais, nos quais não foi detectada diferença estatisticamente significante $(p>0,05)$.

Tabela 7

\begin{tabular}{c|c|c|c}
\hline Grupo & Soma de Postos & Posto Médio & Número \\
\hline EDTA & 364,5 & 24,30 & 15 \\
\hline Laser de Nd:YAG & 401,5 & 26,77 & 15 \\
\hline $\begin{array}{c}\text { EDTA + Laser de } \\
\text { Nd:YAG }\end{array}$ & 269,0 & 17,93 & 15 \\
\hline \multicolumn{2}{c}{ Tabela 7 - Soma dos Postos Médios, em função dos escores atribuídos aos canais artificiais, }
\end{tabular}
obturados ou não, de acordo com os tratamentos efetuados nas paredes dos canais radiculares (grupos experimentais), apenas no terço apical.

O Gráfico I representa os valores referentes aos postos médios representativos do preenchimento dos canais laterais em função dos grupos experimentais, independente do terço analisado. 


\section{Gráfico 1}

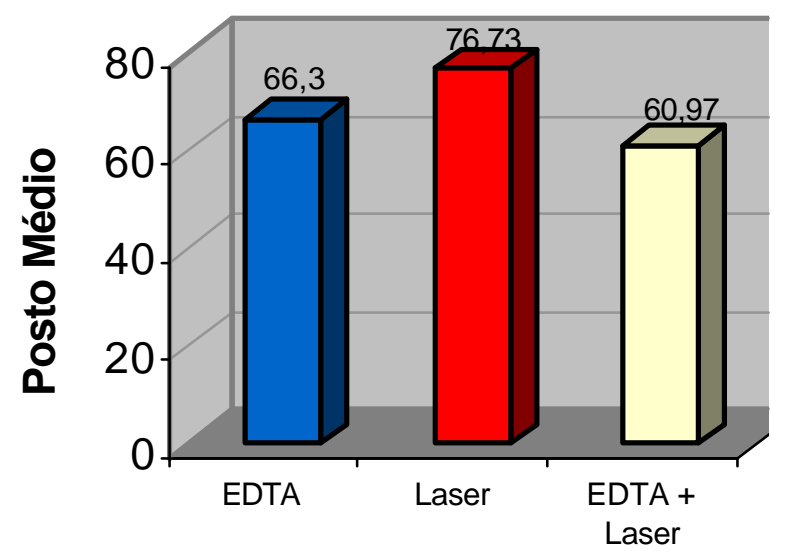

Figura 11 - Gráfico representativo dos postos médios obtidos em função dos escores atribuídos à obturação ou não dos canais laterais, independentemente do terço analisado.

O Gráfico II representa os valores referentes aos postos médios em relação aos grupos, separados por terços:

\section{Gráfico II}

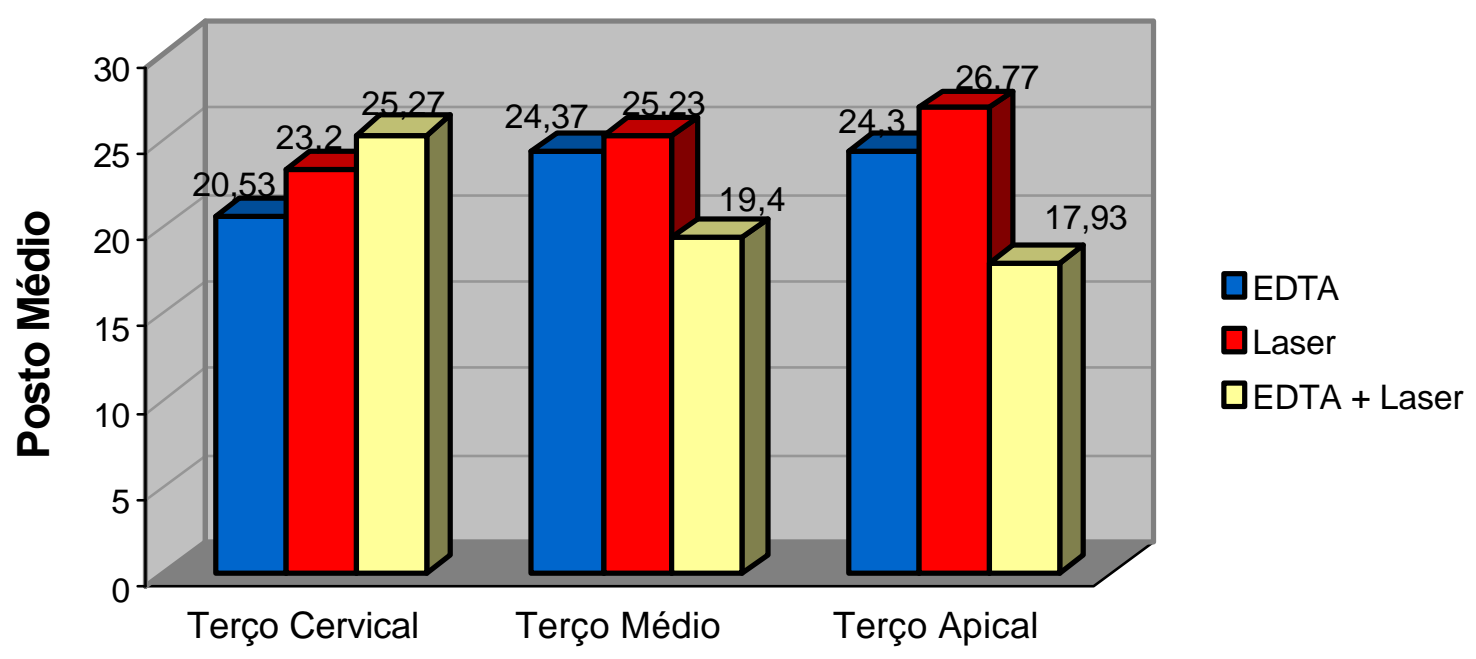

Figura 12 - Gráfico representativo dos postos médios obtidos em função dos escores atribuídos à obturação ou não dos canais laterais, considerando os terços: cervical, médio e apical . 
As figuras que se seguem representam a análise realizada nas paredes dentinárias e embocaduras dos canais laterais artificiais por meio do microscópio eletrônico de varredura.

\section{Grupo 1 - EDTA}

A figura 13 mostra a embocadura do canal lateral artificial localizado no terço cervical. Pode se observar limpeza e integridade da embocadura.

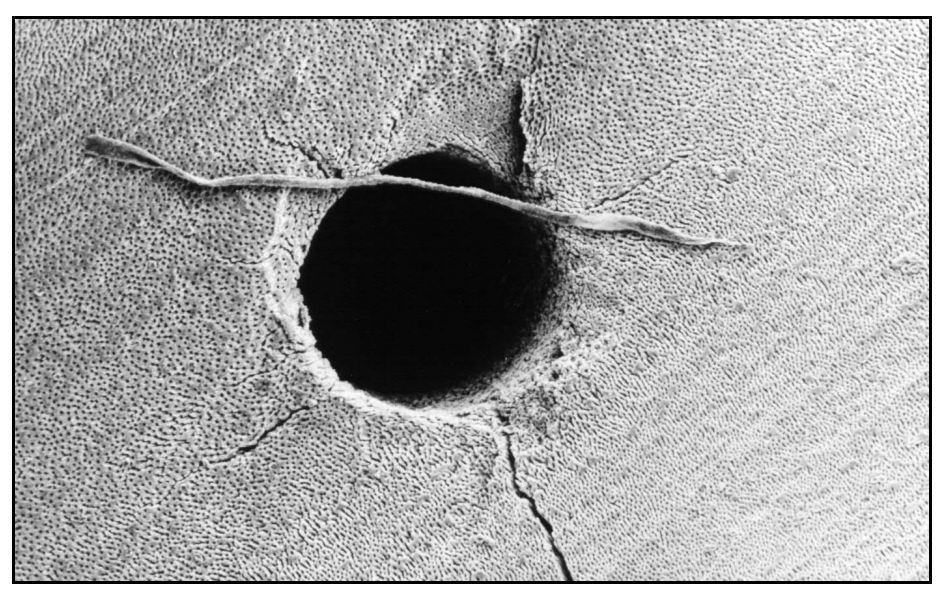

Figura 13 - Fotomicrografia da embocadura do canal lateral artificial no terço cervical - aumento de $150 x$.

A figura 14 mostra uma parte da parede dentinária localizada no terço cervical. Observa-se uma eficiente limpeza e integridade na parede com túbulos dentinários abertos. 


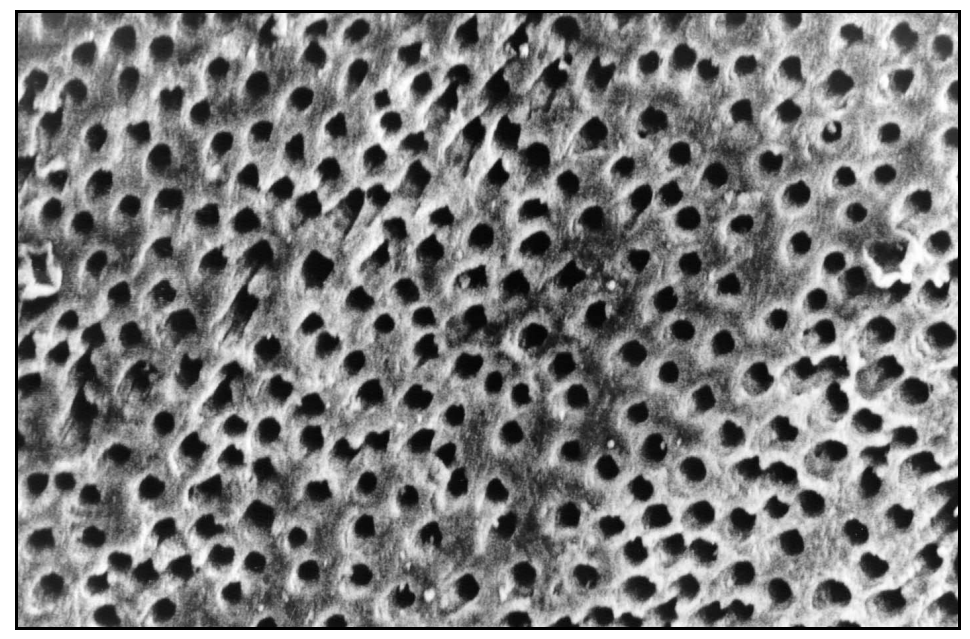

Figura 14 - Fotomicrografia de uma parte da parede do canal radicular, referente ao terço cervical - aumento de 1000x.

A figura 15 mostra a embocadura do canal lateral artificial localizado no terço médio. Pode se observar limpeza e integridade da embocadura.

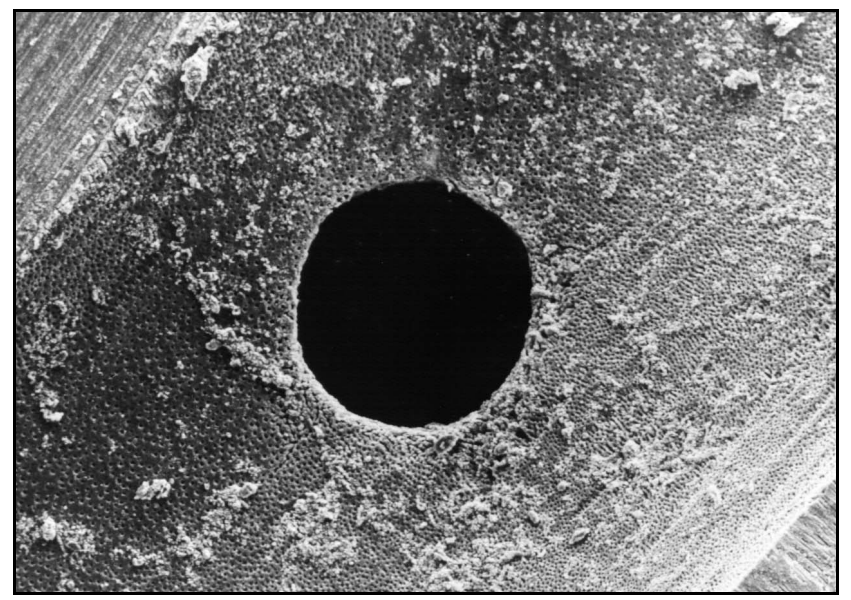

Figura 15 - Fotomicrografia da embocadura do canal lateral artificial no terço médio - aumento de $150 x$.

A figura 16 mostra parte da parede dentinária localizada no terço médio. Observa-se uma limpeza, com pequenas áreas de "smear layer" e integridade da parede com túbulos abertos. 


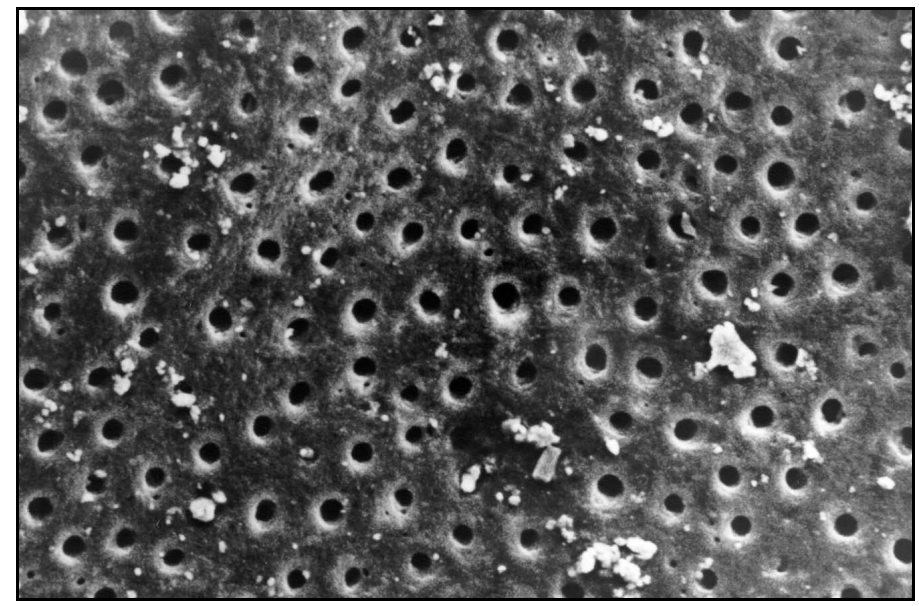

Figura 16 - Fotomicrografia de parte da parede do canal radicular, referente ao terço médio aumento de $1000 x$.

A figura 17 mostra a embocadura do canal lateral artificial localizado no terço apical. Pode-se observar limpeza e integridade da embocadura mas, na parede, ao redor do canal, nota-se presença de uma certa quantidade de "smear layer".

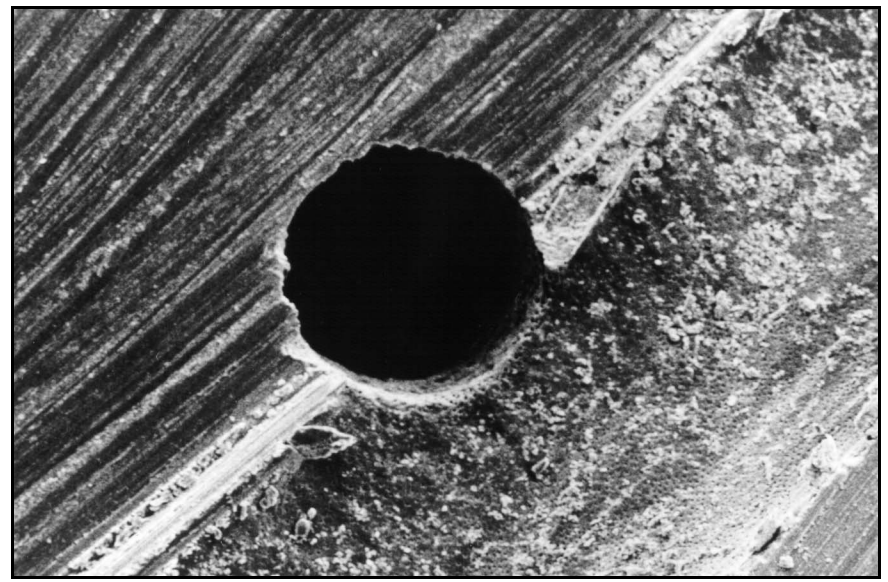

Figura 17 - Fotomicrografia da embocadura do canal lateral artificial no terço apical - aumento de 150x.

A figura 18 mostra parte da parede do canal localizada no terço apical. Observa-se a presença de "smear layer", porém, com uma razoável quantidade de túbulos abertos. 


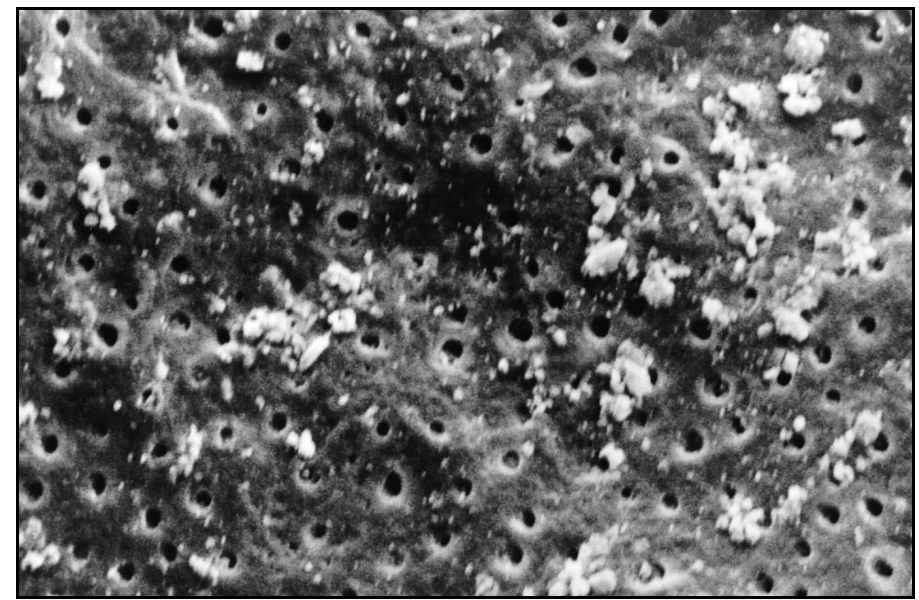

Figura 18 - Fotomicrografia de parte da parede do canal radicular, referente ao terço apical aumento de $1000 x$.

\section{Grupo 2 - Laser de Nd:YAG}

A figura 19 mostra a embocadura do canal lateral artificial localizado no terço cervical. Pode se observar a presença de "smear layer" na parede dentinária e uma pequena porção na embocadura.

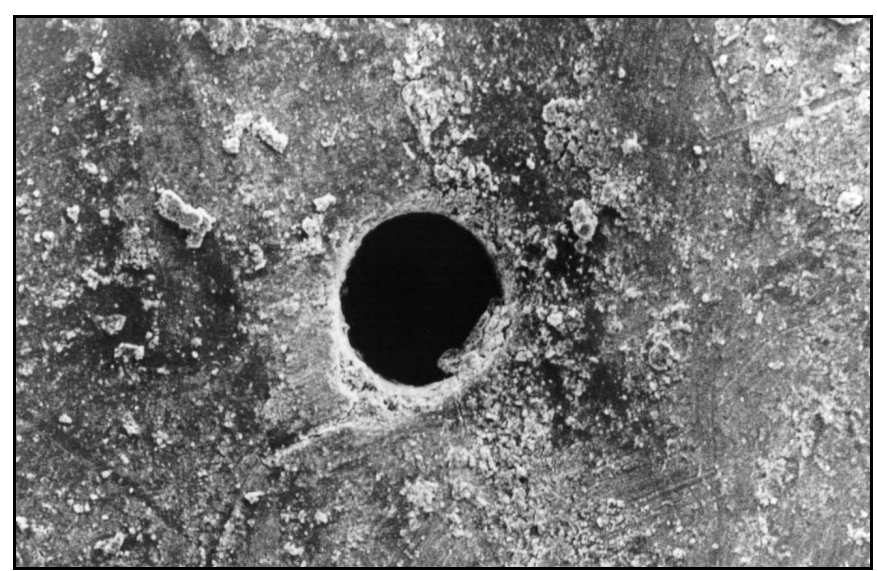

Figura 19 - Fotomicrografia da embocadura do canal lateral artificial no terço cervical - aumento de $150 x$.

A figura 20 mostra parte da parede dentinária localizada no terço cervical. Observa-se presença de grande quantidade de "smear layer", com aspecto granuloso e amorfo. Em algumas áreas essa "smear layer" tem 
aspecto de derretida e ressolidificada. Não são observados túbulos dentinários, que foram obliterados pela dentina fundida.

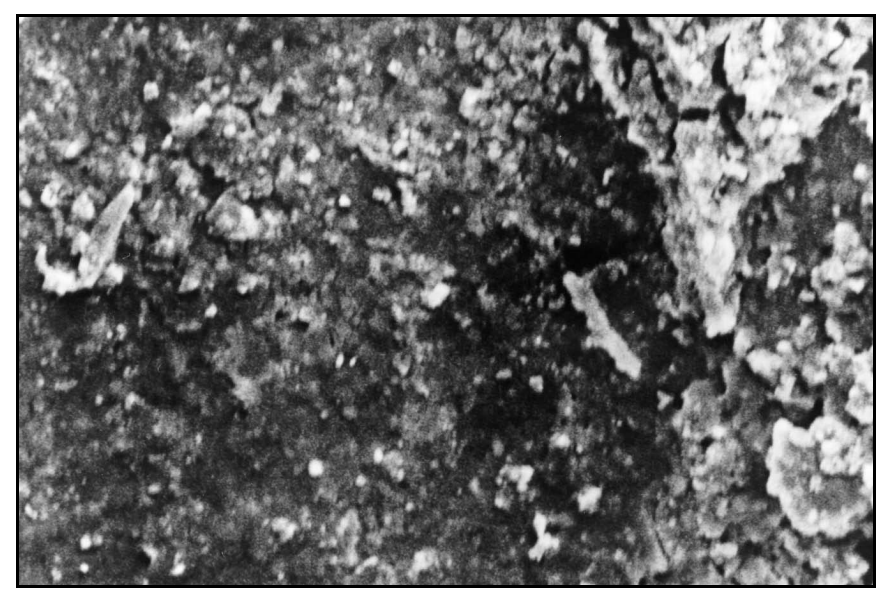

Figura 20 - Fotomicrografia de parte da parede dentinária do canal radicular, referente ao terço cervical - aumento de 1000x.

A figura 21 mostra a embocadura do canal lateral artificial localizado no terço médio. Pode se observar a presença de "smear layer" nas paredes, mas a embocadura está limpa.

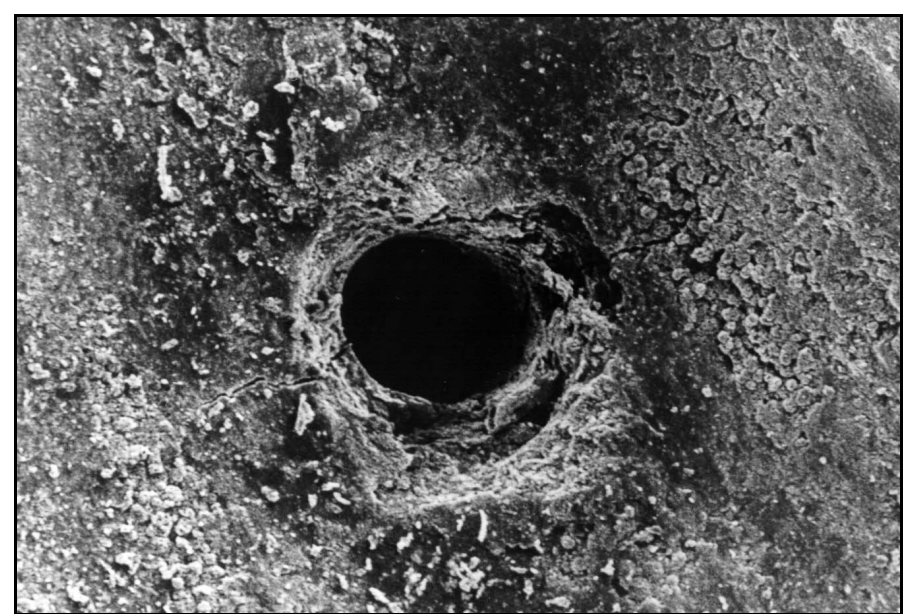

Figura 21 - Fotomicrografia da embocadura do canal lateral artificial no terço médio - aumento de $150 x$.

A figura 22 mostra parte da parede dentinária localizada no terço médio. Observa-se presença de "smear layer" em grande quantidade, 
com aspecto granuloso e amorfo. Em algumas áreas essa "smear layer" tem aspecto de derretida e ressolidificada. Não são observados túbulos dentinários, que foram obliterados.

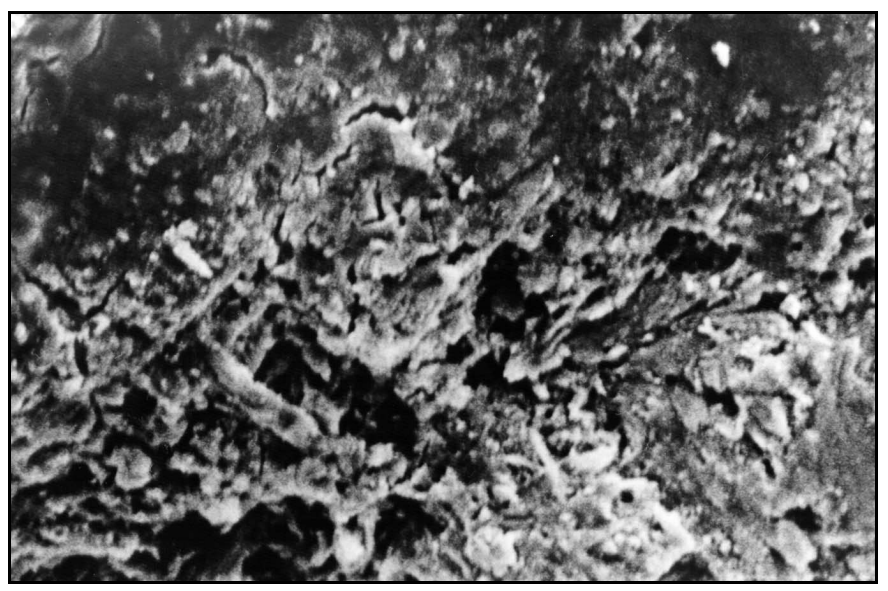

Figura 22 - Fotomicrografia de parte da parede do canal radicular, referente ao terço médio aumento de 1000x.

A figura 23 mostra a embocadura do canal lateral artificial localizado no terço apical. Pode se observar a presença de "smear layer" nas paredes e a embocadura parcialmente obstruída por "smear layer".

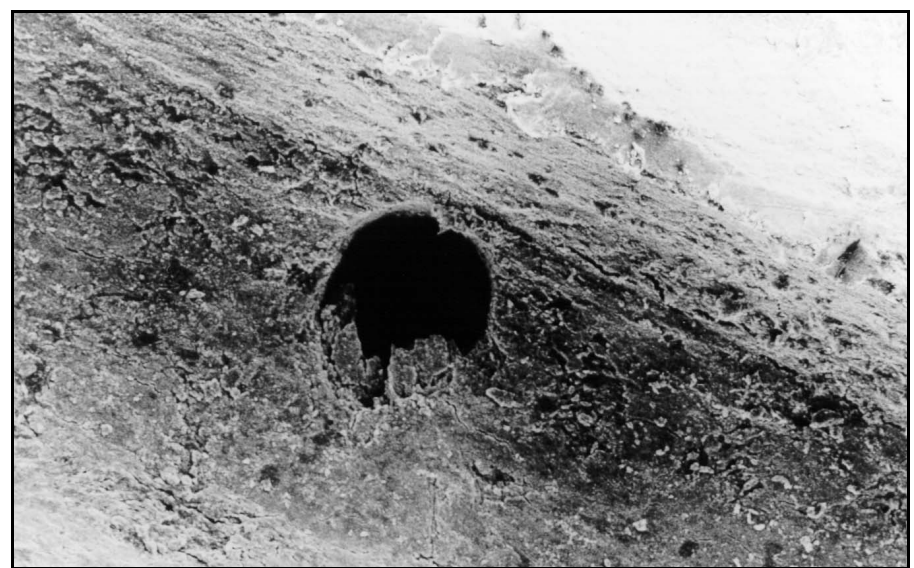

Figura 23 - Fotomicrografia da embocadura do canal lateral artificial no terço apical - aumento de 150x.

A figura 24 mostra parte da parede dentinária localizada no terço apical. Observa-se presença de grande quantidade de "smear layer", 
com aspecto granuloso e amorfo. Em algumas áreas essa "smear layer" tem aspecto de derretida e ressolidificada. Não se observam túbulos dentinários, que foram obliterados.

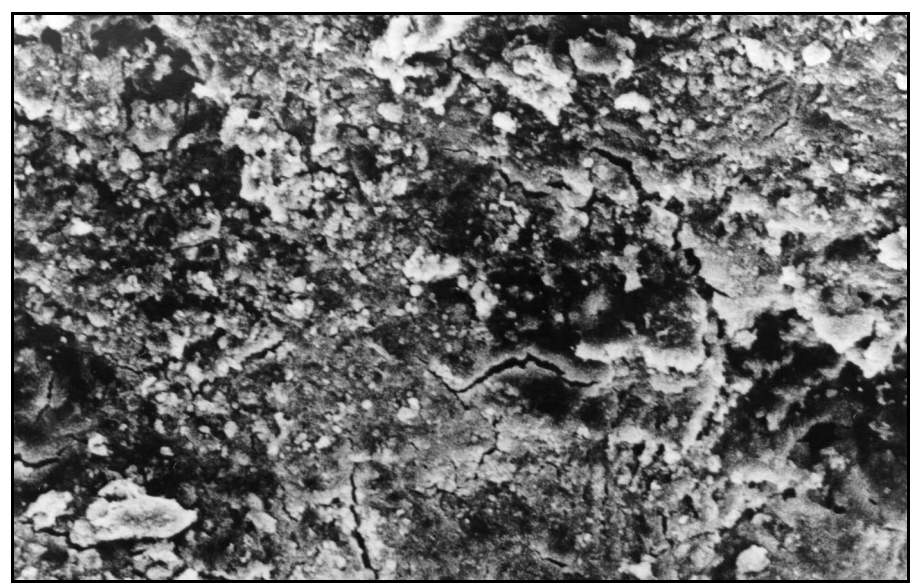

Figura 24 - Fotomicrografia de parte da parede do canal radicular, referente ao terço apical aumento $1000 x$

\section{Grupo 3 - EDTA + Laser de Nd:YAG}

A figura 25 mostra a embocadura do canal lateral artificial localizado no terço cervical que se encontra limpa e desobstruída.

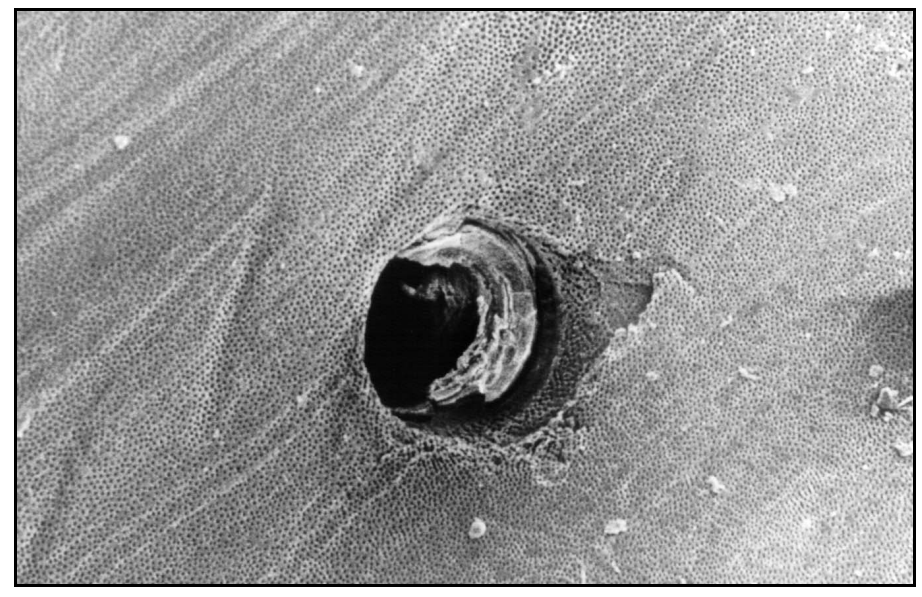

Figura 25 - Fotomicrografia da embocadura do canal lateral artificial no terço cervical - aumento de $150 x$.

A figura 26 mostra uma parte da parede dentinária localizada no terço cervical. Os túbulos dentinários estão expostos e a parede apresenta um aspecto normal. 


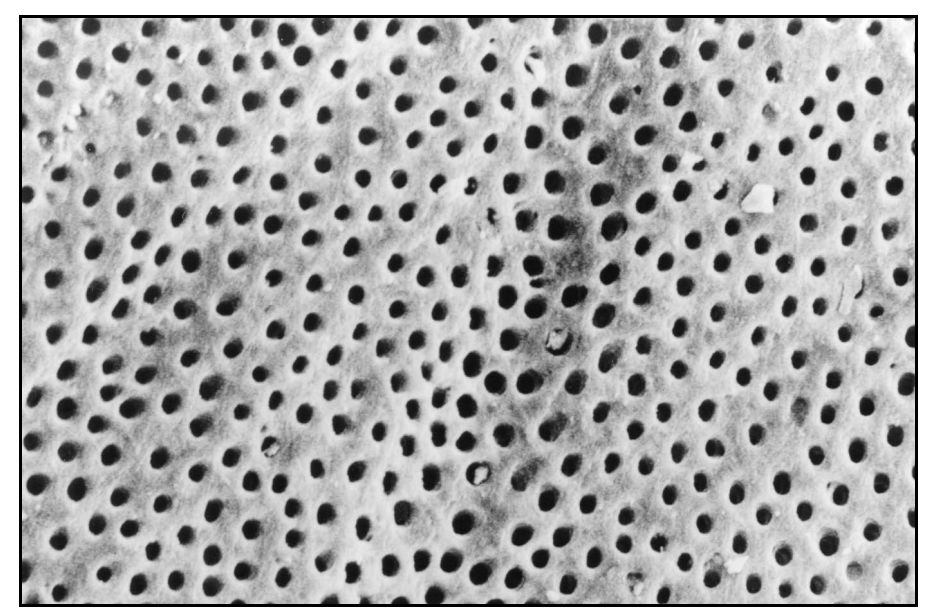

Figura 26 - Fotomicrografia de parte da parede do canal radicular, referente ao terço cervical aumento de 1000x.

A figura 27 mostra a embocadura do canal lateral artificial localizado no terço médio. Esta se encontra limpa e desobstruída, quase que totalmente. Observa-se integridade nas bordas da embocadura.

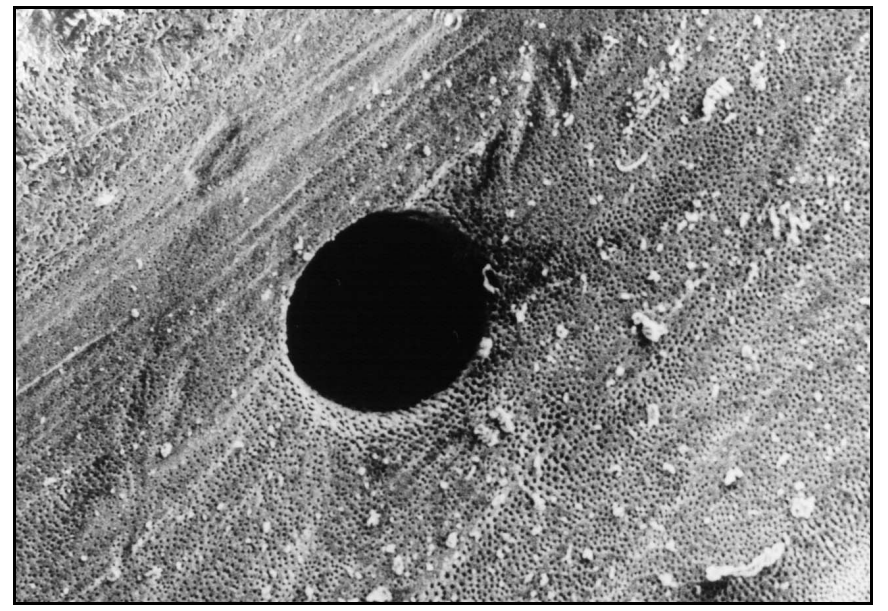

Figura 27 - Fotomicrografia da embocadura do canal lateral artificial no terço médio - aumento de $150 x$.

A figura 28 mostra a parede dentinária na região do terço médio. Os túbulos dentinários estão expostos, porém, nota-se a presença de uma quantidade mínima de "smear layer". 


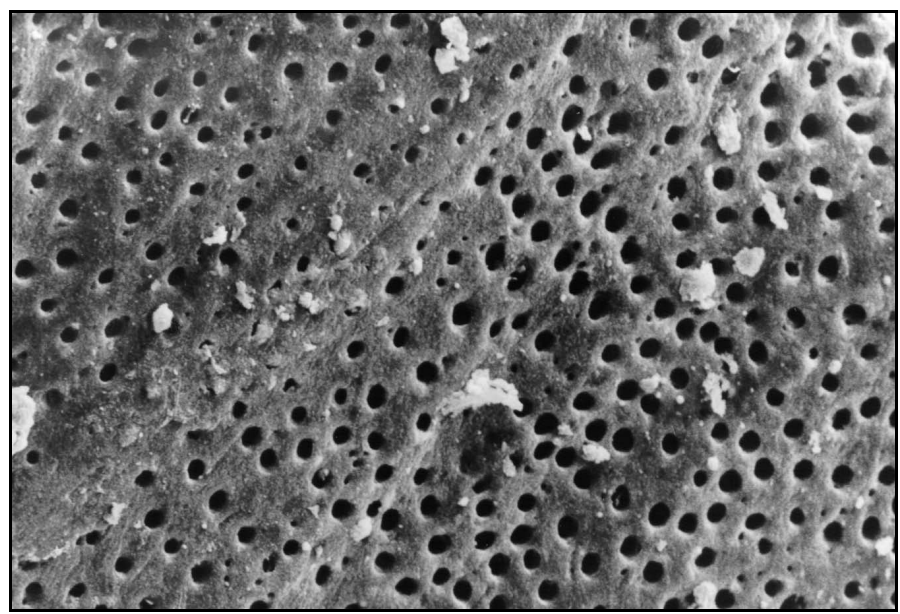

Figura 28 - Fotomicrografia de parte da parede do canal radicular, referente $\boldsymbol{\infty}$ terço médio aumento de 1000x.

A figura 29 mostra a embocadura do canal lateral artificial localizado no terço apical. A embocadura se encontra obstruída por "smear layer".

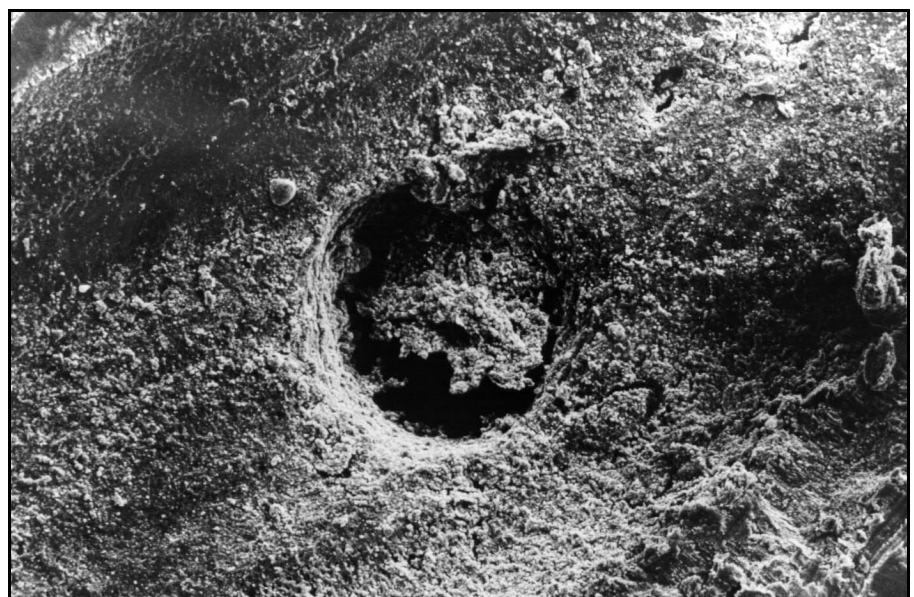

Figura 29 - Fotomicrografia da embocadura do canal lateral artificial no terço apical - aumento de $150 x$.

A figura 30 mostra parte da parede dentinária localizada no terço apical. Observa-se a presença de "smear layer" e uma mudança na estrutura dentinária da parede do canal. A "smear layer" apresenta um aspecto granuloso, amorfo e derretido. Os túbulos dentinários estão todos obliterados e não são visíveis. 


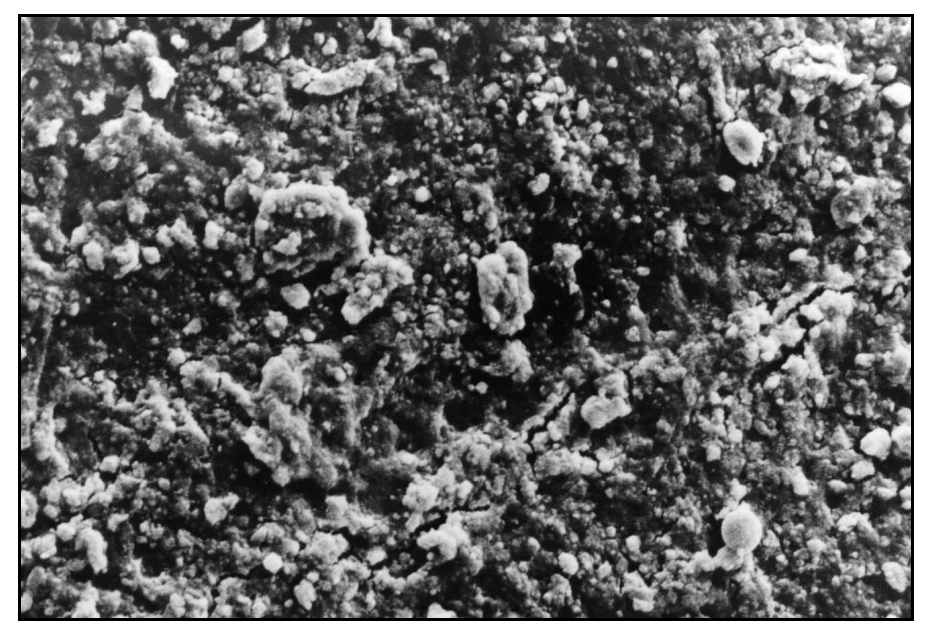

Figura 30 - Fotomicrografia de parte da parede do canal radicular, referente ao terço apical aumento de 1000x. 
6- Discussão 


\section{6- Discussão}

\section{1- Discussão da metodologia}

Para este estudo foram utilizados os $1^{\text {os }}$ pré-molares inferiores extraídos, em detrimento de outros grupos por se tratar de dentes que, ainda, podem ser encontrados em boas condições e em número suficiente para realização do experimento. Todavia, o principal motivo da escolha desse tipo de dente foi o fato dele apresentar um alto índice de raiz única com um único canal. Segundo PUCCI; REIG ${ }^{82}, 84,2 \%$ dos primeiros pré-molares inferiores possuem 1 raiz e 1 canal.

Os canais laterais foram confeccionados nos terços cervical, médio e apical, e, mesmo não sendo classificado como lateral quando está localizado no terço apical ${ }^{82}$, ele assim o foi chamado para facilitar a compreensão. Apesar da maior incidência de canais laterais ocorrer no terço apical $(74,0 \%)^{26}$, a confecção nos outros terços também foi realizada, apesar da suas incidências serem baixas (terço médio 10,3\% e terço cervical 4,7\%) ${ }^{26}$. Contudo, eles existem. Segundo WEINE ${ }^{95}$ o número de canais laterais é muito maior do que aqueles que são realmente obturados e observados nas radiografias.

A confecção dos canais laterais com diâmetro referente a um alargador 15 foi baseada nos trabalhos de GOLDBERG; ARTAZA; De SILVIO ${ }^{42,43}$. Em adição, após examinar 180 dentes portadores de canais laterais naturais por meio de um estereomicroscópio Moraes chegou à conclusão que a grande maioria dos canais laterais tinha o calibre correspondente ao diâmetro de uma lima do tipo $K$ no 15 . Para o preparo dos canais laterais, GOLDBERG; ARTAZA; De SILVIO ${ }^{42,} 43$ utilizaram alargadores de diâmetro o 15 adquiridos comercialmente. Diante das dificuldades de se adquirir tais alargadores, optoutse

*Comunicação pessoal 
pela confecção de instrumentos que pudessem servir para o propósito, não fugindo aos preceitos estabelecidos.

De uma maneira geral, os instrumentos rotatórios não apresentam guia de penetração capaz de perfurar a dentina, à guisa de uma broca. Já, os instrumentos manuais de aço inoxidável que apresentam guia de penetração ativa, também deixa a desejar para este propósito. Assim, para o preparo de canais nas paredes dentinárias há necessidade de instrumentos com boa capacidade perfurante. Partindo-se da experiência de que o corte em chanfrado de um instrumento endodôntico, oferece-lhe grande capacidade perfurante, escolheurse a lima manual do tipo $\mathrm{K} n-10$, a qual foi seccionada, em chanfrado, a 2,5mm de sua extremidade tornando-a um instrumento perfurante de diâmetro equivalente a uma lima do tipo $\mathrm{K}$ no 15 , devido à sua padronização seguir as normas da ISO (Taper 0,02). Para que seu uso pudesse ser feito mecanicamente, em contra-ângulo comum, o cabo foi cortado, aplicando-se resina acrílica para possibilitar o encaixe no contra-ângulo (Figura 2).

Após a confecção dos canais laterais realizou-se a instrumentação dos canais radiculares principais. Esta foi semelhante à realizada por GOLDBERG; ARTAZA; De SILVIO ${ }^{42,}{ }^{43}$ que utilizaram brocas de Gattes Glidden nos terços médio e cervical e instrumentação manual com limas do tipo $\mathrm{K}$ no terço apical.

A instrumentação do canal radicular, além de remover restos necróticos e dar formato cônico ao canal radicular, desgastando as paredes dentinárias produz a chamada "smear layer" que pode obliterar as embocaduras dos canais laterais artificiais. $\mathrm{O}$ uso das brocas de Gattes Glidden produz mais raspas de dentina e conseqüentemente podem produzir mais "smear layer"33 e segundo DAMETTO et al. ${ }^{24}$ comparando a limpeza do canal radicular após a instrumentação manual ou com instrumentos rotatórios, notaram, no terço apical, maior quantidade de "smear layer" após instrumentação manual. Provavelmente devido ao seu "design", os instrumentos rotatórios ao serem ativados dentro do canal radicular, fazem com que as raspas de dentina sejam eliminadas via coronária. 
A cada troca de instrumento optourse pela irrigação com hipoclorito de sódio a 1\%. O hipoclorito é um composto halogenado, rotineiramente usado na Endodontia. Devido à sua baixa tensão superficiap, 61, 101 pode penetrar em reentrâncias das paredes do canal, além de suas outras propriedades características como: neutralização parcial de produtos tóxicos no interior do canal; tem poder bactericida, pois libera oxigênio e cloro, um dos melhores anti-sépticos encontrados ${ }^{61}$, quando entra em contato com restos orgânicos. Além disso, tem poder dissolvente de matéria orgânica juntamente com a característica de baixa tensão superficial. Na ocorrência de canais laterais, o hipoclorito de sódio é muito importante, pois esses canais possuem restos orgânicos difíceis de serem acessados mecanicamente, e o hipoclorito de sódio, devido às suas propriedades pode atingilos. BAUMGATNER; MADER ${ }^{9}$, GROSSMAN; MEIMAN ${ }^{45}$ e WEINE ${ }^{95}$, entre muitos outros autores demonstraram a eficiência do hipoclorito de sódio em dissolver restos pulpares.

Assim, o hipoclorito de sódio é muito eficiente na remoção da matéria orgânica, entretanto, sobre a parte inorgânica, a qual compõe grande parte da "smear layer", ele não é efetivo.

A substância mais utilizada na Endodontia para limpeza final do sistema de canais radiculares é o EDTA. Ele é um quelante que foi introduzido na Endodontia, em 1957, por OSTBY ${ }^{79}$, segundo o qual promove um efeito amolecedor na dentina, facilita a instrumentação e ajuda na remoção de instrumentos fraturados dentro de canais radiculares; histologicamente não causa nenhum efeito deletério aos tecidos pulpares e periapicais. ${ }^{79}$

A partir de então, vários relatos vêm sendo feitos sobre o uso do EDTA. GOLDBERG; ABRAMOVICH ${ }^{41}$ relataram que a limpeza proporcionada pelo EDTA facilita a ação de curativos de demora, muito importante em casos de necrose pulpar e melhora a capacidade seladora do material obturador. CENGIZ; AKTENER; PISKIN ${ }^{21}$, também pesquisaram a ação do EDTA e comprovaram a sua eficiência na remoção da "smear layer" independentemente da posição dos túbulos dentinários. Assim, a eficiência do EDTA tem sido comprovada em muitos trabalhos da literatura, quanto à sua 
eficiência em remover a "smear layer" 2, 18, 19, 20, 47, 77, 84, 93. Como o EDTA é um produto já consagrado na endodontia fez-se a escolha pelo seu uso.

Optou-se, neste trabalho, pela permanência do EDTA no interior dos canais pelo período de 5 minutos para que a sua ação fosse plena, pois segundo alguns autores, a partir desse tempo a ação do EDTA já se faz sobre a dentina parietal ${ }^{19}, 32$. MORAES ${ }^{70}$ encontrou bons resultados com a aplicação do EDTA pelo período de 2 minutos após a instrumentação, CIUCCHI; KHETTABI; HOLZ 22 observaram remoção da "smear layer" já em 3 minutos e DIEP; BRAMANTE ${ }^{28}$ obtiveram melhores resultados de limpeza quando foi usado o EDTAC durante a instrumentação dos canais, seguido pela aplicação do EDTA, no final da instrumentação, por apenas 1 minuto. A descalcificação promovida por ele é autolimitante ${ }^{32,81}$ e está diretamente relacionada com o tempo de sua permanência dentro do canal radicular. Com o passar do tempo o poder desmineralizador diminui devido à saturação de íons cálcio ${ }^{15}$, sendo a permanência do EDTA dentro do canal por um tempo elevado, inútil, uma vez que a desmineralização se tornaria mínima.

A associação do EDTA com o hipoclorito de sódio torna o processo de irrigação mais eficiente ${ }^{9,21}$ pois tem ação tanto sobre a parte orgânica pela ação do hipoclorito e sobre a parte inorgânica pela ação do EDTA.

A evolução tecnológica tem sido notável nas últimas décadas. O laser é uma dessas evoluções que vem crescendo e despertando a curiosidade e o interesse de clínicos e de pesquisadores. No caso específico deste trabalho o interesse estava em descobrir o seu efeito nas embocaduras de canais laterais e nas paredes dentinárias, com a presença ou não de "smear layer".

Neste trabalho foi usado um laser de alta intensidade, mais especificamente o laser de Nd:YAG que tem em seu meio ativo um cristal sintético de ítrio, alumínio e granada (fórmula química $\mathrm{Y}_{3} \mathrm{Al}_{5} \mathrm{O}_{12}$ ) com íons de neodímio "cravejados" nesse crista ${ }^{52}$. Esse laser é transmitido por meio de uma fibra óptica. A utilizada neste trabalho, possui cerca de $300 \mu \mathrm{m}$ de diâmetro, pois 
o diâmetro da fibra óptica deve ser $100 \mu \mathrm{m}$ menor que o diâmetro do instrumento de memória utilizado no preparo do cana ${ }^{67}$.

O laser de Nd:YAG é bem absorvido por tecidos pigmentados, melanina e hemoglobina ${ }^{58}$, por isso seu uso é intenso em incisões em casos de cirurgias. Por outro lado, sua ação em tecidos dentais sadios é limitada, pois esse laser não é bem absorvido por hidroxiapatita e nem por água ${ }^{58}$. A escolha de um parâmetro se faz importante, pois é ele que influencia de maneira significativa os resultados proporcionados pelo laser.

A temperatura que a estrutura dentinária atinge também está relacionada com a potência e com outros parâmetros do laser como: freqüência, duração de radiação, quantidade de energia. Quanto maiores esses parâmetros mais a temperatura aumenta ${ }^{36,59,96}$. LAN ${ }^{59}$ avaliou a elevação da temperatura da superfície radicular externa no terço apical durante a aplicação do laser de Nd:YAG com diferentes parâmetros e concluiu que com $10 \mathrm{~mJ}$ de energia e 20 p.p.s., $80 \mathrm{~mJ}$ e 25 p.p.s. e $60 \mathrm{~mJ}$ e 30 p.p.s. a temperatura não excedeu $10^{\circ} \mathrm{C}$, limite máximo para não causar dados aos ligamentos periodontais. MISERENDINO et al. ${ }^{68}$, não encontraram diferenças significantes entre grupos onde se utilizou laser ou não, em relação às respostas da polpa e do ligamento periodontal, mesmo utilizando uma potência de 12W. Deve ser ressaltado que, junto à aplicação do laser, foi feita concomitantemente uma refrigeração com água e isso contribuiu para que a temperatura não se elevasse tanto, e não causasse danos as estruturas vivas. Para FRAUNHOFER; ALLE ${ }^{36}$ uma potência de apenas $1 \mathrm{~W}$ a $3 \mathrm{~W}$ já é suficiente para elevar a temperatura, suficientemente para iniciar uma inflamação localizada da polpa. BAHCALL et al. ${ }^{6}$ avaliaram o efeito biológico no ligamento periodontal de dentes onde foi utilizado laser de $\mathrm{Nd}$ :YAG com uma potência de apenas $3 \mathrm{~W}, 25$ p.p.s. por períodos menores que 30 segundos e observaram danos, como necrose de células do ligamento periodontal no primeiro dia, seguido por aumento do número e volume de osteócitos e osteoclastos e, em 30 dias, a presença de anquilose e lise no cemento. 
Esses relatos permitiram escolher para este trabalho, os parâmetros de $1,5 \mathrm{~W}$ de potência, $100 \mathrm{~mJ}$ de energia e $15 \mathrm{~Hz}$ de freqüência pelo tempo de 28 segundos, propostos por Valera*. Além disso, são os mesmos propostos por GUTKNECHT et al. ${ }^{48,49}$.

MISERENDINO; LEVY; RIZOIU ${ }^{69}$, após aplicação do laser, encontraram embocaduras de canais laterais parcialmente obliteradas. Esta ocorrência poderia impedir a perfeita obturação desses canais, e, conseqüentemente, prejudicaria o sucesso do tratamento endodôntico, uma vez que esses canais podem abrigar tecidos necróticos ${ }^{102} \mathrm{e}$, inclusive, bactérias podem ser encontradas nessas ramificações em casos de necrose ${ }^{83}$. Lesões laterais, geralmente, estão relacionadas com a presença de canais laterais que não foram obturados ${ }^{95,}{ }^{102}$, caracterizando lesões endo-periodontais ${ }^{13}$ pois são uma via direta de contaminação da polpa para o periodonto e vice e versa ${ }^{95}$.

A obturação do sistema de canais radiculares deve ser realizada por técnicas que proporcionem uma ocupação de todos os espaços promovendo um selamento hermético de todo o sistema. As técnicas termoplastificadoras têm demonstrado serem eficientes na obturação de canais laterais $\mathbf{s}^{42,95,100 .}$.

Neste trabalho foi utilizada a técnica Híbrida de Tagger, apresentada em 1984, que tem se mostrado muito eficiente na obturação de canais radiculares $^{12,56,71}$.

Essa técnica é eficiente também na obturação de canais laterais, embora não seja a melhor em relação às técnicas que mais obturam canais laterais ${ }^{42}$. Contudo, ela tem a vantagem de ser uma técnica simples, muito fácil de se realizar desde que se tenha um certo treinamento prévio. Também não necessita de aparelhos caros, apenas um compactador, podendo ser acessível à grande maioria dos cirurgiões dentistas.

$\mathrm{O}$ AH Plus é um cimento que possui na sua composição o tungstato de cálcio e foi lançado no comércio em $1997^{30}$. Possui uma consistência 
um tanto fluída resultando daí em um grande escoamento ${ }^{30}$. Essa propriedade influenciou a sua escolha, pois facilitaria a obturação dos menores espaços dos canais laterais. ORTEGA et al. ${ }^{78} 2001$, após testarem vários cimentos concluíram que o AH Plus foi o que melhor obturou os canais laterais.

A avaliação das obturações através das radiografias seguiu a mesma metodologia de GOLDBERG; ARTAZA; De SILVIO ${ }^{42,43}$ e de ORTEGA et al. ${ }^{78}$. Apesar de não oferecer uma visão tridimensional é uma avaliação fácil e confiável uma vez que o desgaste da dentina, necessário para a análise dos canais laterais, poderia remover parte do material obturador, dificultando a análise.

As películas foram reveladas seguindo o método temperatura/tempo sugerido por TAVANO; ESTEVAN ${ }^{91}$. Segundo os autores esse método apresenta a vantagem da não necessidade do exame da película durante o processamento. Como o próprio nome diz o tempo de revelação dependerá da temperatura da solução e essa da temperatura ambiente.

A análise estatística foi feita pelo teste não paramétrico de KRUSKAL WALLIS, pois não havia homogeneidade nas amostras e não passaram no teste de normalidade e por esse teste se tratar de uma análise subjetiva.

\section{2- Discussão dos resultados}

Os resultados encontrados demonstraram que os tratamentos aplicados às paredes dos canais radiculares não interferiram significantemente na obturação de canais laterais artificiais, de uma maneira global (Tabela 4 e Figura 11) ou mesmo quando se analisou cada terço, independentemente (Tabelas 5, 6 e 7 e Figura 12).

A análise das fotomicrografias permitiu visualizar que as embocaduras dos canais laterais artificiais não foram obstruídas por dentina derretida. 
Esses dados contrariam aqueles obtidos por LEVY ${ }^{62} \mathrm{e}$ MISERENDINO; LEVY; RIZOIU ${ }^{69}$ que, além dos túbulos dentinários, encontraram as embocaduras de canais laterais, também, parcial ou completamente obliteradas. Há que ressaltar, entretanto, que a potência utilizada por esses pesquisadores foi bem maior que a utilizada neste trabalho. LEVY ${ }^{62}$ utilizou uma potência de $35 \mathrm{~W}$ e freqüência de $20 \mathrm{~Hz}$. Já, MISERENDINO; LEVY; RIZOIU ${ }^{69}$ usaram a potência de $5 \mathrm{~W}$ e freqüência de $50 \mathrm{~Hz}$. Neste trabalho a potência empregada foi de $1,5 \mathrm{~W}$ e a freqüência de $15 \mathrm{~Hz}$.

A mudança da estrutura da dentina está diretamente relacionada ao aumento da potência do lase ${ }^{25,94}$. Da observação desses fatores, pode-se deduzir que, nos experimentos realizados pelos autores citados, a dentina deve ter derretido o suficiente para obstruir as embocaduras dos canais laterais; fato que não ocorreu neste trabalho, certamente pela menor potência utilizada.

A não obstrução das embocaduras dos canais laterais artificiais permitiu que ocorresse a obturação dos canais laterais na grande maioria dos casos. Alguns canais ficaram parcialmente obturados. Isto talvez possa ser explicado pela entrada de bolhas de ar no momento da realização da técnica obturadora, como ocorreu com VILLEGAS et al. ${ }^{93} \mathrm{e}$, também, pela presença de alguma porção de "smear layer" obliterando parcialmente a luz do canal. (Figuras 31, 32 e 33) 


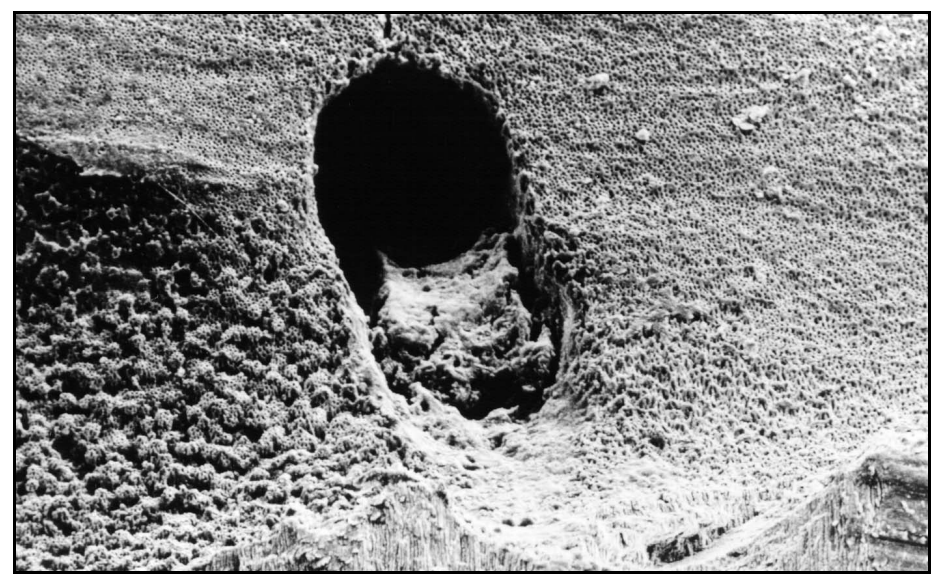

Figura 31- Embocadura de um canal lateral artificial no terço cervical, parcialmente obliterada. Aumento de $150 \mathrm{X}$.

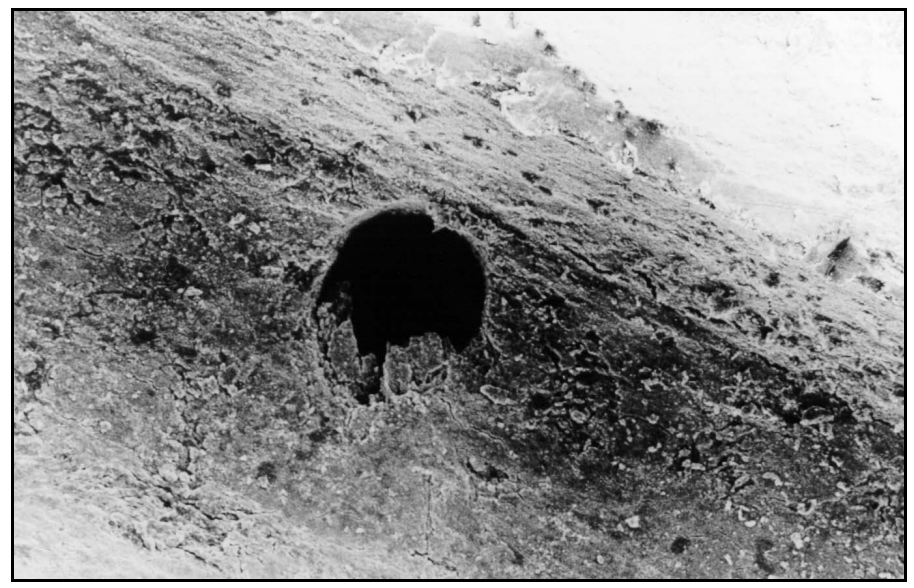

Figura 32- Embocadura de um canal lateral artificial no terço médio parcialmente obliterada. Aumento de $150 \mathrm{X}$. 


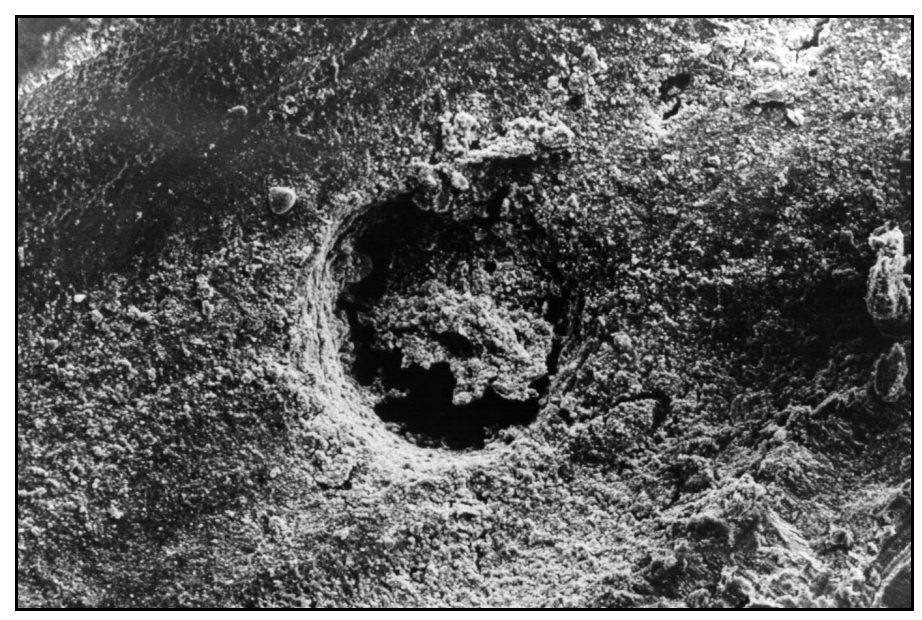

Figura 33- Embocadura de um canal lateral artificial no terço apical com obliteração parcial. Aumento de $150 \mathrm{X}$.

A obliteração, que ocorreu, pelo menos parcialmente, em alguns casos, não foi suficiente para impedir totalmente a entrada do material obturador. A compressão exercida pelo compactador durante a obturação pela Técnica Híbrida de Tagger faz com que o material seja impulsionado contra as paredes dos canais e, conseqüentemente, forçado em direção aos canais laterais, obturando-os. Além disso, o cimento AH Plus, que foi utilizado, tem um escoamento um tanto elevado e, devido a essa propriedade pode penetrar, mesmo nas pequenas frestas que poderiam existir quando da obliteração parcial proporcionada pela "smear layer". É interessante salientar que durante a realização da obturação dos canais a grande maioria dos canais laterais apresentou extravasamento de guta-percha e cimento obturador, esse em maior proporção.

Em relação às características das paredes dentinárias, pela análise descritiva das fotomicrografias pode-se observar diferenças entre os grupos e os terços.

No Grupo 1, onde foi usado apenas o EDTA, após a instrumentação, os resultados estão de acordo com aqueles encontrados por muitos autores que têm demonstrado a sua eficiência nos terços cervical e médio, 
e a sua má atuação no terço apical, deixando restos de "smear layer" 3, 28, 35, 90, 105. (Fig. 17 e 18)

No Grupo 2 não foi usado o EDTA, usourse apenas o laser de Nd:YAG, para que fossem analisadas as características da "smear layer" após a aplicação do laser.

Como era previsto, observa-se uma grande quantidade de "smear layer" nas paredes dentinárias (Fig. 19, 20, 21, 22, 23 e 24), independentemente do terço. A "smear layer" apresenta características diversas, existem algumas áreas onde ela parece ter sofrido fusão e ficou aderida às paredes, obliterando os túbulos dentinários (Fig. 20, 22 e 24), isto está de acordo com os resultados encontrados por ANIC et al. ${ }^{5}$, DEDERICH; ZAKARIASEN; TULIP $^{25}$, TURKMEN et al. ${ }^{92}$ e ZHANG et al. ${ }^{104}$.

Embora não se tenha observado interferência da "smear layer" na obturação dos canais laterais, neste trabalho, existem algumas controvérsias quanto à necessidade ou não da sua remoção. Alguns autores acreditam que ela seja útil, servindo como barreira contra a penetração de bactérias. $^{29}$ Outros, com os quais concordamos, são de opinião de que a sua presença é prejudicial. Ela é composta de uma camada formada por raspas de dentina e material orgânico que, muitas vezes, principalmente em casos de necrose, está contaminada por bactérias. Além disso, a "smear layer" dificulta a ação antimicrobiana dos agentes irrigantes no interior dos túbulos dentinários ${ }^{9,41,}$ 101, dos curativos de demora ${ }^{41,101,9}$,e atua como barreira física interferindo na

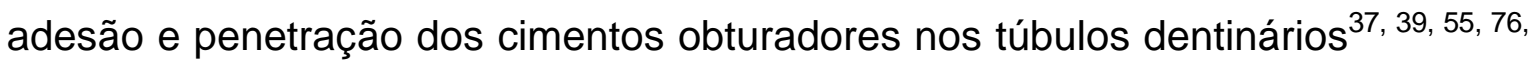
98.

No Grupo 3 pôde-se observar a ação do laser diretamente na parede dentinária, uma vez que se removeu a "smear layer" previamente pela ação do EDTA, o que não aconteceu no Grupo 2 onde a ação do laser atingiu a "smear layer" e a parede dentinária.

As figuras 26, 28 e 30 são referentes aos terços cervical, médio e apical, respectivamente, de um dente claro, onde não se observa, praticamente nenhuma ação do laser, apenas do EDTA. Esses resultados estão 
de acordo com os de BACHALL et al. ${ }^{7}$, que, após aplicação do laser de Nd:YAG dentro dos canais radiculares, não observaram selamento dos túbulos dentinários. Atribuíram este fato às características ópticas do laser.

Quando foi realizado a aplicação do laser de Nd:YAG com os mesmos parâmetros utilizados neste trabalho em um dente escuro, as características da parede dentinária mudou completamente como se pode observar nas figuras 34 e 35.

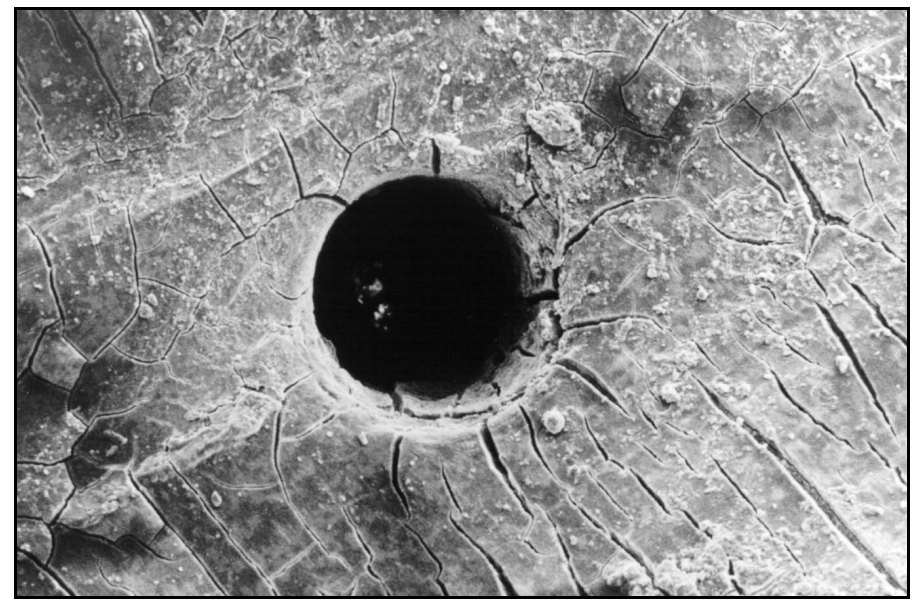

Figura 34- Embocadura de um canal lateral artificial no terço médio. Dente escuro pertencente ao Grupo 3. Aumento de150 X

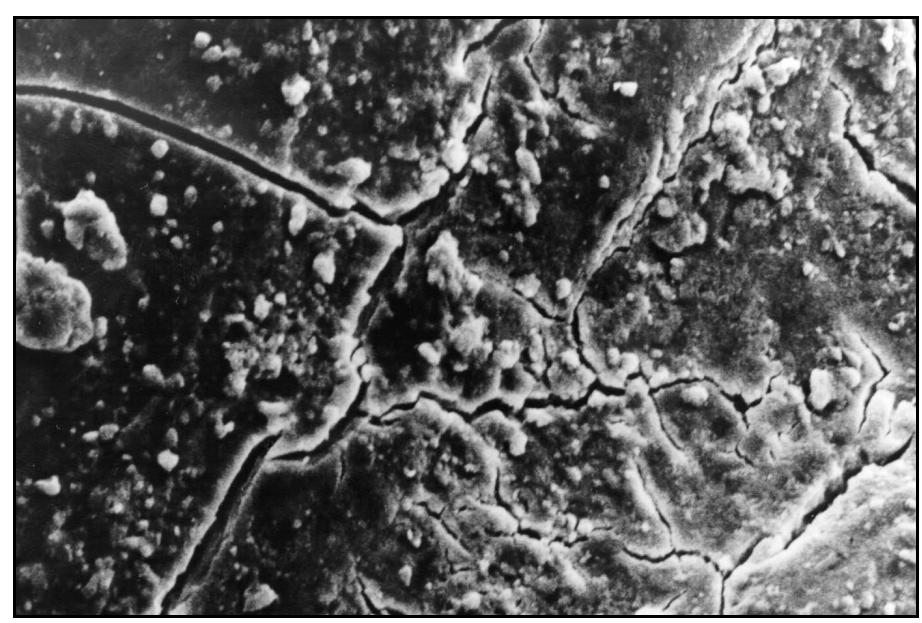

Figura 35- Parte de uma parede dentinária localizada no terço médio. Dente escuro pertencente ao Grupo 3. Aumento de 1000 X. 
A melhor absorção do laser de Nd:YAG acontece em tecidos pigmentados ${ }^{31,58}$. Devido a essa propriedade autores como GOYA et al. ${ }^{44}$ e ZHANG et al. ${ }^{104}$, antes da aplicação do laser de Nd:YAG pintaram a parede interna do canal com tinta preta. Isto potencializou em muito, a ação do laser. Todavia, não parece ser de aplicação viável na rotina endodôntica já que ficaria muito difícil de se remover toda a tinta que ficou aderida às paredes do canal e deixá-lo limpo novamente.

A alteração na parede dentinária com selamento dos túbulos dentinários é vista como uma vantagem, pois auxilia no selamento apical da obturação ${ }^{40}$ 44, 53, 80, 92. Para outros autores como BAHCALL et al. ${ }^{7}$, SAUNDERS et al. ${ }^{85}$, BEZERRA; ARAKI; CALDEIRA ${ }^{11}$, o laser de Nd:YAG não tem uma ação considerável nas paredes dos canais radiculares. BASSILL $\beta$ encontrou melhor selamento apical em obturações de canais, cujas paredes foram tratadas com laser de Nd:YAG antes da obturação, independentemente do cimento obturador utilizado.

Essa propriedade de selar túbulos dentinários, além de ser vantajosa no selamento apical, também auxilia no tratamento da hipersensibilidade, obliterando a grande maioria de túbulos dentinários expostos, e nas terapias periodontais ${ }^{54,60,63,72}$. Nesses procedimentos a ação do laser é melhorada, pois a posição da fibra óptica é perpendicular à parede dentinária no momento da aplicação do laser ${ }^{5,63}$. Dentro do canal, como aconteceu neste trabalho, a fibra óptica é posicionada de forma paralela à parede dentinária e, mesmo com os movimentos helicoidais, o feixe de laser pode não atingir algumas partes da parede dentinária, uma vez que o raio laser é unidirecional.

A ação do laser não se restringe apenas à parte estrutural da dentina, ele também tem um certo poder antibacteriano. ${ }^{34,48,51,73}$. A redução da quantidade de bactérias depende da energia de radiação e da espécie da bactéria presente ${ }^{34}$. 
Muitas vantagens são proporcionadas pelo laser de $\mathrm{Nd}: Y A G$, mas desvantagens existem e devem ser relatadas. Além do aumento da temperatura que pode levar células do ligamento periodontal à necrose e à formação de uma anquilose ${ }^{6}$ e também à desestruturação ch camada de células odontoblásticas $^{99}$, como já foi citado, o laser proporciona uma mudança química na estrutura dentinária. Nos canais onde foi aplicado laser e que foram utilizados para observação ao M.E.V., após a exposição das paredes dentinárias pelo seccionamento longitudinal das raízes, pode-se observar visualmente um aspecto mais ressecado e quebradiço da dentina. WHITE et al. ${ }^{97}$ descreveram que, após a aplicação do laser de Nd:YAG, há uma mudança na composição química do colágeno da matriz dentinária e, conseqüentemente, um aumento na parte mineral (fosfato de cálcio). Nos espécimes citados, observourse uma grande friabilidade da dentina parietal.

MAILLET; TORNECK; FRIEDMAN ${ }^{65}$ implantaram pedaços de dentina cortada com brocas e com laser, em subcutâneo de coelho e avaliaram a reação inflamatória. Aquelas que foram cortadas com laser apresentaram uma resposta inflamatória maior. Os autores explicaram dizendo que existe uma modificação no conteúdo protêico da dentina.

Finalizando, há que se concordar com FRENTZEN; $\mathrm{KOORT}^{38}$ que afirmaram que o laser mostra-se muito interessante e com grandes possibilidades, mas ainda existe um longo caminho de desenvolvimento. Apesar de não interferir na obturação de canais laterais e ter propriedades que melhore o selamento apical e poder antibacteriano, não é aconselhado adquirir esse tipo de laser, apenas para o uso exclusivo na Endodontia, pois, existem técnicas endodônticas e curativos de demora que, quando bem aplicados, podem substituir o uso desse tipo de laser, de custo, ainda, exageradamente alto. 
7-Conclusões 


\section{7-Conclusões}

Considerando as características específicas da realização e a metodologia utilizada neste trabalho, pode-se concluir:

1. Não foram encontradas diferenças significativas na ocorrência ou não de obturação dos canais laterais artificiais após o tratamento das paredes dos canais com EDTA, com laser de Nd:YAG ou com associação de ambos.

2. As fotomicrografias mostraram que as embocaduras dos canais laterais não foram obliteradas por dentina derretida, mas sim, em alguns casos pela própria "smear layer" formada durante o preparo dos canais.

3. Quanto à limpeza das paredes dentinárias, percebe-se que houve diferenças entre os grupos e os terços:

- Grupo 1 - Os terços cervical e médio apresentaram-se limpos com túbulos dentinários expostos. No terço apical notourse presença de "smear layer".

- Grupo 2 - Em todos os terços notou-se a presença de "smear layer" derretida e aderida às paredes.

- Grupo 3 - Nos dentes claros as características eram idênticas às do Grupo 1 e não se observou a ação do laser. No dente escuro se observou a ação do laser e uma completa obliteração dos túbulos dentinários. 
Referências Bibliográficas 


\section{Referências bibliográficas: ${ }^{*}$}

1

2
ADRIAN, J. C.; BERNIER, J. L.; SPRANGE, W. G. Laser and the dental pulp. J. Amer. dent. Ass., v. 83, n. 1, p. 113-7, July 1971. AKTENER, B. O.; BILKAY, U. Smear layer removal with different concentrations of EDTA - ethylenediamine mixtures J. Endod., v. 19, n. 5, p. 228-31, May 1993.

AMORIM, C. V. G.; LAGE - MARQUES, J. L. Avaliação comparativa da permeabilidade dentinária após o preparo do canal variando as substâncias químicas. Pesq. Odont. Bras., v. 15, p. 79, 2001. Suplemento. Abst. A069. /Trabalho apresentado na $18^{\circ}$ Reunião Anual do SBPqO, Águas de Lindóia, 2001/

ANIC, I. Et al. Permeability morphologic and temperature changes of canal dentine walls induced by Nd:YAG, $\mathrm{CO}_{2}$ and Argon laser. Int. Endod. J., v. 29, n. 1, p. 13-22, Jan. 1996.

ANIC, I. et al. Scanning electron microscopic study of dentin lased with argon, $\mathrm{CO}_{2}$ and Nd:YAG laser. J. Endod., v. 24, n. 2, p. 78-81, Feb. 1998.

BAHCALL, J. et al. Preliminary investigation of the histologycal effects of laser endodontic treatment on the periradicular tissues in dogs. J. Endod., v. 18, n. 2, p. 47-51, Feb. 1992.

* Normas recomendadas para uso no âmbito da Universidade de São Paulo, com base no documento "Referências Bibliográficas: exemplos", emanado do Conselho Supervisor do Sistema Integrado de Bibliotecas da USP, em reunião de 20 de setembro de 1990. 
BAHCALL, J. K. et al. Scanning microscopic comparison of canal preparation with Nd:YAG and hand instrumentation: a preliminary study. Gen. Dent., v. 41, n. 1, p. 45-7, Jan./Feb. 1993.

BASSILI, L. O. Infiltração apical em obturações de canais realizadas com dois tipos de cimento após a aplicação do laser Nd:YAG ou solução de EDTA nas paredes do canal radicular. Bauru, 2002. 75 p. Dissertação (Mestrado) - Faculdade de Odontologia de Bauru, Universidade de São Paulo.

BAUMGARTNER, J. C.; MADER, C. L. A scanning electron microscopic evaluation of four root canal irrigation regimens. $\mathbf{J}$. Endod., v. 13, n. 4, p. 147-57, Apr. 1987.

BEHREND, G. D.; CUTLER, C. W.; GUTMANN, J. L. An vitro study of smear layer removal and microbial leakage along root canal fillings. Int. Endod. J., v. 29, n. 2, p. 99-107, Mar. 1996. BEZERRA, A. G.; ARAKI, A.T.; CALDEIRA, C.L. Sealamento marginal apical de canais irradiados com Er e $\mathrm{Nd}$ e obturados com AHPlus. Pesq. Odont. Bras., v. 15, p. 99, 2001. Suplemento. Abst. A232. /Trabalho apresentado na $18^{\circ}$ Reunião Anual do SBPqO, Águas de Lindóia, 2001/ BRAMANTE, C. M. et al. Estudo comparativo de algumas técnicas de obturação de canais radiculares. Rev. bras. Odont., v. 46, n. 5, p. 26-35, set./out. 1989. 
lesões periodontais. Odont. Med., v. 13, n. 3, p. 25-9, abr. 1986.

Odontologia. São Paulo Pancast, , 1991.

CALERÓ, F. D. S. et al. Ação química do EDTA sobre a dentina do canal radicular - análise com espectrofotometria de absorção atômica. Rev. FOB, v. 5, n. 3/4, p. 65-8, jul./dez. 1997.

CALLAHAN, J. R. Rosin solution for the sealing of the dentinal tubule and as an adjunvant in the filling of root canals. Allied dent. Soc., v. 9 , p. $53-63,1914$.

CALLAHAN, J. R. Sulfuric acid for openning root-canals. Dent. Cosmos, v. 36, n. 12, p. 957-9, December 1894 apud ZUOLO, M. et al. Ação do EDTA e suas associações com tensoativos na permeabilidade da dentina radicular. Rev. Odont. USP, v. 1, n. 4, p. 18-23, out./dez. 1987.

ÇALT, S.; SEPER, A. Smear layer removal by EDTAG J. Endod., v. 26, n. 8, p. 459-61, Aug. 2000.

ÇALT, S.; SEPER, A. Time-dependent effects of EDTA on dentin structures. J. Endod., v. 28, n. 1, p. 17-9, Jan. 2002.

CARDOSO, L. N., TORRES, E. C. B., PROKOPOWITSCH, I. Avaliação de três substâncias químicas auxiliares na remoção de $\mathrm{Ca}(\mathrm{OH})_{2}$ dos canais radiculares Pesq. Odont. Bras., v. 15, p. 75 , 2001. Suplemento. Abst. A036. /Trabalho apresentado na $18^{\circ}$ Reunião Anual do SBPqO, Águas de Lindóia, 2001/ 
CENGIZ, T.; AKTENER, B. O.; PISKIN, B. The effect of dentinal tubule orientation on the removal of smear layer by root canal irrigants. A scanning electron microscopic study. J. Endod., v. 23, n. 3, p. 16371, May 1990.

CIUCCHI, B.; KHETTABI, M.; HOLZ, J. The effectiveness of different endodontics irrigation procedures the removal of a smear layer: a scanning electron microscopic study. Int. Endod. J., v. 22, n. 1, p. 21-8, Jan. 1989.

COHEN, S.; BURNS, R. C. Caminhos da polpa. 7. ed. Rio de Janeiro, Guanabara Koogan, 1998.

DAMETTO, F. R. et al. Análise comparativa da remoção da "smear layer" dos canais radiculares - microscopia eletrônica de varredura. Pesq. Odont. Bras., v. 15, p. 134, 2001. Suplemento. Abst. B036. /Trabalho apresentado na $18^{\circ}$ Reunião Anual do SBPqO, Águas de Lindóia, 2001/.

DEDERICH, D. N.; ZAKARIASEN, K. L.; TULIP, J. Scanning electron microscopic analysis of canal wall dentin following NeodymiumYttrium-Aluminum-Garnet laser irradiation. J. Endod., v. 10, n. 9, p. 428-31, Sept. 1984.

DE DEUS, Q. D. Frequency, location and direction of the lateral, secondary and accessory canals. J. Endod., v. 1, n.11, p. 361-6, Nov. 1975. 
DIEP, E. K.; BRAMANTE, C. M. Efeito do modo de aplicação do EDTA na limpeza das paredes dos canais radiculares. Rev. FOB, v. 5, n.1/2, p. 1-7, jan./jun. 1997 .

DRAKE, D. R. et al. Bacterial retention in canal walls in vitro: effect of smear layer. J. Endod., v. 20, n. 2, p. 78-82, Feb. 1994.

DUARTE, M. A. H. Avaliação de algumas propriedades físico químicas do cimento AH Plus puro e acrescido de hidróxido de cálcio. Bauru, 1999. Tese (Doutorado) - Faculdade de Odontologia de Bauru, Universidade de São Paulo. EDUARDO, C. P.; GOUW-SOARES, S; HAYPEK, P. Utilização clínica dos lasers In: CARDOSO, R. J. A.; GOLÇALVES, E. A. N. Odontologia: dentística e laser. São Paulo, Artes médicas. 2002. Cap. 23, p. 441-61./Apresentado no $20^{\circ} \mathrm{CIOSP}$. FEHR, F. R.; OSTBY, B. N. Effect of EDTAC and sulfuric acid on root canal dentine. Oral Surg., v. 16, n. 2, p. 199-205, Feb. 1963.

FERRAZ, C. C. R. Influência da smear layer no tratamento endodôntico. ASSENDO Informativo, p.8, set./dez. 2002. FOLWACZNY, M. et al. Antibacterial effects of pulsed Nd:YAG laser irradiation at different energy setting in root canals. J. Endod., v. 28, n. 1, p. 24-9, Jan. 2002.

FRASER, J. G. Chelating agents: Their softening effect on root canal dentin. Oral Surg., v. 37, n. 5, p. 803-11, May 1974. 
the Nd:YAG dental laser. Angle Orthodont., v. 63, n. 4, p. 299-303, Apr. 1993.

FREITAS, L. F. et al. Avaliação da técnica híbrida de Tagger em presença e ausência de "smear layer". Pesq. Odont. Bras., v. 15, p. 137, 2001. Suplemento. Abst. B059. /Trabalho apresentado na 18 reunião Anual do SBPqO, Águas de Lindóia, 2001/.

FRENTZEN, M.; KOORT, H. J. Lasers in dentistry: new possibilities with advancing laser technology? Int. dent. J., v. 40, n. 6, p. 323-32, Dec. 1990.

GENTTLEMAN, B. H.; MESSER, H. H.; ELDEEB, M.E. Adhesion of sealer cements to dentin with and without the smear layer. $\mathbf{J}$. Endod., v. 17, n. 1, p. 15-20, Jan. 1991.

GOODIS, H. E. et al. Scanning electron microscopic examination of intracanal wall dentin: hand versus laser treatment. Scanning Micros., v. 7, n. 3, p. 979-87, Sept. 1993. GOLDBERG, F.; ABRAMOVICH, A. Analysis of the effect of EDTAC on the dentinal walls of the root canal. J. Endod., v. 3, n. 3, p. 101 5, Mar. 1977.

GOlDBERG, F.; ARTAZA, L. P.; DE SILVIO, A. C. Effectiveness of different obturation techniques in the filling of simulated lateral canal. J. Endod., v. 27, n. 5, p. 362-4, May 2001.

GOLDBERG, F.; ARTAZA, L. P.; DE SILVIO, A. C. Influence of calcium hydroxide dressing on the obturation of simulated lateral 
canals. J. Endod., v. 28, n. 2, p. 99-101, Feb. 2002.

GOYA, C. et al. Effects of pulsed Nd:YAG laser irradiation on smear layer at the apical stop and apical leakage obturation Int. Endod. J., v. 33, n. 3, p. 266-71, May 2000.

GROSSMAN, L. I.; MEIMAN, B. W. Solution of pulp tissue by chemical agents. J. Amer. dent. Ass., v. 28, n. 2, p. 223-5, 1941 apud LEONARDO, M. R. Preparo biomecânico dos canais radiculares: definição, conceituação, finalidade, importância, recursos para sua aplicação e meios químicos (soluções irrigadoras). In:LEANARDO, M. R.; LEAL, J. M. Endodontia: tratamento de canais radiculares. 3. ed., São Paulo, Panamericana, 1998. Cap. 15 , p. 333-58

GROSSMAN, L. I.; SHEPARD, L.I.; PEARSON, L. A. Roentgenologic and clinical evaluation of endodontically treated teeth. Oral Surg., v. 17, p. 368-74, Mar. 1964.

GUTIERREZ, J. H. et al. The risk intentional dissolution of the smear layer after mechanical preparation of root canals. Oral. Surg., v. 70, n. 1, p. 96-108, July 1990.

GUTKNECHT, N. et al. Bactericidal effect of the Nd:YAG laser in vitro root canals. J. Clin. Laser Med. Surg., v. 14, n. 2, p. 77-80, Apr. 1996.

GUTKNECHT, N. et al. Long - term clinical evaluation of endodontically treated teeth by Nd:YAG lasers. J. Clin. Laser Med. Surg., v. 14, 
n. 1, p. 77-80, Jan. 1996 .

HAAPASALO, M.; ORSTAVIK, D. In vitro infection and disinfection of dentinal tubules. J. dent. Res., v. 66, n. 8, p. 1375-9, Aug. 1987. HARDEE, M. W. et al. Evaluation of the antibacterial effects of intracanal Nd:YAG laser irradiation. J. Endod., v. 20, n. 8, p. 37780, Aug. 1994.

HECHI, J. Neodymium laser. In: HECHI, J. The laser guidebook, 2. ed. , New York, McGraw - Hill, 1992. Cap. 22, p. 389-417.

KHAYAT, A. et al Scanning electron microscopic study of resect teeth using Nd:YAG laser. J. Endod., v. 17, n. 4, p. 196, Apr. 1991./ Abst. 39/

KIMURA, Y.; WILDER - SMITH, P.; MATSUMOTO, K. Lasers in endodontics: a review. Int. Endod. J., v. 33, n. 3, p. 173-85, May 2000.

KÜÇÜKAY, I. K.; BYIRLI, G. An apical leakage study in the presence and absence of the smear layer. Int. dent. J., v. 27 , n. 2, p. 87-93, Mar. 1994.

KUGA, M. C. et al. Constancia do limite apical da obturação de canais radiculares em função das técnicas de Tagger et al. e de Nguyen. Rev. bras. Odont., v. 46, n. 5, p. 2-8, set./out. 1989. KUTLLER, Y. Endodoncia prática. México, Alpha, 1961. KUTSCH, V. K. Laser in dentistry:comparing wavelengths. J. Amer. dent. Ass, v. 124, n. 2, p. 49-54, Feb. 1993. 
LAN, W. H. Temperature elevation on the root surface during Nd:YAG laser irridiation in the root canal. J. Endod., v. 25, n. 3, p. 155-6, Mar. 1999.

60

LAN, W. H.; LIU, H. C.; LIN, C. P. The combined occluding effect of sodium fluoride varnish and Nd:YAG laser irradiation on human dentinal tubules. J. Endod., v. 25, n. 6, p. 424-6, June 1999.

LEONARDO, M. R.; LEAL, J. M. Endodontia: tratamento de canais radiculares. 3. ed. São Paulo, Panamericana, 1998.

LEVY, G. Cleaning and shaping the root canal with a Nd:YAG laser beam: a comparative study. J. Endod., v. 18, n. 3, p. 123-7, Mar. 1992.

LIU, H.C.; LIN, C. P.; LAN, W. H. Sealing depth of Nd:YAG laser on human dentinal tubules. J. Endod., v. 23, n. 11, p. 691-3, Nov. 1997.

LOVE, R. M. Regional variation in root dentinal tubule infection by Streptococcus gordonii. J. Endod., v. 22, n. 6, p. 290-3, June 1996.

MAILLET, W. A; TORNECK, C. D.; FRIEDMAN, S. Connective tissue response to root surfaces resected with Nd:YAG laser or burs. Oral Surg., v. 82, n. 6, p. 681-90, Dec. 1996.

MC SPADDEN, J. T. Obturation of the radicular space. In: INGLE, J. I.; BAKLAND, L. K. Endodontics 4. ed. Baltimore, Wilians \& Wilkins, 1994. 
Ed. Santos, 2001.

MISERENDINO, L.J. et al. Histologic effects of a thermally cooled Nd:YAG laser on the dental pulp and supporting structures of rabbit teeth. Oral Surg., v. 76, n. 3, p. 93-100, July 1994.

MISERENDINO, L. J.; LEVY, G.; RIZOIU, I. M. Efects of Nd:YAG laser on the permeability of root canal wall dentin. J. Endod., v. 21, n. 2, p. 83-7, Feb. 1995.

MORAES, I. G. Infiltração marginal nas obturações de canais radiculares em função de agentes irrigadores e cimentos obturadores. Bauru, 1981. 114p. Dissertação (Mestrado) Faculdade de Odontologia de Bauru, Universidade de São Paulo. MORAES, I. G. et al. Técnicas híbridas de obturação de canais radiculares. Rev.Gaúcha.Odont., v. 37, n. 4, p. 266-8, jul./ago. 1989.

MORLOCK, B. J. et al. The effect of Nd:YAG laser exposure on root surfaces when used as an adjunct to root planning: an in vitro study. J. Periodont, v. 63, n. 7, p. 637-41, July 1992. MOSHONOV, J. et al. Nd:YAG laser irradiation in root canal disinfection. Endod. dent. Traumat., v. 11, n. 5, p. 220-4, Oct. 1995.

NAIR, P. N. R. Light and electron microscopic studies of root canal flora and periapical lesions. J. Endod., v. 13, n. 1, p. 29-39, Jan. 1987. 
organic chelating agents at neutral pH. J. dent. Res., v. 32, n. 6, p. 859-67, Dec. 1953.

OKSAN, T. et al. The penetration of root canal sealers into dentinal tubules. A scanning electron microscopic study. Int. Endod. J., v. 26, n. 5, p. 301-5, Sept. 1993.

OLIVEIRA, D. P. et al. Estudo comparativo da limpeza das paredes dos canais radiculares. Pesq. Odont. Bras., v. 15, p. 79, 2001. Suplemento. Abst. A070. /Trabalho apresentado na $18^{\circ}$ Reunião Anual do SBPqO, Águas de Lindóia, 2001/. ORTEGA, R. M. et al. Obturação de canais laterais artificiais por diferentes cimentos endodônticos. Pesq. Odont. Bras., v. 15, p. 57, 2001. Suplemento. Abst. I283. /Trabalho apresentado na $18^{\circ}$ Reunião Anual do SBPqO, Águas de Lindóia, 2001/. OSTBY, B. N. Chelation in root canal therapy. Odont. T., v.65, p.3-11, 1957.

PARK, D. S. et al. Effects of Nd:YAG laser irradiation on the apical leakage of obturaded root canals: an electro-chemical study. Int. Endod. J., v. 34, n. 4, p. 318-21, June 2001. PÉREZ, V. C. et al. The possible role of $\mathrm{pH}$ changes during EDTA desmineration on of teeth. Oral Surg., v. 68, n. 2, p. 220-2, Aug. 1989. Médico/Quirurgica, 1944. v. 1. 
RIBEIRO, F. C.; CONSOLARO, A. Bactérias nas estruturas mineralizadas de dentes com necrose pulpar e granuloma apical. Rev. Dent. Press de Biologia Oral, v.1, n.1, p. 17-30, jan./abr. 2000. RIBEIRO, G. G.; MEDINA, J.; MORAES, I.G. Soluções irrigadoras versus selamento apical de obturações de canais radiculares. Pesq. Odont. Bras., v. 15, p. 138, 2001. Suplemento. Abst. B061. /Trabalho apresentado na $18^{\circ}$ Reunião Anual do SBPqO, Águas de Lindóia, 2001/

SAUNDERS, W. P. et al. The effect of an Nd:YAG pulsed laser on the cleaning of the root canal and the formation of a fused apical plug. Int. Endod. J., v. 28, n. 4, p. 213-20, July 1995. SCHILDER, H. Filling root canals in three dimensions. Dent. Clin. N. Amer., p. 723-44, Nov. 1967.

STABHOLZ, A. et al. Effects of Nd:YAG laser on apical seal of teeth after apicoectomy and retrofill. J. Endod., v. 18, n. 8, p. 371-5, Aug. 1992.

STABHOLZ, A. et al. Scanning electron microscopic study of the apical dentine surfaces lased with Nd:YAG following apicectomy and retrofill. Int. Endod. J., v. 25, n. 6, p. 288-91, Nov. 1992. TAGGER, M. Use of thermo-mechanical compactors as an adjunt to lateral condensation. Quintessence Int., v. 15, n. 1, p. 27-30, Jan. 1984. 
layer by three endodomtic irrigants and two types of laser. Int.

Endod. J., v. 32, n. 1, p. 32-9, Jan. 1999.

TAVANO, O.; ESTEVAM, E. A imagem radiológica In: ALVARES, L. C.; TAVANO, O. Curso de radiologia em odontologia 3. ed. São Paulo Ed. Santos 1998. Cap 2, p.17-40.

TÜRKMEN, C.; et al. Effect of $\mathrm{CO}_{2}, \mathrm{Nd}: \mathrm{YAG}$ and ArF Excimer lasers on dentin morphology and pulp chamber temperature: an in vitro study. J. Endod., v. 26, n. 11, p. 644-8, Nov. 2000.

VILLEGAS, J. C. et al. Obturation of accessory canals after four different final irrtigation regimes. J. Endod., v. 28, n. 7, p. 534-6, July 2002.

WEICHMAN, J. A.; JOHNSON, F. M.; NITTA, L. K. Laser use in endodontics part II. Oral Surg., v. 31, n. 5, p. 828-30, November 1972.

WEINE, F. S. The enigma of the lateral canal. Dent. Clin. North Amer. v. 28, n. 4, p. 833-52, Oct. 1984.

WHITE, J. M.; FARGAN, M. C.; GODDIS, H. E. Intrapulpal temperatures during pulsed Nd:YAG treatment of dentin, in vitro. J. Periodontal, v. 65, n. 3, p.255-9, Mar. 1994.

WHITE, J. M. et al. Identification of physical modification threshold of dentin induced by neodymium and holmium YAG lasers using scanning electron microscopy. Scanning Micros., v. 7, n. 1, p. 23946, Mar. 1993. 
WHITE, R. R.; GOLDMAN, M.; LIN, P. S. The influence of the smeared layer upon dentinal tubule penetration by plastic filling materials. J. Endod. v. 10, n. 12, p. 558-62, Dec. 1984.

WIGDOR, $\mathrm{H}$. et al. The effect of lasers on dental hard tissues. J. Amer. Dent. Ass., v. 124, n. 2, p. 65-70, Feb. 1993.

WOLCOTT, J. et al. Effect of two obturation techniques on the filling of lateral canals and the main canal. J. Endod., v. 23, n. 10, p. 632-5, Oct. 1997.

YAMADA, R. S. et al. A scanning microscopic comparison of a high volume final flush with several irrigating solutions. J. Endod., v. 9, n. 4, p. 137-42, Apr. 1983.

XU, G.; ZHANG, Z. Filling of the lateral canal. Oral Surg., v. 58, n. 2, p. 221-4, Aug. 1984.

ZAKARIASEN, K. L.; DEDERICH, D. N.; TULIP, J. $\mathrm{CO}_{2}$ and Nd:YAG laser fusion of dentin plugs in root canals. J. Endod., v. 10, n. 3, p. 145, 1985. /Abstrat 30/

ZHANG, C. et al. Effects of pulsed Nd:YAG laser irradiation on root canal wall dentin with different laser initiators J. Endod., v. 24, n. 5, p. 352-5, May 1998. ZUOLO, M. et al. Ação do EDTA e suas associações com tensoativos na permeabilidade da dentina radicular. Rev. Odont. USP, v. 1, n. 4, p. 18-23, out./dez. 1987. 
Abstract 


\section{A6stract:}

This study aimed at evaluating the influence of EDTA, $\mathrm{Nd}$ :YAG laser and the combination of both on the surface of the dentinal walls and for filling of artificial lateral root canals. Fifty-four single-rooted mandibular premolars with one canal were employed. Their crowns were removed and three artificial lateral root canals were prepared, one at each third of one proximal aspect of each root, by means of a reamer with a similar diameter to a $\mathrm{K}$ file \#15. After preparation of the lateral canals, the main canals were instrumented with $\mathrm{K}$ files up to \#40 at the apical portion and Gates Glidden burs at the middle and cervical thirds. Irrigation was performed with $1 \%$ sodium hypochloride every change of instrument, followed by final irrigation with saline solution. The teeth were divided in three groups with 18 roots each, according to the type of treatment applied to the canal walls: Group 1 - application of EDTA for 5 minutes, agitation with the working length file, and final irrigation with saline solution; Group 2 - four applications of $\mathrm{Nd}$ :YAG laser at $15 \mathrm{~Hz}, 100 \mathrm{~mJ}$ and 1.5 Watts with helicoidal movement in each tooth; and Group 3 - application of EDTA as described for group 1, finalizing with application of Nd:YAG laser as described for Group 2. Three roots were prepared for SEM analysis and the remaining 15 roots were obturated. Obturation was carried out with $\mathrm{AH}$ plus cement through Tagger's hybrid technique. Radiographs of the roots were then obtained in order to analyze the obturation of the artificial lateral canals. The roots employed for SEM analysis were longitudinally sectioned and prepared for the photomicrographs, in which an attempt was made to demonstrate the openings of the lateral canals and dentinal tubules. No statistically significant differences $(p<0.05)$ were observed between the performed procedures, neither for the independent analysis of each third regarding obturation of the artificial lateral canals. The photomicrographs revealed that the openings of the artificial lateral canals were obliterated by "smear layer" in some instances, and not by the dissolved dentin. Besides, in some cases the application of laser was unable to dissolve the dentin and seal the dentinal tubules. 
Apêndice 


\section{Universidade de São Paulo Faculdade de Odontologia de Bauru}

Al. Dr. Octávio Pinheiro Brisolla, 9-75 - Bauru-SP-CEP 17012-901 - C.P. 73

PABX (0XX14)235-8000 - FAX (0XX14)223-4679

Comite de Éfica em Pesquisa

Processo $n^{\circ} 083 / 2002$

Bauru, 30 de agosto de 2002

Senhor Professor,

O projeto de pesquisa encarninhado a este Comitê de Ética em Pesquisa em Seres Humanos, denominado "Influência do laser de Nd:YAG nas paredes dentinárias do canal radicular e na obturaçāo de canais laterais, em dentes extraídos", de autoria de Femanda Gomes de Moraes, que será desenvolvido sob sua orientaçăo, foi enviado ao relator para avaliaçāo.

$\mathrm{Na}$ reuniăo de 28 de agosto o parecer do relator, aprovando o projeto, foi aceito pelo Comitè, considerando que năo existem infrações éticas pendentes.

Informamos que após o envio do trabalho concluido, este Comitẽ enviará o parecer final, que será utilizado para publicaçăa do trabalho.

Atenciosamente,

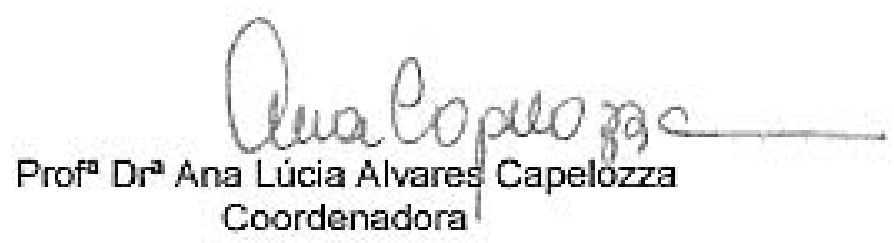

$\| \mathrm{m}^{\circ} \mathrm{Sr}$. Prof. Dr. Clovis Monteiro Bramante

DD. Docente do Departamento de Dentística, Endodontia e Materiais Dentários (Endodontia) 


\section{Universidade de São Paulo \\ Faculdade de Odontologia de Bauru}

Al. Dr. Octávio Pinheiro Brisolla, 9-75 - Bauru-SP-CEP 17012-901 - C.P. 73

PABX (0XX14)235-8000 - FAX (0XX14)223-4679

Conile de Etica em Pesquisa

\section{Processo No 083/2002}

Bauru, 11 de março de 2003

Senhor Professor,

Informamos que após anàlise por este Comitê de Etica em Pesquisa em Seres Humanos, seu pedido de alteração do titulo do projeto de pesquisa intitulado 'Influência do laser de Nd:YAG nas paredes dentinárias do canal radicular e na obturação de canais laterais, em dentes extraidos" de autoria da C.D. Fernanda Gomes de Moraes, sob a sua orientação, para "Influência do EDTA, laser de Nd:YAG e da associação de ambos sobre a dentina radicular e na obturaçāo de canais laterais", foi aprovado considerando que sua metodologia năo sofreu modificaçōes.

Sendo o que nos apresenta para o momento, despedimo-nos,

Atenciosamente,

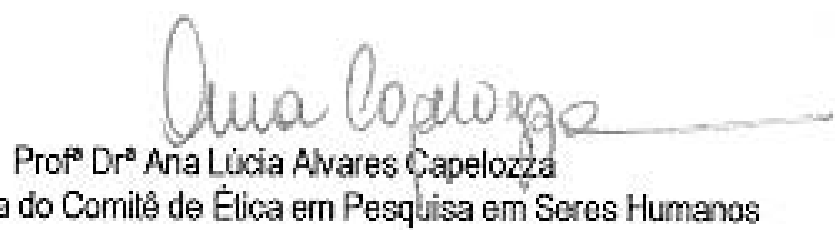

Ilm ${ }^{\circ}$ Sr. Prof. Dr. Clovis Monteiro Bramante

DD. Docente do Departamento de Dentistica, Endodontia e Materiais Dentärios 